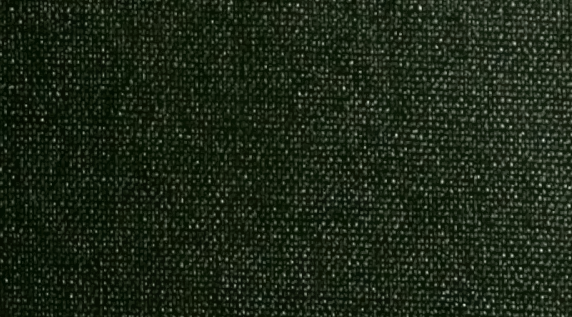

15.

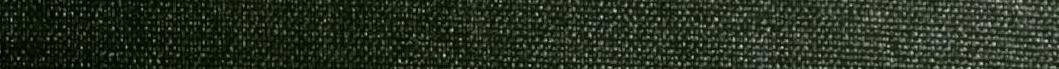
(2) 7. 
UNIVERSITY O

ILLINOIS LIBRARY

AT URBANA.CHAMPAIGN

NATURAL. HIST SURVEY 





\section{ILINOIS BIRDS: CORVIDAE}

Jean W. Graher, Richard R. Graber, and Ethelyn L. Kirk
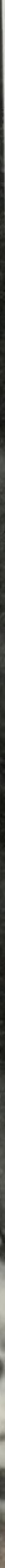


\section{Illinois Birds: Corvidae}

\section{Jean W. Graber, Richard R. Graber, and Ethelyn L. Kirk}

The crow family in Illinois is now represented by only three species that are regular residents-the wellknown blue jay and American crow and the relatively little-known (in Illinois) fish crow. Other species that have been recorded in the state-gray jay, scrub jay, Steller's jay, Clark's nutcracker, black-billed magpie, and common raven-are rare or accidental in Illinois.

Both the blue jay and the American crow are represented by at least three populations in Illinois: local breeders (birds hatched in Illinois that probably winter in Illinois or to the south and return to their natal areas to breed), birds that enter the state and probably pass through Illinois to their breeding and wintering areas, and birds that enter the state and stay through the winter. Some local breeders may migrate. The populations are not necessarily morphologically (genetically) distinct, and their biology is difficult to study. Studies of banded populations are particularly needed.

A notable characteristic of the Illinois Corvidae is their (strictly ?) diurnal migration. Our counts of these migrations were made anywhere we found them, but especially from high points along major rivers and streams, many of which have not been adequately checked for migration. The counts were of numbers of birds of each species passing (on all sides) our observation point per hour.

C.T. Black's (1941) extraordinary study of the crow in Illinois is unique for its biologic and geographic depth and breadth. We have cited it frequently, but serious students of the crow in this country should refer to his original paper.

\section{Acknowledgments}

As usual, many people helped with this paper. In the Illinois Natural History Survey we are especially indebted to Dr. Glen C. Sanderson, Head of the Wildlife Research Section, who edited the original

This paper, the eleventh in a series on the birds of Illinois, is published by authority of the State of Illinois. It is a contribution from the Section of Wildlife Research of the Illinois Natural History Survey. Dr. Jean W. Graber and Dr. Richard R. Graber were, until their retirement in 1983, Wildlife Specialists at the Survey. The late Miss Ethelyn L. Kirk served as a Technical Assistant.

The recommendations of two or more outside referees are required before a manuscript is accepted for publication in Biological Notes. manuscript as he has-to their great benefit-nearly all the papers in this series. Drs. Christopher D. Burnett and Scott K. Robinson reviewed the manuscript. Elizabeth Anderson prepared finished papers from our rough manuscripts, and Lloyd Le Mere completed finished drawings from our rough copies. Our extensive use of the Survey library always received generous help going back to Ruth Warrick and Doris Dodds and, most recently, Monica Lusk and Carla Heister. Frank Bellrose and Robert Crompton shared with us their extensive data on the blue jay migration in the Illinois valley. Many other colleagues in and out of the Survey gave us observations. We would especially like to mention James W. Seets and Charles Nixon of the Survey and Jared Garver of the Illinois Department of Conservation.

\section{GRAY JAY \\ (Perisoreus canadensis)}

There are no documented records of this northern and western species in Illinois, though it has been reported twice-once at Peoria in winter (Loucks 1892, see Bohlen 1978) and once at a Highland Park feeder in winter, 1958-1959 (Lehmann 1959; Mumford 1959; Russell 1967). One was captured at nearby Racine, Wisconsin, in winter, 1859 (Nelson 1876; Ford 1956). Reference to 149 gray jays at Hannibal, Missouri (A. Shaw and J. Shaw 1983), was obviously an error.

\section{SCRUB JAY \\ (Aphelocoma coerulescens)}

A scrub jay, its origin uncertain, was seen at Illinois Beach State Park from 29 September-30 October 1984 (Peterjohn 1985). This entry is out of phylogenetic sequence and would normally follow Cyanocitta.

\section{STELLER'S JAY (Cyanocitta stelleri)}

The three Illinois reports of Steller's jay, all from the Chicago area, may refer to escaped captives. Included were a specimen shot at Lincoln Park, 12 June 
1911, and subsequently identified as $C$. s. macrolopha (Woodruff 1912; Ford 1956) and another banded at Highland Park, where it was observed many times between Easter and Thanksgiving, 1952, and identified as C. s. annectens (Downing 1952). The third was seen 25 May 1965 at Palos Hills Forest Preserve (Bohlen 1978).

\section{BLUE JAY \\ (Cyanocitta cristata)}

\section{(Cover)}

\section{Spring Migration}

Although blue jays indisputably migrate in (through) Illinois (Fig.1), many questions about the phenomenon-precise routes, annual variation, percentage of population involved, age and sex composition of the migrant swarm, physical and food factors that influence migration-need special study. The state is never without jays (Fig. 2 and 3). The origin of winter birds and migrants appears to be from the north-northeast (Fig. 4).

The available data indicate that the migration of jays is strictly diurnal; however, the difficulty of distinguishing true long-distance migration from local flights to foraging and roosting sites can produce inaccuracies in the data. Widmann (1907) pointed out that the migration is not restricted to the vicinity of such striking landmarks as shorelines and floodplains but has been reported especially from such places (Buck 1981; Kleen 1974a). Jay migration on a broad front has not been reported, nor has high altitude $(>1,000 \mathrm{ft}=305 \mathrm{~m})$ migration of jays been observed, but these should be looked for. High altitude migration, especially, would be easily overlooked. Crosscountry migration of jays appears similar to migration along shorelines-one jay, or more typically a flock of jays, following with little variation the line of flight of the last jays that passed. Sometimes the "line" may spread as wide as $1 \mathrm{~km}$, possibly in response to the birds' sighting of the observer or when especially large numbers of birds are involved. Bellrose (1972) map-

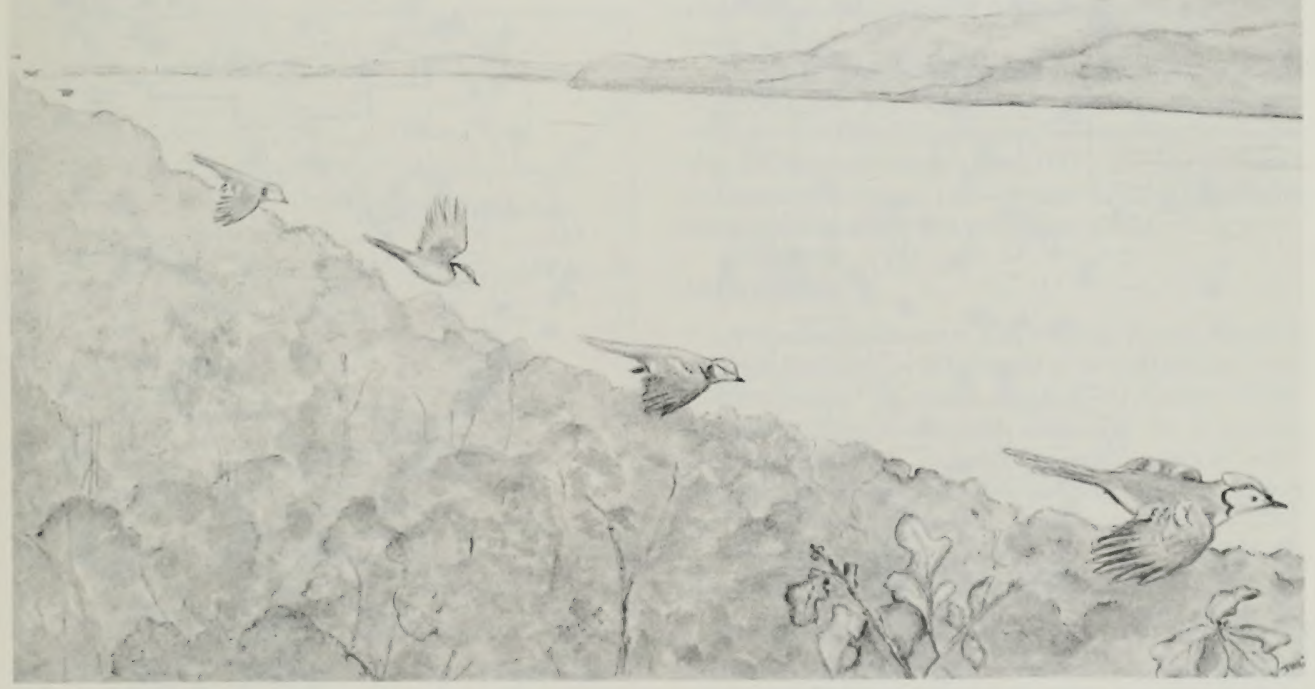

Fig. 1.-A sketch of blue jays migrating along the Ohio River, where numbers are generally not as high as those found along the Illinois and Mississippi rivers. Migrating jays typically pass a given point in pulses-a flock of 5-75 birds associated in a loose string followed by a pause of 5-20 minutes before the next string appears. Regardless of the interval between these pulses, one string follows the path of its predecessor as if the preceding string could still be seen, an unlikely circumstance in many cases. 
ped the blue jay migration route along the Illinois valley and found the width of the flight path in many places to be no more than $90 \mathrm{~m}$ during at least 6 years of observations. Jays usually fly less than $500 \mathrm{ft}$ (152 $\mathrm{m}$ ) above local terrain, often just above the treetops. They are generally silent but become vociferous when they pause in treetops, as they sometimes do. Migratory behavior varies considerably for reasons unknown to us (population? locality? age? sex?). We have observed migrations under clear as well as under overcast skies and before and after frontal passages. We have not seen migrations when winds were much over $10 \mathrm{mph}$. Most often, large flights begin within an hour after dawn and last until about 1100 CST. Migration may resume, especially after 1500 , ending before

\section{Blue Jay}

\section{Breeding Records}

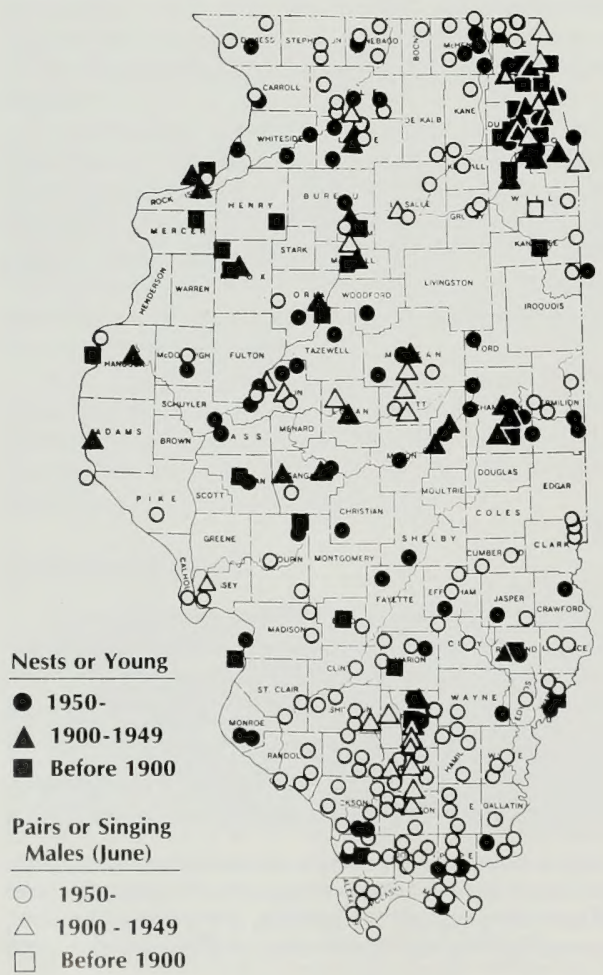

Fig. 2.-Breeding records of the blue jay in Illinois. dark. There is no evidence that it continues into the night. Jays pass a given point in pulses-a series of flocks (typically $5-75$ birds per flock associated in a loose string) passing, followed by a pause of 5-20 min before the next series appears. Notwithstanding the interval between pulses, one series of flocks follows the path of the last, as if the last flock could still be seen ahead (unlikely in many cases). Although this pattern is perplexing, it is always noticeable in any large migration of jays. We sometimes have seen what we believe to be low-volume migrations of only a few birds per hour flying traditional paths in the appropriate direction. The general behavior of these birds is the same as the behavior of birds in larger migrations, but the intervals between pulses are much

\section{Blue Jay}

Winter Records

Dec. 15-Feb. 1

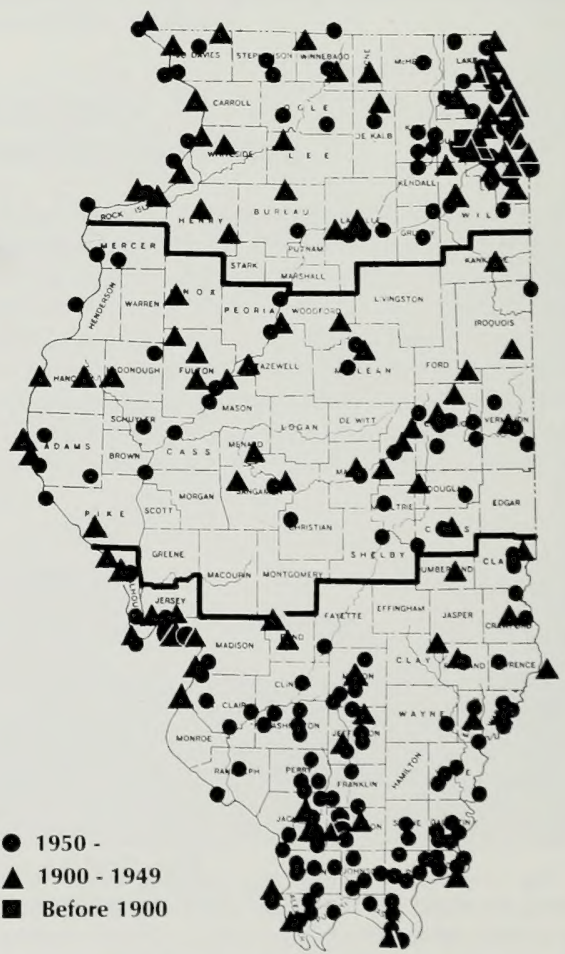

Fig. 3.-Winter records of the blue jay in Illinois. Heavy horizontal lines indicate the three regions of the state (north, central, and south) referred to in the text. 
longer. Our only measurement of flight speed was made by driving parallel to a flock and matching car speed to flock speed. We recorded a speed of more than 25 but less than $30 \mathrm{mph}$, a reading that included a nearly direct tail wind of $5 \mathrm{mph}$. We therefore estimated a ground speed of about $23 \mathrm{mph}$.

There are differences in the jays' migration routes between spring and fall. In the south we saw more cross-country migration (migration away from rivers) in spring than in fall, but Bellrose (1972) believed the overall number of routes to be greater in fall. Much field work is needed to determine all the routes used by jays in Illinois. A number of species use the same routes and are often seen flying at the same times as jays, but this phenomenon appears to occur more frequently in fall. Jay migration has been observed as early as 14 March in southern Illinois and as early as 17 March in the central region (M. Campbell, unpublished 1971). High numbers of migrating jays were seen 18 April-2 May in southern Illinois $(55-700 / \mathrm{hr}$, cross-country), 22-30 April in the central region $(100-800 / \mathrm{hr}$, in the Illinois valley), and 1-21 May in the north $(100 / \mathrm{hr}-650+$ /period? on the Lake Michigan shore [Fawks 1966]). The highest counts of

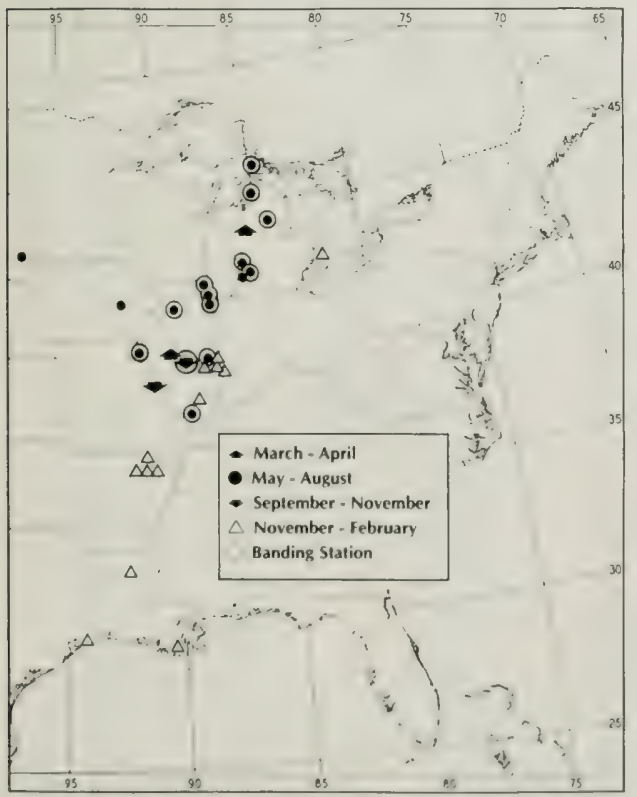

Fig. 4.-Recoveries (symbols only) and banding locations (symbols enclosed by circles) of blue jays that were either banded or recovered in lllinois. "foraging" (nonmigrating) jays did not coincide exactly with the peak migration days (Fig. 5). High counts of "foraging" jays were made 14 March-22 April in the south ( $36-50$ birds counted per day), 15 April-17 May in the central region (40-70/day), and 18 April-12 May in the north (22-38/day). No counts of foraging jays are available for the Lake Michigan area.

The latest dates on which active migrations of jays have been seen in Illinois were 26 May in the south, 14 May in the central region, and 21 May in the north. Migrations may occasionally extend into June (Peterjohn 1983) and should be looked for both earlier and later than our observations show.

The censuses (Table 1) are measures of foraging birds and exclude actively migrating jays. Spring densities of jays, as usual, were high in forest-edge and shrub habitat and had increased since winter in this habitat particularly. Spring numbers had also increased in upland as opposed to bottomland forest, with the change especially notable in the south, where densities in bottomland forest in spring were lower than winter levels. In the central region, where all forest is at a premium, spring densities increased in both upland and bottomland but more in upland (Table 1 and 2). We saw more jays on the western than on the eastern side of the state in both southern and central Illinois, with highest numbers in the IIlinois valley.

Flight directions of jays in spring tend to be to the northeast, and jays banded north of Illinois and later recovered in Illinois have come mainly from Michigan (Fig. 4). Marked exceptions to this trend are indicated by band recoveries in Iowa (Stoner 1929) and in South Dakota (Holcombe and Yeomans 1939).

\section{Distribution}

A species of eastern and central North America (Fig. 6), the blue jay is believed to be increasing in the western part of its range (Bock and Lepthien 1976). Because urban residential areas are an important habitat for the jay, it almost certainly nests in every township in Illinois, notwithstanding Figure 2, where we have plotted all records known to us.

\section{Nesting Habitats and Populations}

Kendeigh's (1982) study in Trelease Woods suggests important characteristics of the forest habitat preferred by jays. For many years jay numbers remained low at this site until the forest canopy was disrupted by tree deaths from elm disease. With that change, jays increased markedly and did not decline again when new tree growth closed the canopy. This apparent adaptability to variation in tree spacing may make it difficult to define the habitat. Towns, which 


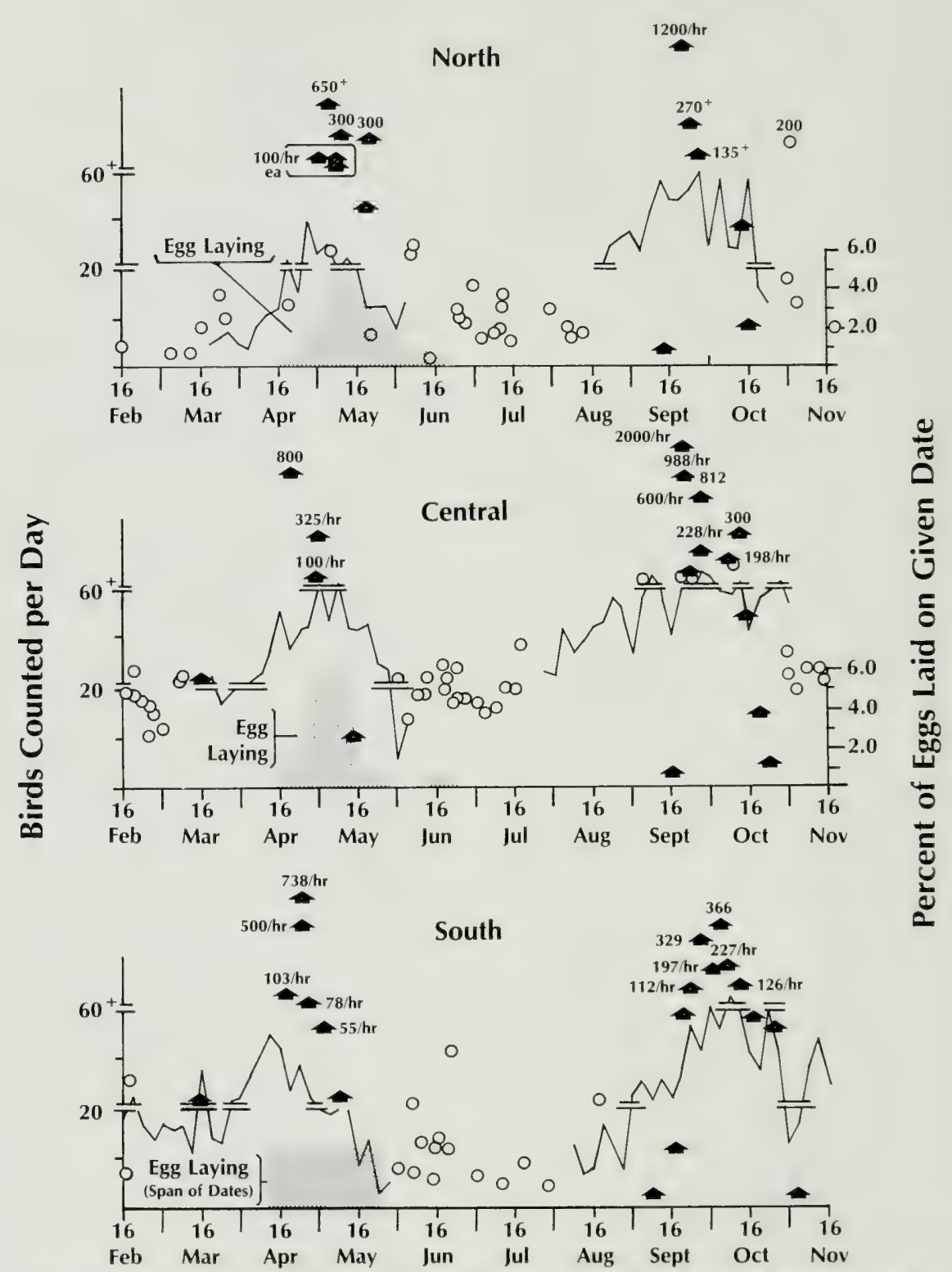

Fig. 5.-Egg-laying and migration seasons of the blue jay in north, central, and south regions of lllinois (see Fig. 3 for region boundaries). Spring and fall lines show the highest daily count of each 4 days (1967-1970). Circles represent counts made in other years or by other observers. Shaded areas show the percentage of eggs laid on each date (north and central) and the span of dates during which egg laying has been recorded (south). Arrows represent counts of diurnal migrations. 
have long been known as good habitat for jays (Allen 1868; Ridgway 1878; Nehrling 1883; Hess 1910), also characteristically have open spacing of trees and shrubs. Formerly, orchards had high densities of jays (Hess 1910), but modern orchards apparently do not (Table 3), though more data are needed to verify this observation. Forest-edge and shrub habitat also has open space and high numbers of jays, and edge shrub has particularly high numbers (Table 3 ). The number of jays in the towns we censused was consistently higher than the number in mature natural forest (Table 3). Towns had lower densities of trees (37-59/ha) than mature forests $(268-480 /$ ha $)$, but we did not find a direct relationship between jay densities and tree densities. One can surmise that the attractiveness of towns relates especially to the presence of bird feeders, but comparative studies of jay populations in towns and in more natural forest and shrub habitat are desirable.

Tree species mentioned as associated with jay habitat were black oaks (Gates 1911), shingle, and blackjack oaks (Etter 1963), and oak and/or hickory in general (Cahn and Hyde 1929). None of our study areas (see J.W. Graber et al. 1977, 1983) contained noteworthy numbers of shingle or blackjack oaks, but shingle oak was prominent in forest edge and shrub, a high-density jay habitat. Neither oaks in general nor hickories in general showed a quantitative relationship to jay numbers in our study areas. The blue jay's range is roughly similar to that of the black oak group Erythrobalanus (Fowells 1965). In our study areas of bottomland forest in southern Illinois, pin oak (Quercus palustris) densities and jay densities correlated $(r=0.6124, n=10)$, with a higher correlation for pin oak and cherrybark oak ( $Q$. falcata pagodaefolia) combined $(r=0.798, n=10, p=<0.01,>0.001)$. Pin oaks are generally absent from upland forest. In upland forest, black oak ( $Q$. velutina) tended to be correlated with jay numbers $(r=0.783, n=6, p=<0.05$, $>0.02$ ), excluding data from one upland tract (Possum Trot) in northern Alexander County where a high density of black oak $(50 / \mathrm{ha})$ was associated with moderate numbers of jays (3/40 ha). Gates (1911) noted that the jay was a dominant species in both mesophytic and drier forest along the Illinois River where black oak was a dominant tree.

After an area in southern Illinois had been stripmined, jays occupied the habitat as early as $6-9$ years after stripping (Brewer 1958), and in central Illinois Kendeigh (1982) found that jays reached their maximum population level 40 years after cultivation ceased on farm land.

The list of plants used as nest sites by blue jays (Table 4), reflects their principal habitats - urban residential (cultivated conifers and spiny rosaceous shrubs), edge (osage orange), and the oaks and maples of the forest and forest edge. These plants comprised about 60 percent of the nest trees. Hickories (Carya), notwithstanding their availability in nature, were seldom used as nest trees (Table 4).

Heights of 226 Illinois nests of the blue jay ranged from 3 to $80 \mathrm{ft}(0.9$ to $24.4 \mathrm{~m})$ with modes of $5-12$ $\mathrm{ft}(1.5-3.7 \mathrm{~m}), 15-20 \mathrm{ft}(4.6-6.1 \mathrm{~m})$, and $30 \mathrm{ft}(9.1$ $\mathrm{m})$. The average height was $12.4 \mathrm{ft}(3.8 \mathrm{~m})$.

The population of blue jays declined greatly (50$80 \%$ ) between 1907 and 1957 throughout Illinois and in virtually all but urban residential habitats (R.R. Graber and J.W. Graber 1963, Table 3). Barnes (1890)

TABLE 1. - Spring and fall population densities of the blue jay in Illinois (1979-1981).

\begin{tabular}{|c|c|c|c|c|c|}
\hline \multirow[b]{2}{*}{ Season and Habitat } & \multirow{2}{*}{$\begin{array}{l}\text { County } \\
\text { or } \\
\text { Region }\end{array}$} & \multirow{2}{*}{$\begin{array}{c}\text { Number } \\
\text { of } \\
\text { Censuses }\end{array}$} & \multirow{2}{*}{$\begin{array}{c}\text { Cumulative } \\
\text { Hectares } \\
\text { Censused }\end{array}$} & \multicolumn{2}{|c|}{ Birds per 40.5 ha } \\
\hline & & & & Maximum & Mean \\
\hline \multicolumn{6}{|l|}{ Spring (23 May-31 May) } \\
\hline Mature bottomland forest & Piatt (C) & 12 & 241 & 33.3 & 15.1 \\
\hline Mature bottomland forest & Johnson (S) & 21 & 436 & 35.1 & 8.3 \\
\hline Mature upland forest & Piatt (C) & 15 & 316 & 54.0 & 19.1 \\
\hline Mature upland forest & Pope (S) & 22 & 454 & 35.9 & 14.8 \\
\hline Forest edge and shrub & Piatt (C) & 13 & 261 & 61.4 & 30.8 \\
\hline Forest edge and shrub & Pope (S) & 20 & 394 & 63.8 & 19.2 \\
\hline Loblolly pines & Pope (S) & 12 & 214 & 18.0 & 5.3 \\
\hline \multicolumn{6}{|l|}{ Fall (1 August-3 November) } \\
\hline Mature bottomland forest & $\operatorname{Piatt}(\mathrm{C})$ & 27 & 541 & 52.3 & 19.2 \\
\hline Mature bottomland forest & Johnson (S) & 23 & 483 & 85.5 & 15.9 \\
\hline Mature upland forest & Piatt (C) & 31 & 601 & 91.2 & 21.4 \\
\hline Mature upland forest & Pope (S) & 22 & 452 & 44.9 & 17.5 \\
\hline Forest edge and shrub & Piatt (C) & 29 & 586 & 142.5 & 64.2 \\
\hline Forest edge and shrub & Pope (S) & 24 & 484 & 113.3 & 38.2 \\
\hline Loblolly pines ( $1979-1980$ only) & Pope (S) & 13 & 228 & 25.0 & 8.9 \\
\hline
\end{tabular}


TABLE 2.-Winter populations of blue jays in various Illinois habitats.

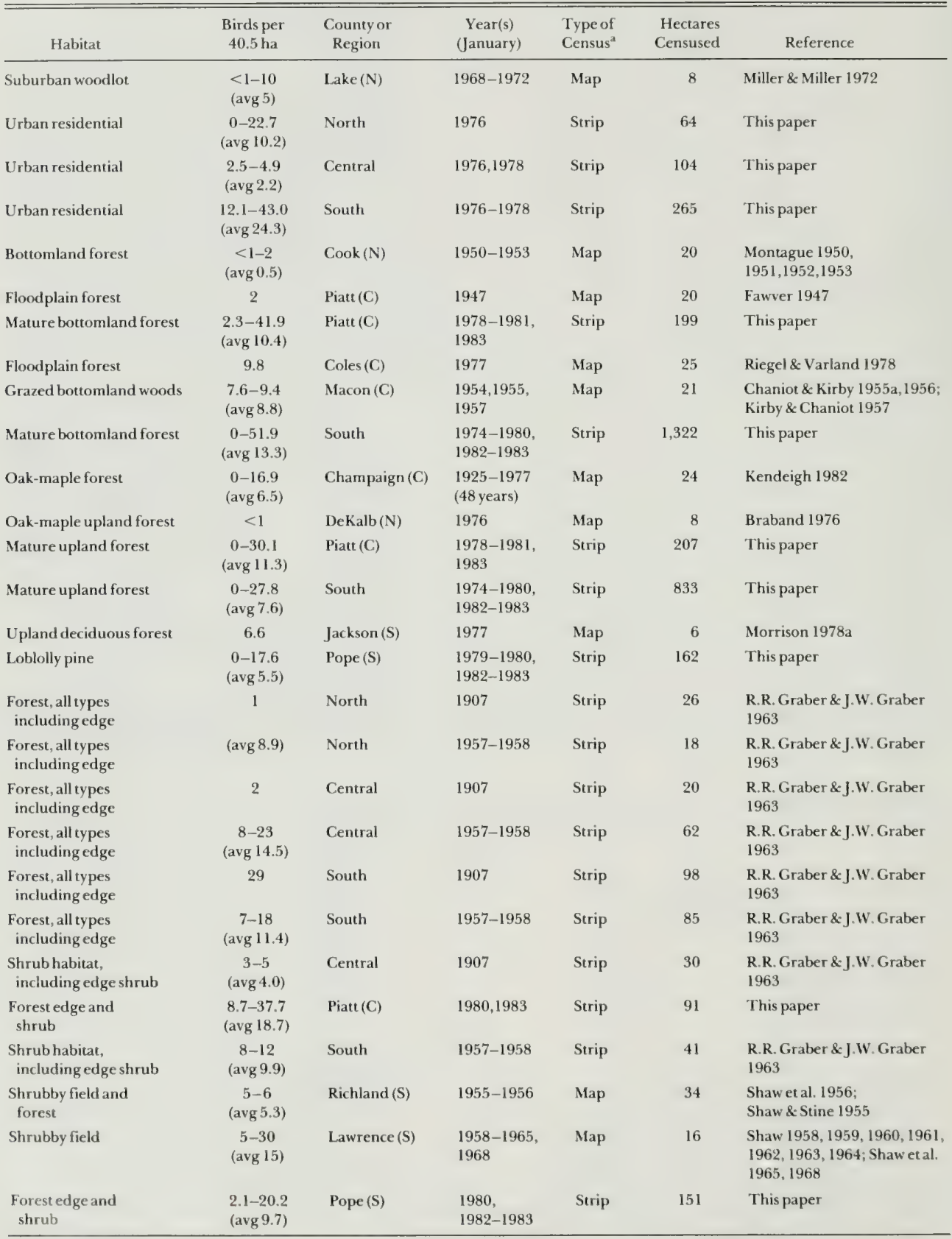


TABLE 2.-continued.

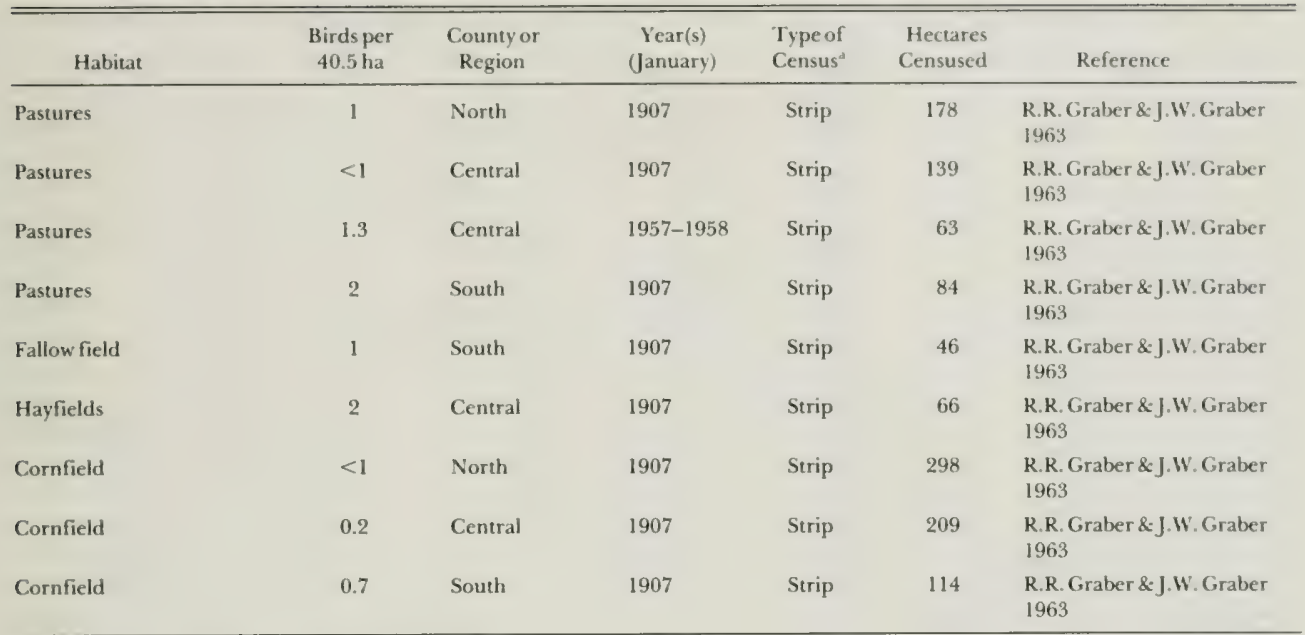

¿Strip censuses calculated as cumulative hectares.

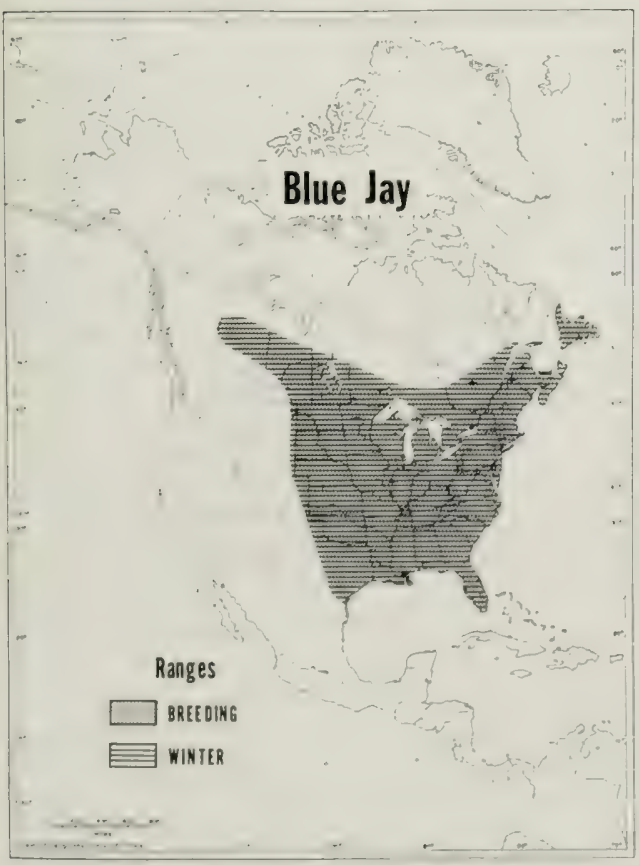

Fig. 6.-General distribution of the blue jay. believed the decline began even earlier. The reduction in numbers was particularly severe in the south $(81 \%)$. We conjecture that the loss may have followed the change of edge habitats to block habitats, especially after 1920

Territorial behavior in the blue jay is difficult 10 detect (Weise 1951; Calef 1953a; M.J. Robertson 1959), although Calef observed defense of a small area around the nest early in the nesting cycle (during building and early incubation).

\section{Nesting Cycle}

Numerous recoveries of banded birds document the return (or abidance) of jays-adults at least-to their general nesting area (Lyon 1924; Lincoln 1927; Flentge 1938; M.T. Cooke 1942; Jurica 1961; Jurica et al. 1962; Bartel 1962; Bartel et al. 1963; and others). Many of the jays banded were transients whose breeding places were unknown. Of 594 jays banded by Bartel (1966) in 32 years, 34 returned to the place of banding, and these were not necessarily all local nesters. There appear to be many patterns of migration behavior. Lyon (1934) mentioned a banded jay that returned to his place 4 years in spring and 2 other years in fall in a period of about 11 years.

As it appears that some jays migrate and others do not and that, furthermore, as there is annual variation in the behavior, the onset of nesting could be expected to be highly variable. 
TABLE 3.-Breeding populations of blue jays in various Illinois habitats.

\begin{tabular}{|c|c|c|c|c|c|c|}
\hline Habitat & $\begin{array}{c}\text { Birds per } \\
40.5 \text { ha }\end{array}$ & $\begin{array}{l}\text { County or } \\
\text { Region }\end{array}$ & Year(s) & $\begin{array}{l}\text { Type of } \\
\text { Census }^{a}\end{array}$ & $\begin{array}{r}\text { Hectares } \\
\text { Censused }\end{array}$ & Reference \\
\hline Urban residential & 16 & North & 1958 & Strip & 65 & $\begin{array}{l}\text { R.R. Graber \& J.W. Graber } \\
1963\end{array}$ \\
\hline Urban residential & 16 & Central & 1958 & Strip & 30 & $\begin{array}{l}\text { R.R. Graber \& J.W. Graber } \\
1963\end{array}$ \\
\hline Urban residential & 21 & South & 1958 & Strip & 40 & $\begin{array}{l}\text { R.R. Graber \& J.W. Graber } \\
1963\end{array}$ \\
\hline Urban residential & $\begin{array}{c}4-47 \\
\text { (avg 17.2) }\end{array}$ & South & $1976-1977$ & Strip & 139 & This paper \\
\hline Urban cemeteries & $\begin{array}{c}0-2 \\
\text { (avg } 1.1)\end{array}$ & $\operatorname{Cook}(\mathrm{N})$ & 1974 & Nest & 414 & Lussenhop 1977 \\
\hline $\begin{array}{l}\text { Modified woodland } \\
\text { (human housing) }\end{array}$ & 22 & Lake $(\mathrm{N})$ & 1937 & Nest & 11 & Beecher 1942 \\
\hline Unmodified woodland & 15 & Lake (N) & 1937 & Nest & 11 & Beecher 1942 \\
\hline $\begin{array}{l}\text { Suburban estate } \\
\text { (parkland) }\end{array}$ & 7 & $\operatorname{Cook}(\mathrm{N})$ & 1915 & & 32 & Eifrig 1915 \\
\hline $\begin{array}{l}\text { Forest, all types } \\
\text { including edge }\end{array}$ & $\begin{array}{c}5-7 \\
(\operatorname{avg} 6.2)\end{array}$ & North & $1957-1958$ & Strip & 72 & $\begin{array}{l}\text { R.R. Graber \& J.W. Graber } \\
1963\end{array}$ \\
\hline Forest, all types & $\begin{array}{c}8-17 \\
(\operatorname{avg} 13.1)\end{array}$ & Central & $1957-1958$ & Strip & 87 & $\begin{array}{l}\text { R.R. Graber \& J.W. Graber } \\
1963\end{array}$ \\
\hline Forest, all types & 35 & South & 1907,1909 & Strip & 24 & $\begin{array}{l}\text { R.R. Graber \& J.W. Graber } \\
1963\end{array}$ \\
\hline Forest, all types & $\begin{array}{c}2-3 \\
(\operatorname{avg} 2.6)\end{array}$ & South & $1957-1958$ & Strip & 138 & $\begin{array}{l}\text { R.R. Graber \& J.W. Graber } \\
1963\end{array}$ \\
\hline $\begin{array}{l}\text { Virgin floodplain } \\
\text { forest }\end{array}$ & 6 & Sangamon $(\mathrm{C})$ & 1948 & Map & 31 & Snyder etal. 1948 \\
\hline Floodplain forest & $\begin{array}{c}8-32 \\
(\text { avg } 16.0)\end{array}$ & Piatt (C) & $\begin{array}{l}1949-1951 \\
1963,1967\end{array}$ & Map & 10 & Kendeigh 1982 \\
\hline $\begin{array}{l}\text { Mature bottomland } \\
\text { forest }\end{array}$ & 8 & McLean (C) & $1950-1951$ & Map & 25 & Calef 1953a,b \\
\hline $\begin{array}{l}\text { Mature bottomland } \\
\text { forest }\end{array}$ & $\begin{array}{c}7-35 \\
(\operatorname{avg~15.5)}\end{array}$ & Central & $1978-1981$ & Strip & 193 & This paper \\
\hline Bottomland forest & 26 & Vermilion $(\mathrm{C})$ & 1966 & Map & 6 & Karr 1968 \\
\hline Bottomland forest & 22 & $\begin{array}{l}\text { Willow Slough, } \\
\text { Indiana }\end{array}$ & 1974,1978 & Map & 11 & Hopkins 1974,1978 \\
\hline $\begin{array}{l}\text { Grazed stream } \\
\text { bottomland forest }\end{array}$ & 8 & $\operatorname{Macon}(\mathrm{C})$ & 1955 & Map & 21 & Chaniot \& Kirby 1955b \\
\hline $\begin{array}{l}\text { Mature bottomland } \\
\text { forest }\end{array}$ & $\begin{array}{c}0-22 \\
(\text { avg } 3.9)\end{array}$ & South & $1973-1981$ & Strip & 1,129 & This paper \\
\hline $\begin{array}{l}\text { Riparian oak-hickory } \\
\text { forest }\end{array}$ & 10 & Wayne (S) & 1980 & Map & 8 & Keener 1981 \\
\hline Woods (unspecified) & $\begin{array}{c}7-11 \\
(\operatorname{avg} 7.8)\end{array}$ & Rock Island (N) & $1917-1923$ & & 22 & J. J. Schafer unpublished \\
\hline Oak-maple forest & $\begin{array}{c}0-7 \\
(\operatorname{avg~1.2)})\end{array}$ & Champaign (C) & $1927-1952$ & Map & 24 & Kendeigh 1982 \\
\hline Oak-maple forest & $\begin{array}{c}7-64 \\
(\operatorname{avg} 33.7)\end{array}$ & Champaign (C) & $1953-1976$ & Map & 24 & Kendeigh 1982 \\
\hline Upland forest & $\begin{array}{c}3-19 \\
(\text { avg } 11.3)\end{array}$ & Piatt (C) & $\begin{array}{l}1949-1951 \\
1962,1964 \\
1966\end{array}$ & Map & 13 & Kendeigh 1982 \\
\hline $\begin{array}{l}\text { Upland oak-hickory } \\
\text { forest }\end{array}$ & 30 & Hancock (C) & 1967 & Map & 10 & Franks \& Martin 1967 \\
\hline $\begin{array}{l}\text { Oak-hickory-maple } \\
\text { forest }\end{array}$ & $\begin{array}{c}<1-12 \\
(\operatorname{avg} 7.6)\end{array}$ & McLean (C) & $1977-1981$ & Map & 13 & $\begin{array}{l}\text { Birkenholz } 1977,1978,1979, \\
1980,1981\end{array}$ \\
\hline
\end{tabular}


TABLE 3.-continued.

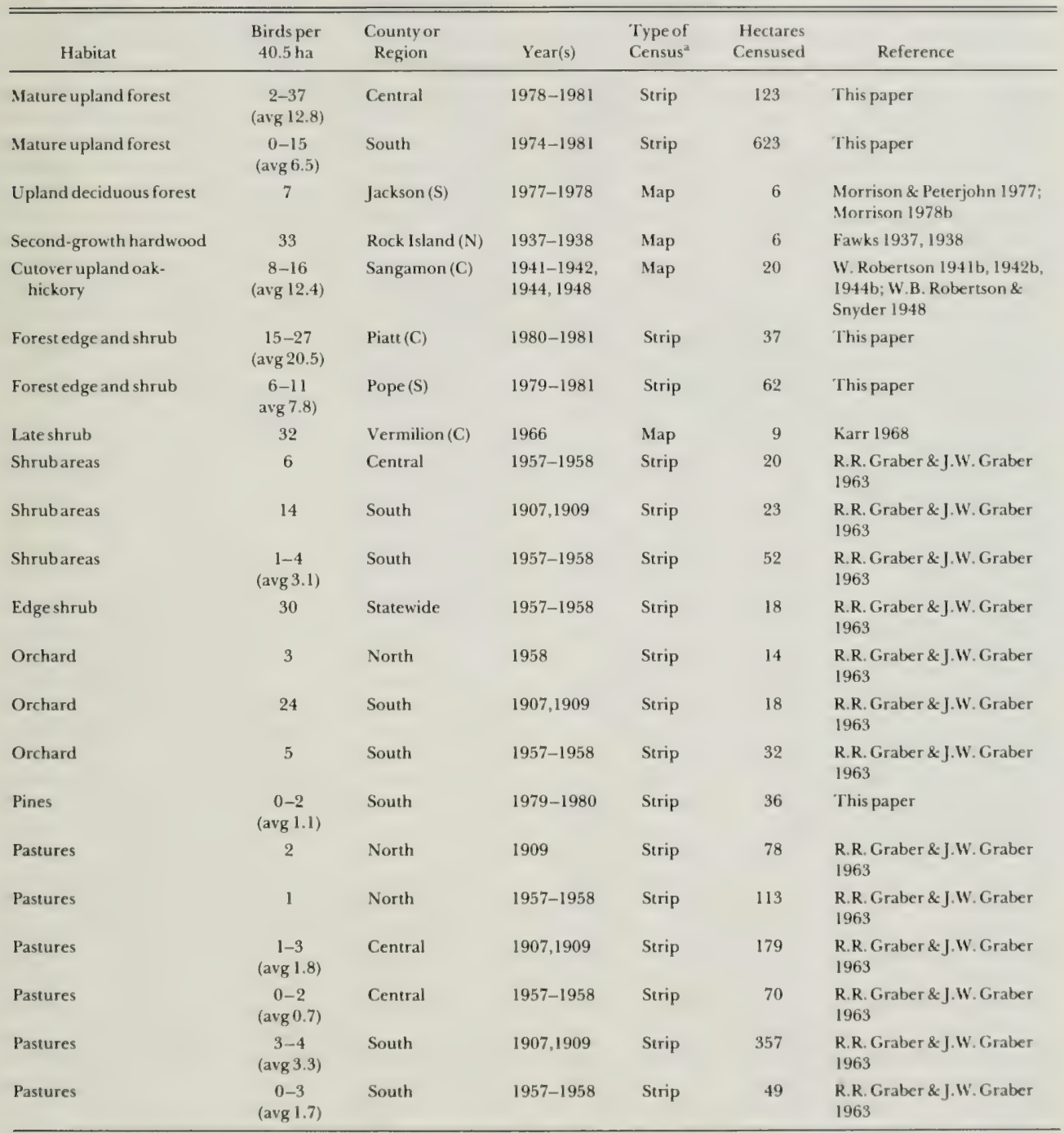

${ }^{2}$ Strip censuses calculated as cumulative hectares.

What may be courtship feeding-one jay to another (Wheat 1886) - has been observed in midwinter as well as in spring (Roberts 1918). The blue jay's courtship behavior, as described by Hardy (1961) in eastern Kansas, is rather prolonged and complicated and involves several types of calls. A flock consisting of males and apparently one female ranges over an area about one-fourth mile in diameter, chasing each other, performing bobbing (bowing) and flight displays, and sometimes fighting. The number of males in the flock decreases until only the male that mates with the female remains. Comfort (1955) described such behavior in spring, noting that the birds uttered a bell-toned call as they bobbed; how- 
ever, he also associated such behavior with winter. Hardy (1961) believed that such performances by yearling birds were abbreviated or lacking and that some first-year birds do not breed. A pretty song described by Dickinson (1884) probably relates to courtship but is not commonly heard. The "jay" or "jayer" calls may have several functions, depending on delivery, and are heard during migration, during courtship (Hardy 1961), and as an alarm call (?) at any season. Musselman (1936) referred to the "barndoor" call ("squeaky gate" ?) in late winter at Quincy,

TABLE 4.-Plants recorded as nest sites of blue jays in (mainly northern and central) Illinois. Scientific names are included only when provided in the original source.

\begin{tabular}{|c|c|c|}
\hline Plants & Number & Percent \\
\hline Hawthorn (Crataegus sp.?), thorn apple & 29 & 11.6 \\
\hline Osage orange (Maclura pomifera) & 24 & 9.6 \\
\hline Crab apple (Malussp.?), crab & 18 & - \\
\hline $\begin{array}{l}\text { Domestic apple + percent for all } \\
\text { Malus combined }\end{array}$ & 9 & 10.8 \\
\hline White oak (Quercus alba) & 18 & - \\
\hline Black oak (Q.velutina) & 4 & - \\
\hline Red oak & 3 & - \\
\hline Blackjack oak (Q. marilandica) & 2 & - \\
\hline Chestnut oak & 1 & - \\
\hline Shingle oak & 1 & - \\
\hline "Oak" + percent for all oaks combined & 17 & 18.4 \\
\hline Sugar maple, hard maple, maple & 13 & - \\
\hline Silver maple, soft maple & 3 & - \\
\hline $\begin{array}{l}\text { Box elder (Acer negundo) }+ \text { percent for } \\
\text { all maples combined }\end{array}$ & 7 & 9.2 \\
\hline Red cedar (Juniperus virginiana), cedar & 12 & 4.8 \\
\hline Pine, Austrian, white, loblolly & 12 & 4.8 \\
\hline Spruce, Norway, blue & 11 & 4.4 \\
\hline Hemlock & 1 & - \\
\hline "Evergreen" & 3 & - \\
\hline Elm, slippery elm & 11 & 4.4 \\
\hline $\begin{array}{l}\text { Black willow (Salix nigra), willow, } \\
\text { weeping willow }\end{array}$ & 9 & 3.6 \\
\hline $\begin{array}{l}\text { Wild cherry (Prunus serotina), } \\
\text { choke cherry }\end{array}$ & 6 & 2.4 \\
\hline Grape & 5 & 2.0 \\
\hline Green ash (Fraxinus pennsylvanica), Ash & 4 & 1.6 \\
\hline Honey locust (Gleditsia triacanthos) & 4 & 1.6 \\
\hline Black locust & 1 & - \\
\hline Hackberry & 4 & 1.6 \\
\hline Poplar, cottonwood & 3 & 1.2 \\
\hline River birch & 3 & 1.2 \\
\hline Honeysuckle, Japanese honeysuckle & 3 & 1.2 \\
\hline Mulberry & 2 & 0.8 \\
\hline Sweet gum & 2 & 0.8 \\
\hline American holly & 1 & 0.4 \\
\hline Hickory & 1 & 0.4 \\
\hline Lilac & 1 & 0.4 \\
\hline Sycamore & 1 & 0.4 \\
\hline Total & 250 & 99.6 \\
\hline
\end{tabular}

a call associated with courtship flocks (Hardy 1961). The function of the hawklike calls, imitative especially of the red-shouldered hawk (Buteo lineatus) (Prager 1976; Swink 1976) and the immature red-tail ( $B$. jamaicensis), is apparently unknown. When jays are harassing a sharp-shinned hawk (Accipiter striatus), or vice versa, they utter a harsh call ("skowarp"), especially when the hawk makes a pass at them. The blue jay's vocabulary is large, and Illinois students have barely touched the subject.

The late stages of courtship may include the building of a "false" nest, an accumulation of twigs that lacks the form of a true nest (Hardy 1961). This activity precedes or overlaps the building of the true nest. Nest building (true nests?) has been recorded as early as 2 March (W.W. Cooke 1885) and 17 March in central Illinois (Du Mont and Smith 1946) and as "late March" in the north (Gault 1901) through April, with later nestings common in May and extending at least to mid-July. Both mates help with nest building (Silloway 1906a), and the structure is composed mainly of small twigs, grass, and weed stems; it is lined with rootlets and often includes pieces of paper, cloth, and string (Silloway 1906a; Bent 1946). Nest construction in southern and central Illinois has taken as long as 26 days (to first egg), but more typically requires 8 or 9 days. Lining one nest took 3 days. Typically, the site is an exposed, stout crotch in a group of young trees near the edge of a woods. Occasionally the nest is built on or in a building (Ridgway 1874; Deane 1899; Silloway 1906a), and rarely the pair will usurp the nest of another species (e.g., a robin, W.E. Loucks, unpublished 1899). Goelitz (1916) reported the reuse of one nest in Urbana, a rare occurrence in any passerine species.

Egg laying has been recorded at least as early as 12 April in southern Illinois and 16-17 April in the central and northern regions (Fig. 5). The laying curve shows the peak of egg production from late April to mid-May and seems to imply that one brood is the rule; however, the data probably slight late season nests and renestings after nest failures. Information on the number of broods depends on studies of banded populations (see Hickey 1952). Gault's observation (unpublished 1916) of jays in copulation on 21 July at Glen Ellyn suggests egg laying later than the dates shown in Figure 5.

The eggs are highly variable in color, ranging in background color from buff to blue and speckled and blotched with shades of brown or olive. Data from 141 nests in Illinois (statewide) showed clutch distribution as follows: six eggs: 6 (4\%), five eggs: $89(63 \%)$, four eggs: 40 (28\%), three eggs: $4(3 \%)$, two eggs: 2 (1\%). The sample included nests with eggs only and excluded clutches stated to be selected for large num- 
bers of eggs. Many of the data were based on one-time observations (e.g., museum specimens) and may be low either because the clutch had not been completed at the time of the visit or because one or more eggs had been lost before the visit. No regional differences in clutch size were apparent in the sample, though more nests from southern Illinois are needed to test this statement statistically. Clutch size declined with the passing season (April/May average: $4.70 \mathrm{eggs}$, June average: 4.27 ) as is the case for other species of birds. The sample of nests represented years from 1882 to 1980. The average clutch size in April and May before 1940 was 4.72 eggs $(n=61)$; after 1940 it was 4.68 eggs $(n=78)$, remarkably constant. Bodensten (1932a) reported a jay nest that had 7 eggs, an unusually large set.

Incubation is by the female only, as is general among corvids (Hardy 1961). The male brings food to the incubating female. At one central Illinois nest, the incubation period from laying to hatching of the last (fourth) egg was 17.5 days (K. Spitze, unpublished 1980). Nestling life at five nests (one in southern, three in central, and one in northern Illinois) lasted 20, 17, 18,16 , and 16 days, respectively. Both parents feed the young. The time required for a successful nesting, from building through fledging for a nest that received five eggs would thus be about 48 days, 10-15 days longer than for many songbirds.

Success in a sample of 29 nests about equally divided among the three regions of the state was 66 percent for nests and 52 percent for eggs, both higher rates than we have seen generally for songbirds in Illinois. Successful nests produced an average of 3.5 fledglings, a high production compared with most 11linois songbirds. There is but one record of cowbird parasitism (Blocher 1933; Friedmann 1963).

Causes of nest failure are poorly known, but in the sample of 29 nests cited above, 2 were known to have been destroyed by mammals (at least 1 by a fox squirrel, Sciurus niger). Nests observed by Gault (unpublished 1915) and Finley (1917) were also destroyed by mammals (cat, fox squirrel). Gault (unpublished 1894) also reported cat predation on a juvenile jay. Little is known about postfledging mortality.

\section{Fall}

In August and September the jay's molt becomes obvious as blue feathers appear everywhere on the forest floor and the birds, some with bald heads, become wretched looking. In early August many young jays are still partly in juvenile plumage. Precisely how the molt fits into the pattern of other fall activities needs to be determined.

Two activities that begin in August-mast gathering and migration-increase greatly in September and
October. How these and the storing of mast fit into sequence need study.

The fall migration may differ from the spring flights in being even more concentrated along the major rivers, though we also see smaller cross-country flights in fall. The patterns are otherwise as in spring (see above, also Widmann 1907). The birds pass over or near the scarp of a floodplain, usually coming in "pulses" 5 to $10 \mathrm{~min}$ apart, sometimes singly but more often in strings of 5 to more than 100 birds. Migrating jays may pause more often in fall than in spring (further data are needed). Not infrequently, one (a local bird?) will be seen carrying an acorn. Mast gathering intensifies in late September and October. (Do transients engage in this activity before reaching winter quarters?) The diurnal timing of the flights is also similar to the timing in spring-approximately $1 \mathrm{hr}$ after sunrise to 1000-1200 CST and again after 1500 CST. The flight often tapers off after 1000 and is generally small in the afternoon and evening relative to the morning. Widmann (1907) noted that flights at St. Louis came from the fourth week of September to mid-October. These dates roughly bracket the larger migrations on the major rivers, including the Ohio, where we have observed small migration flights of jays as early as 9 September and as late as 4 November (Fig. 5). The earliest and latest flights are probably overlooked because of their low volume. Our earliest fall records of flights for northern and central Illinois were 13 and 16 September, respectively, and our latest, 16 and 24 October-all lowvolume flights (25 birds or fewer per hour passing the observation point). Both earlier and later records are to be expected. A flight on the Sangamon River, 12 October, was $180 / \mathrm{hr}$.

The geography of the blue jay migration, along with the rest of its natural history, needs study. Our occasional checks of smaller rivers-the Wabash, Kaskaskia, and Embarras-have revealed very low flight volumes, but the largest flight observed at Forest Glen (Vermilion River) was a respectable $230 / \mathrm{hr}$ on $28 \mathrm{Sep}$ tember (M. Campbell, unpublished 1975). All rivers and prominent topographic features need to be checked for jay migration before we can understand the event. Our impression is that even the Ohio Kiver (peak count: $400 / \mathrm{hr}$ in fall) does not carry nearly the volume of jay migration that the Illinois $(2,000 / \mathrm{hr}$ at least once, Bohlen 1978) and the Mississippi $(1,000+/ \mathrm{hr}$, often from late September to midOctober) do. The Sangamon River (peak: 600/hr) appears to have a higher rate than most, but many Illinois rivers have not been checked. Observations are also lacking for the lower Illinois River. We have observed a high volume of jay migration on the Mississippi south to about St. Louis, but in a few attempts have failed 
to see migration further south on the river, an observation that leads us to believe that the jays turn westward into Missouri. More observations are needed on both sides of the river. Jays also appear to leave the Ohio River near Golconda and turn westward to the scarp of the old Ohio floodplain that transects the southern tip of Illinois, a pattern that suggests a long history of jay migration in this area. Many jays may quit the migration in southern Illinois and Missouri, but many (most?) are going further south (Fig. 4). Regular counts through the migration seasons over a period of years are needed for data on annual variation. We suspect that fall flights are initiated by the arrival of cold fronts and continue both behind and ahead of fronts as jays catch and pass slow-moving air masses.

We have seen a number of other species flying the routes that jays use, and at the same times. The redheaded woodpecker (Melanerpes erythrocephalus) is most prevalent. Others are red-bellied woodpecker (M. carolinus); yellow-shafted flicker (Colaptes auratus); yellow-bellied sapsucker (Sphyrapicus varius); downy woodpecker (Picoides pubescens), least frequently seen of the woodpeckers in the migration and probably adventitious; belted kingfisher (Ceryle alcyon); chimney swift (Chaetura pelagica), this species and the swallows (rough-winged, Stelgidopteryx, and tree, Tachycineta) may occur only accidentally on the migration routes of blue jays since most of the migration of these three species takes place elsewhere; American crow (Corvus brachyrhynchos); black-capped chickadee (Parus atricapillus), seen but once; tufted titmouse ( $P$. bicolor), seen but once; red-breasted nuthatch (Sitta canadensis), usually a night migrant and probably adventitious with the jays; eastern bluebird (Sialia sialis); American robin (Turdus migratorius); cedar waxwing (Bombycilla cedrorum); European starling (Sturnus vulgaris); myrtle warbler (Dendroica coronata), this and the next three species usually as night migrants; bay-breasted warbler (D. castanea); rose-breasted grosbeak (Pheucticus ludovicianus); indigo bunting (Passerina cyanea); redwinged blackbird (Agelaius phoeniceus); meadowlark (Sturnella species?); common grackle (Quiscalus quiscula); brown-headed cowbird (Molothrus ater); purple finch (Carpodacus purpureus); and American goldfinch (Carduelis tristis). This list is probably not a complete one of birds that may be found migrating with blue jays. Hawks that we have identified with the blue jay migration are the osprey (Pandion haliaetus) and broadwinged hawk (Buteo platypterus), probably accidental associations, and sharp-shinned hawk, seen many times, often apparently playing with a flock of jays or flickers and vice versa. Monarch butterflies (Danaus plexippus) are also frequently associated with the jay migrations in fall.
Most birds rely on other migration routes and methods more than on the routes and methods of jays. A few birds may simply become entrained. This behavior is not true of the red-headed woodpecker, of course, which moves thousands of birds on "jay" routes. Bluebirds and robins migrate in much the same way as jays but often on different routes and at different times. This pattern is true also of swifts and swallows, crows, starlings, blackbirds, and finches. We may never understand this phenomenon, but more quantitative data might help.

A migrating jay is commonly seen to pause, pick up an acorn, and carry it about. This activity may be strictly foraging, the source of calories that support the migration, but it may also be the beginning of gathering and storing behavior, a primary occupation especially in October, presumably for birds that have reached their winter quarters. This intensive activity is similar to that of the red-headed woodpecker (R.R. Graber and J.W. Graber 1979). Precisely when it begins we do not know, but we have observed the picking of mast as early as 20 August in northern Illinois. We have not seen the storing of mast until about 20 September in central and extreme southern Illinois, where it is most intensive throughout October and then declines during November.

Shingle oaks (Quercus imbricaria) appear to be the first trees picked in central and southern Illinois. Several jays may work two or more weeks on a shingle oak before turning to an adjacent cherrybark oak. Each bird, after visiting three or four locations in the tree, carries one nut in its bill (plus others in its throat?) to various sites 50 to $500 \mathrm{~m}$ from the tree. The bird then places the nuts singly on the ground and covers them with leaves, puts them in crevices in trees, or deposits them in old bird nests. The process is peaceable and quiet for the most part and lasts most of the day, even in light rain, with a break at midday (11001400 CST).

Jays must play a role in seed dispersal, especially of some of the small-fruited oaks. In contrast to redheaded woodpeckers that store acorns in forest trees, the jay's storage is at the edge or in the open, though not far from some woody habitat. What part of the cache is later retrieved is apparently unknown. Certainly unstored foods are also used in winter. Other mast items that we have seen jays pick in fall are hazelnuts (Corylus americana), which were not stored, and pecans (Carya illinoensis).

The ratio of our spring counts to our fall counts was 1.0 to 1.9 jays, with almost no variation from region to region. These figures excluded actively $\mathrm{mi}-$ grating birds. The ratios of spring birds to fall birds in our census transects were 1.0 to 1.6 in east-central 
Illinois and 1.0 to 1.7 in the south. All ratios indicate some productivity; however, daily counts of migrating flights, spring and fall, might produce different ratios. Age ratios in a large sample of fall specimens might be the best indicator of production. Pitelka's (1946) idea that the proportion of young jays among migrants increases with latitude, especially north of $40^{\circ} \mathrm{N}$, has apparently not been tested.

Forest-edge and shrub habitat had the highest densities of jays in fall, as in spring; pines had the lowest (Table 1). Our censuses of woody habitats show that the population of independent (nonjuvenile) jays reaches its annual high in fall-about 2 or 3 times higher than in summer or winter and 1.6 times higher than in spring.

\section{Winter}

If the end of the fall flights are indicative, winter populations of jays are generally in place by early November. Additional support for this statement is found in the earliest recoveries of northern banded birds deep in the winter range: Brownsville, Texas, on 1 November (U.S. Biological Survey 1937-1938); West Monroe, Louisiana, on 12 December (Downing 1941); and Sulphur Rock, Arkansas, on 10 December (Lincoln 1939). Jays are present throughout Illinois in winter (Fig. 3) and, because they are attracted to human residential areas, are surely to be found in every township. In the north, however, the jay population reaches its lowest level of the year in JanuaryMarch (Dillon 1968). The statewide censuses indicated that about 80 percent of the state population was in the southern region in winter (R.R. Graber and J.W. Graber 1963). The gradient, an increase from north to south of jays in winter, was markedly steeper in 1900 than it is now (Table 2), a change that may reflect the recent increase in winter feeding of birds by humans. At Rockford, Van Duzer (1916) and Riis (1921) noted large variations in the numbers of jays from winter to winter, as was the case at Trelease Woods (Kendeigh 1982). Though many must emigrate, some stay even in the north (Labahn 1941), and some stay some winters and emigrate others. This behavior is indicated by the pattern of cold season returns of surviving banded jays at Zion (Lyon 1933), where, on average, jays were present about one winter in three. High winter populations of jays at Trelease Woods coincided with high acorn production in 5 of 7 years (Kendeigh 1982). The relationship of jay numbers to specific mast species needs study at various places in the state, north and south.

The breeding population of jays in Illinois, as noted earlier, has declined about $50-80$ percent from its 1900 level. The decline in winter numbers was less $(30-45 \%)$ and occurred particularly in southern Il- linois, where despite the general decline, jays increased in urban residential habitat (R.R. Graber and J.W. Graber 1963, Table 2). Habitat preferences in winter were similar to those of summer but bottomland forest and residential habitat were relatively more important in winter in the south. Among woody habitats, pine stands seem least important based on population level (Table 2), but their importance as roosting habitat needs investigation. During the winter, jay populations increase in residential habitat and tend to decrease as much as 60 percent in other woody habitats between December and February (J.W. Graber and R.R. Graber 1983). We speculate that this decline represents mortality plus change of habitat. The decline is large even in mild winters. The low density of jays we found in urban residential habitat in central Illinois compared with densities in the north and south (Table 2) is mystifying. The subject needs special study over a period of years.

Clemans (1974) found the range of temperatures that captive jays could survive (about $50 \%$ of the sample) to be $-30^{\circ} \mathrm{C}$ to $30^{\circ} \mathrm{C}$ in winter and $8^{\circ} \mathrm{C}$ to $40^{\circ} \mathrm{C}$ in summer. Winter birds had lower rates of metabolism than summer birds. Gross energy intake was inversely related to temperature regardless of photoperiod. Equations for calculating existence metabolism in the blue jay are presented by Clemans (1974) and Pinowski and Kendeigh (1977).

In the north, Stoddard (1920) found a jay in its roost $(15+\mathrm{ft}$ high against the trunk of a thick cedar) by 1600 CST on 18 January.

\section{Food}

Crops of 36 blue jays collected by Burtis Wilson in the Davenport, Iowa, area, presumably at different seasons, contained nuts, corn, seeds, green shoots, beetles, larvae, other insects, and gravel (Hodges 1954). Le Baron (1853-1854) stated that jays feed chiefly on grain and ripe fruit. Among the caterpillars eaten are tent caterpillars - jays tear apart the tents (Kennicott 1853-1854; Hess 1913), linden loopers and other naked larvae (Thomas 1882), canker worms (Forbes 1881), other lepidoptera larvae (Forbes 1878), and the eggs of the tussock moth (Hulsberg $1917-$ 1918). Jays also eat cicadas and grasshoppers and probably many other insects.

The jay's propensity to eat eggs and nestlings of other birds has been well documented and includes rose-breasted grosbeak eggs (Sanborn 1911), house sparrow nestlings and older birds (Chase 1899; E.E. 1885; Pratt 1907), and eggs and nestlings of mourning dove (W.W. Cooke 1916) and purple martin (R.R. Graber 1962). Comfort (1945) reported the attack by a jay on a mourning dove in its nest. Ridgway (1920) thought that jays destroyed 75 percent of the eggs 
and young of other birds in Olney. Hodges (1949) believed the jay had a pronounced effect on the numbers of house sparrows. What part of the jay's food comes from such predation remains to be determined.

Other foods listed for the jay were domestic and wild fruits of apple, grape, hawapple, crab apple, wild cherry (Prunus serotina), and sumac (Gault, unpublished 1890 and 1903; D. Jones 1934); corn and pecans (W.W. Cooke 1885); beechnuts and acorns (Forbes 1878; Hess 1913); blossoms of Staphylea trifolia (G. Sanderson, unpublished 1981); swollen buds of sugar maple; and carrion-gizzard shad (Southern 1966) and road-killed cottontail. An abundance of mast is required in winter (W.W. Cooke 1885, 1888; Kendeigh 1982). Shingle oak and cherrybark oak acorns are particularly favored, and we have also often seen jays eating the fruit of dwarf sumac (Rhus copallina) in fall and winter (J.W. Graber and Powers 1981).

Jays come readily to food and water provided by humans (Craigmile 1937). Guth (1979) reported that jays found bread and sliced apples in a forest area within 45 minutes; on a city street they found and removed food within 35 minutes in one instance and within 1 minute in another. Jays regularly visit feeders (Jackson 1905; Beall 1908; Ritter 1909; Roberts 1920; Schantz 1922; Walker 1924), where they have been seen to take corn, cracked butternuts and walnuts (Schafer 1917), suet (Brintnall 1918), sunflower seeds (Bellrose 1934-1935), and cheese (Cone 1956).

\section{Mobbing Behavior}

The strong drive for jays to mob predators, especially owls, has at least the following Illinois examples: jays at an open horned owl nest (Franks and Warnock 1969), at the nest cavity of a screech owl (Lyon 1922), and at a dead barred owl specimen that continued to attract jays after it had been concealed in a box (Hess 1917). Bartel (1958) experienced something perhaps similar when he was attacked by a jay while banding a young catbird.

\section{Mortality and Longevity}

From band recoveries, including Illinois data, Hickey (1952) calculated annual mortality rates for jays to be 34-38 percent for first-year birds (he warned that the figures for this age group are probably unreliable) and 45 percent for adults. Downing (1949) had retrieval data on 81 banded blue jays ( 57 that returned to the banding site). Of these, ten were dead before 1 year of age, four by 2 years, five by 3 , one by 4 , one by 5 , one by 6 , one by 7 , and the oldest by 9 years. Bartel (1977) found the age of jays banded in winter that returned ( 3 of 83 ) to be 3,4 , and 7 years. Over a period of 42 years, Bartel banded 838 jays and recovered birds as old as 4 years, 4 months; 5 years, 6 months; and 6 years, 2 months (Bartel 1967, 1976). Yeomans (1950) reported a jay over 8 years old, and Lyon (1934) reported one at least 10 years old. M.T. Cooke $(1937,1950)$ and Higgins (1946) recorded five additional Illinois jays that were $6-8$ years. Jays that reach adulthood appear to be relatively longlived. The known life-spans (in months) of nine immature jays banded or recovered in Illinois were 6,9 , $11,27,30,34,34,37$; one bird was still alive at 37 months. For six of these birds, death came in fall or winter. For three, the causes of death were listed as caught by cat, killed by car, and shot by hunter(?) (Periodic Report by Region of Banding-234; Stocking 1974). Hickey (1952) listed the causes of death for 152 banded jays: cats, 70 ; automobiles, 31 ; storms, 18; striking wires, 16 ; drowning, 8 ; raptors, 5 ; dogs, 4. Additional Illinois references on mortality refer to winter (Roseberry 1962; J.W. Graber and R.R. Graber 1979) and storm kills (Bodensten 1934; Segal 1960), pesticides (Montgomery 1956), rat traps (Roberts 1919), automobiles (Flint 1934-1935), and predation by screech owls (Strode 1894; Brown and Bellrose 1943). The screech owl (Otus asio) appears to be a formidable predator on jays. Brown and Bellrose (1943) found the blue jay to be the most common item of prey in owl boxes, with a frequency of 20.5 percent in 259 samples. Indians apparently killed jays, possibly for their feathers (Parmalee 1962; Brown 1975).

Illinois jays have been found infected with blood parasites: two of five examined with Plasmodium circumflexum (McClellan 1948) and three of five with Haemoproteus(2), Leucocytozoon (1), and Trypanosoma (1) (Sachs 1948). Whether or not these parasites incapacitate the birds is not known.

\section{Specimen Data}

Ridgway (1904) noted a north-south size cline in Cyanocitta cristata cristata but concluded that southern Illinois breeding birds, though intermediate in size, were of that race, as did Oberholser (1921) and Brodkorb (1930; see also Ridgway 1925 and Mengel 1965). A larger, less purplish form (C. c. bromia) breeds in northern and central Illinois and occurs in the south in winter (Oberholser 1921). Two color types of fresh adult blue jay specimens-darker blue (especially breast, crown, and back) and lighter blue - are readily distinguishable among Illinois specimens, but we have not worked out size relationships.

Pitelka's (1946) appeal that banders utilize plumage characteristics to determine the ages of jays that are banded in order to shed light on the relationship of migration to populations at different latitudes still needs consideration. 
Weights of winter (January-March) specimens of adult blue jays from southern Illinois were 91.7, 96.2, and $97.6 \mathrm{~g}$ for three males and 93.0 and $98.5 \mathrm{~g}$ for two females. An April specimen of an adult male weighed $90.6 \mathrm{~g}$, and a November specimen of an immature female weighed $102.0 \mathrm{~g}$. Clemans (1974) reported gross weight for "quite fat" blue jays that had died in captivity as $85.7 \pm 2.4 \mathrm{~g}$; for "wild birds" he reported $84.5 \pm 17.5 \mathrm{~g}$. A male blue jay collected in June by Hancock (1888) weighed $85.0 \mathrm{~g}$ and had a brain weight of $2.98 \mathrm{~g}$.

\section{CLARK'S NUTCRACKER (Nucifraga columbiana)}

This western species has been reported twice from Illinois, one shot 9 October 1894 in Cook County (Coale 1911) and another seen 8 May 1909 in Whiteside County (Maxwell 1921). Neither record can be verified. Though the Cook County specimen is not extant, the species was seen widely in the east in 1894 (Bohlen 1978).

\section{BLACK-BILLED MAGPIE}

\section{(Pica pica)}

The approximately 30 records of the magpie in Illinois suggest that the species is a rare winter visitor but one that can be expected some years. Kennicott (1853-1854) considered the bird not uncommon in winter in Cook County. Illinois records are clustered in the northeast (major population center) and in the far west (Fig. 7), where T.E. Musselman was an active observer for many years and secured a number of records. Most Illinois records fall between October and March, with one as early as mid-September (Kleen 1974b) and another as late as 16 May (Oberholser 1918). The records tend to come every two to four years with occasional runs of consecutive years (19341937, 1950-1951, 1962-1963, 1973-1975). Some Illinois magpies may be escaped captives, and the examination of specimens for telltale signs of "captivity wear" of plumage might help to determine their status. Most records refer to single birds, but at least one report notes two birds (Coale 1919). Du Mont (1935) referred to notable winter invasions in Iowa in 1924 and in 1934-1935. Magpies sometimes reach even far eastern states (De Vos 1964).

A few records were not plotted in Figure 7 because the specific locality was lacking or unknown to us: Cook County (Dunn 1895; Fawks 1967) and Vermilion County (Kleen 1982b).

\section{Black-Billed Magpie Illinois Records}

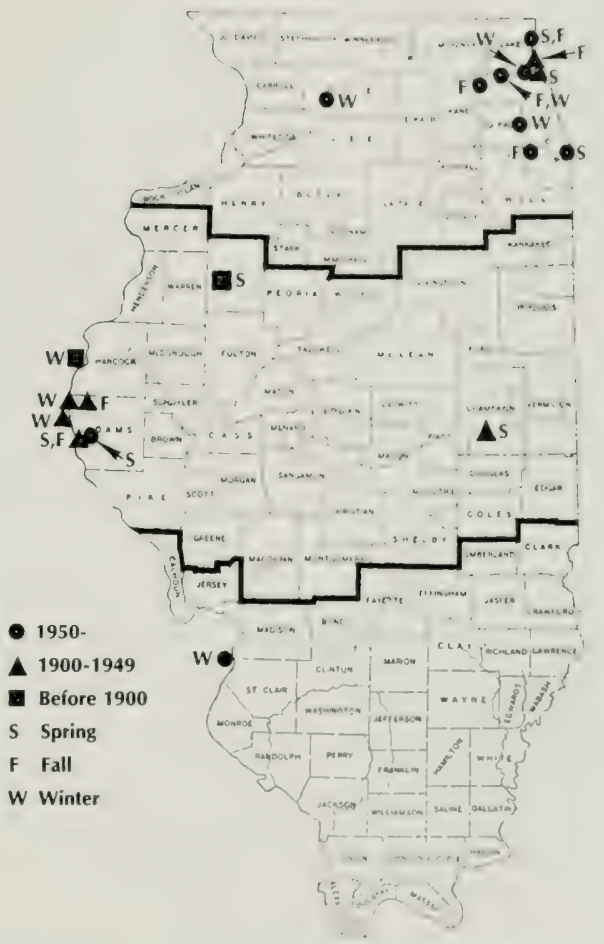

Fig. 7.-Distribution of records of the black-billed magpie in Illinois.

\section{AMERICAN CROW \\ (Corvus brachyrhynchos)}

(Fig. 8)

\section{Spring Migration}

A merican crows that breed south of $43^{\circ} \mathrm{N}$ latitude in eastern North America are largely sedentary (Black 1941). There is some influx to Illinois in fall and some exodus in spring of crows from more northern breeding areas (Fig. 9). Migration by Illinois nesters is not extensive, but some individuals move from northern and central to southern Illinois in late fall and winter (Fig. 10). The migration of crows, so far as it is known, 
is diurnal but has rarely been seen or counted in Illinois. Because crows are rangy, their migration flights may be difficult to distinguish from their local movements. Their migration is much like the jay's, passing along at least some of the same routes-major rivers and the Lake Michigan shore-but coming generally earlier in spring and later in fall.

W.W. Cooke (1888) stated that spring migration along the Mississippi River at St. Louis began about mid-March, though he also noted that the large crow roosts at St. Louis decreased rapidly after 4 March. We have seen crows migrating in Pope County on 8 March, and Watson and DeLaubenfels (1917) saw a migration in northeastern Illinois on 10 March. In nearby Indiana, migrations of crows $(1,500-2,000$ / day) were seen on six days in March and on 6 April (Nolan 1958). February migrations are to be expected (Ballou 1878) but apparently have not been observed in Illinois. Ekblaw and Ekblaw (1916) noted that crow migration was complete at Rantoul by 2 April.

Spring migration is more precipitous than fall migration. Black (1941) reported that crows banded in central Illinois in February and early March reached locations in Ontario and Michigan by 19-31 March. Crows banded in Illinois as late as 19-23 March were subsequently recovered in Michigan during the breeding season. Our counts also indicate that migrating crows are through Illinois by the end of April, with high counts in all regions falling from 100 or $200+$ per day to 20 or fewer. The direction of the crow's spring migration appears to change from east to west, with crows from eastern Illinois going northeast and crows from central and western Illinois going more directly north (Fig. 10).
Population densities suggest that favorite woody habitats for the crow in spring are bottomland forest and forest edge and shrub (Table 5). The figures are much like those for breeding densities and probably refer largely to the same population.

\section{Distribution}

American crows breed over much of North America except the extreme north and southwest (Fig. 11). In Illinois they surely nest in every county and perhaps in every township since they sometimes nest at the edges of towns. The large gaps in Figure 12 reflect inadequate field work. There are nest records for unspecified localities in Warren, Winnebago, and Whiteside counties (Illinois State Museum nest records; Thompson 1960).

\section{Nesting Habitats and Populations}

The crow has been considered a forest-edge species (Kendeigh 1982); a species of wood margins (Bjorklund and Deters 1972); and a dominant species of black oak forest (Gates 1911), of prairie (Gates 1911; Shackleford 1929), and of prairie thickets (Birkenholz 1975) - all true of the crow. Widmann (1907) noted that the crow shunned deep forest, an observation that is probably also true especially with regard to nest placement. A precise definition of habitat is made difficult by the bird's great ranginess and its lack of well-defined territory. It forages in many habitats far from the nest and does not defend a sizable area around the nest. Black (1941) observed that if territorial behavior exists in the crow, it is confined to the nest tree or to the female. He witnessed

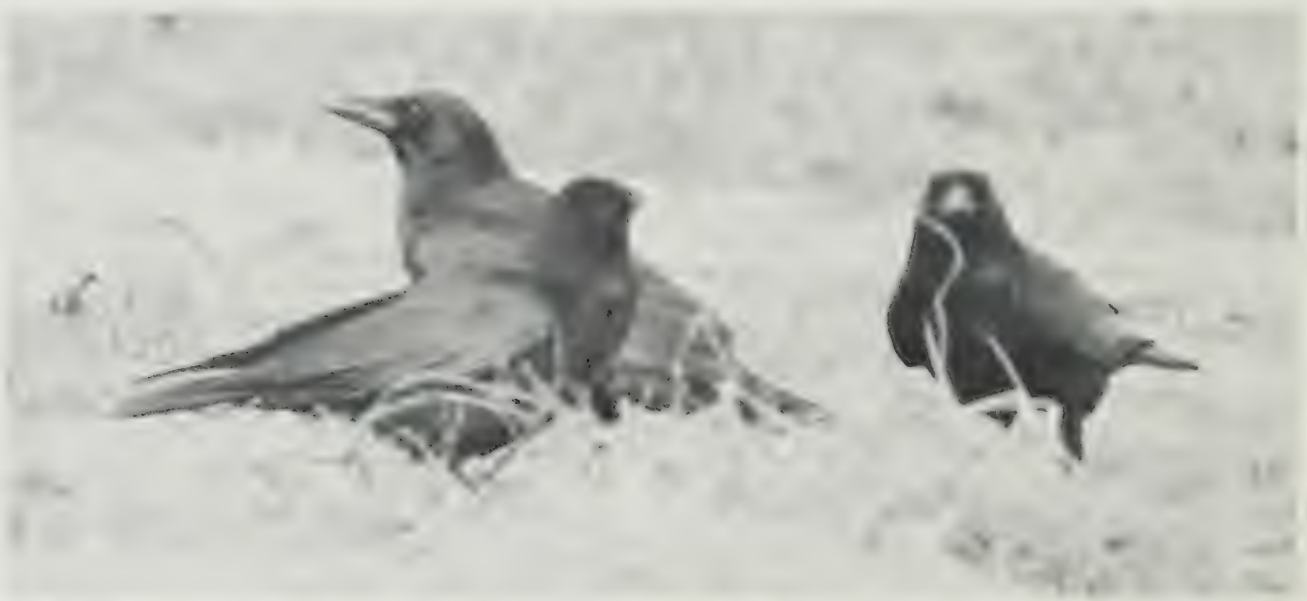

Fig. 8.-A typical trio of crows in early spring, Pope County, March 1986. 


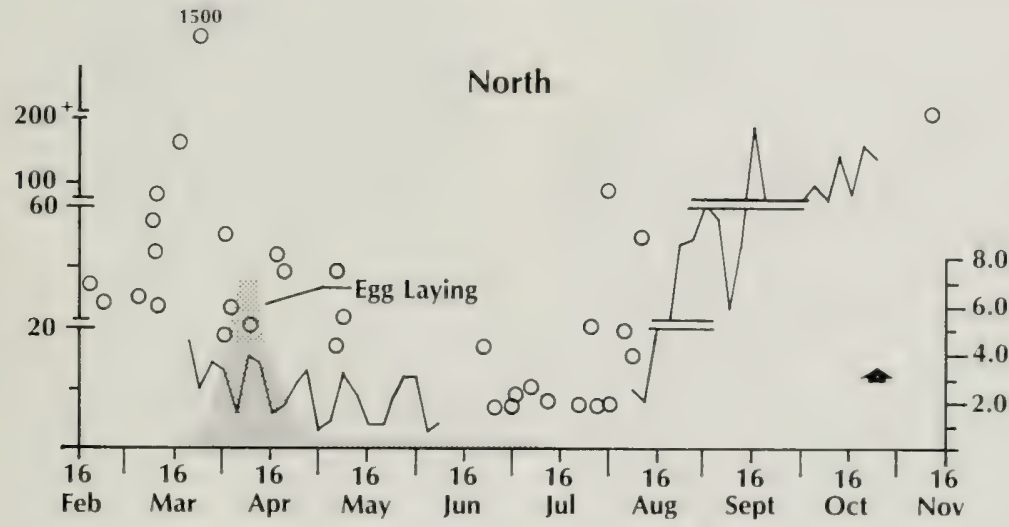

0े
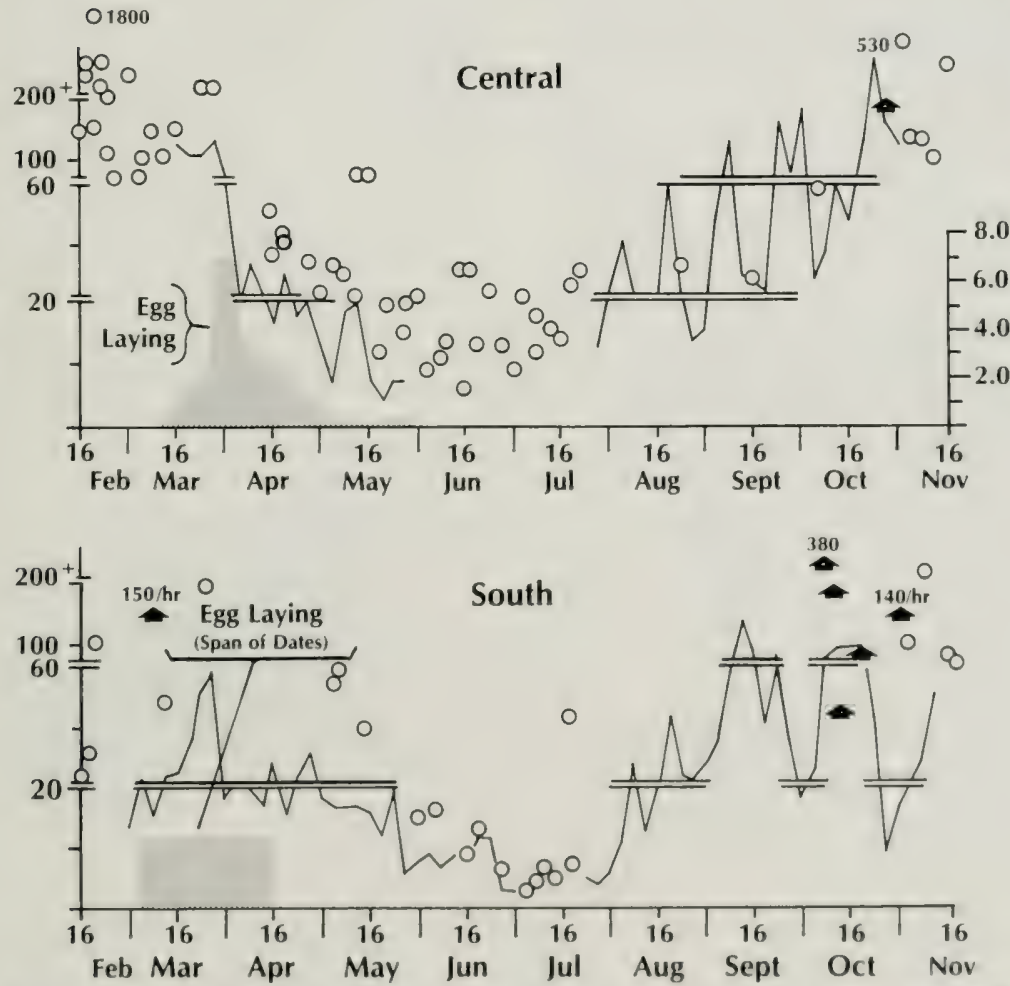

Fig. 9.-Egg-laying and migration seasons of the American crow in north, central, and south regions of lllinois (see Fig. 3 for region boundaries). Spring and fall lines show the highest daily count of each 4 days (1967-1970). Circles represent counts made in other years or by other observers. Shaded areas show the percentage of eggs laid on each date (north and central) and the span of dates during which egg laying has been recorded (south). Arrows represent counts of diurnal migrations. 
the defense of a nest only once in many hours of observation at 250 nests. Crows other than the nest mates were allowed to perch as close as 75 yards to the nest and to fly close to the nest tree.

The crow is perhaps the most clear-cut "generalist" of Illinois birds. We found crow densities to be generally higher in bottomland than in upland forest, a difference that was particularly striking in southern Illinois (Table 6). The more subtle difference in eastcentral Illinois probably reflects chiefly the shortage of habitat, since crows in that region may be pressed to use all the available woody habitat. Forest-edge and shrub habitat had relatively high populations in central Illinois and in the south in earlier years (1909) but not now. In general, counts for earlier years were higher than recent counts (Table 6), and we estimate that the crow population in Illinois declined 72 percent between 1907 and 1957 (R.R. Graber and J.W. Graber 1963). The growth of numerous pine plantations in recent decades, however, has provided much nesting habitat for the crow in southern Illinois. Essentially all open-field habitats are used by crows as foraging sites (Table 6).

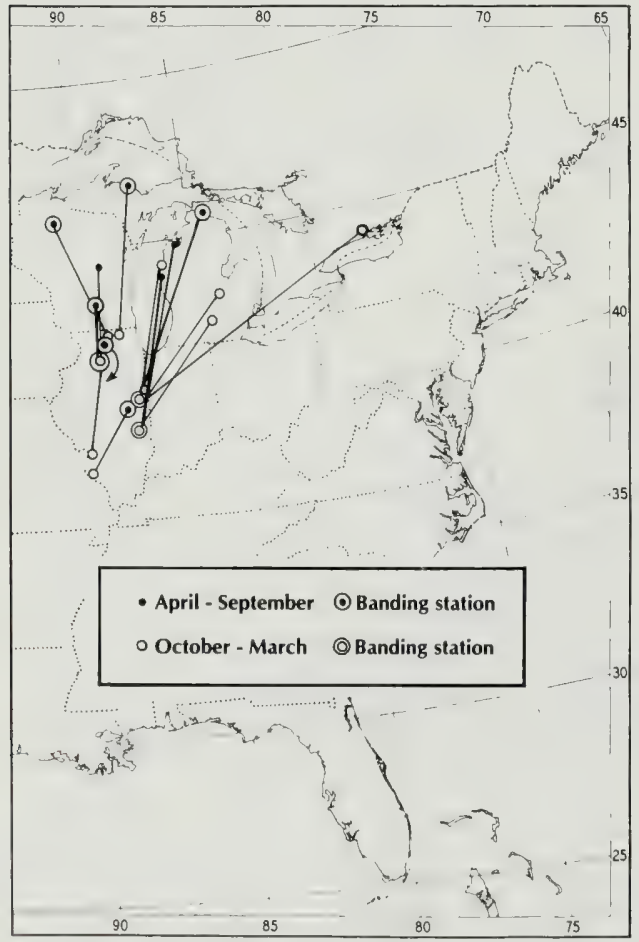

Fig. 10.- Recoveries of American crows that were either banded or recovered in Illinois.
Black (1941) provided an excellent summary of nest-site data in an intensively cultivated region (eastcentral Illinois). Of 253 nests found, 45 percent were located in trees in open fields, 34 percent in woodland, 14 percent in sparsely wooded pastures, and 7 percent in orchards, cemeteries, abandoned farm yards, tree plantations, and thickets. Nests in dense woods were within 40 yards $(36.6 \mathrm{~m})$ of the edge. Although nests were found in 28 species of trees, half were found in only 3 species-osage orange, American elm, and white oak, the species most prevalent in the area. Black believed that crows showed a preference for oaks and elms over the equally numerous maples in woodlands. Of 115 nests found in open farmland, $69(60 \%)$ were in osage orange (see also Alfred Gross's comments in Bent 1946). Other data on nest sites are summarized in Table 7. Most nests were in oaks, but the data slighted osage orange, especially in central Illinois, where authors did not always give numbers for that tree, noting only that it was a common nest tree for crows. Osage orange would surely have been a predominant species in open farmland. The "low pines" mentioned by Woodruff (1907) as breeding sites are not included in Table 7 because no numbers were given.

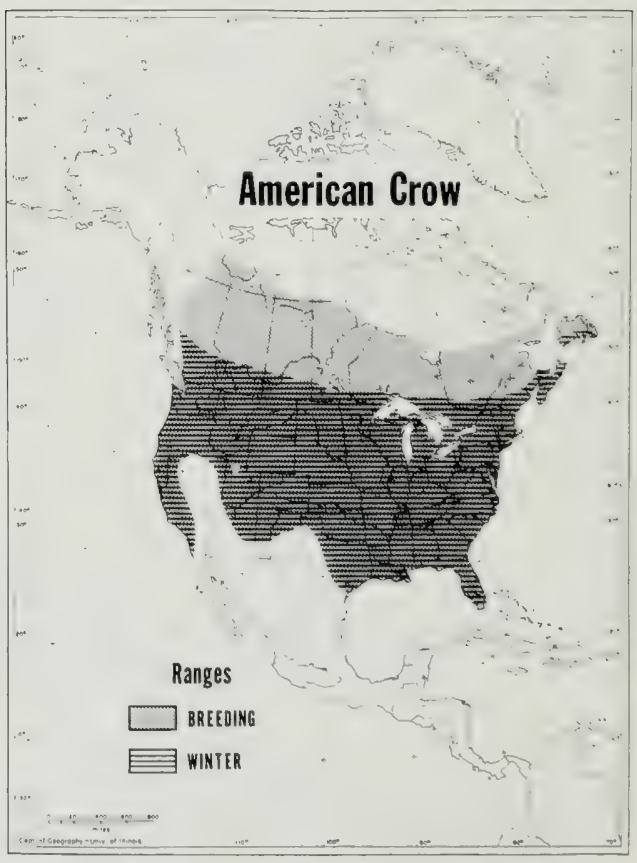

Fig. 11.-General distribution of the American crow. 
Heights of 90 nests in the northern region and 29 in the central region ranged from 8 to $50 \mathrm{ft}(2.4-15.2$ $\mathrm{m})$; heights averaged $29 \mathrm{ft}(8.8 \mathrm{~m})$ in the north and $25.6 \mathrm{ft}(7.8 \mathrm{~m})$ in the central region. Nest heights in Black's much larger sample ranged as high as $60 \mathrm{ft}$ $(18.3 \mathrm{~m})$ and averaged $24 \mathrm{ft}(7.3 \mathrm{~m})$ in open field habitat and $35 \mathrm{ft}(10.7 \mathrm{~m})$ in woodland, figures that reflect the general heights of trees in these habitats.

\section{Nesting Cycle}

Homing of nesting crows has not been demonstrated in Illinois, though juveniles have been recovered after a year near the nesting place (Bartel 1945). Apparently few adults have been banded in Illinois. The following notes are summarized mainly from Black's (1941) extensive work in central Illinois. Pairing of crows was not observed until early February and was accompanied by courtship flights involving (presumed) two males pursuing a female with much "cawing." Such flights were regularly seen from February into April, even after incubation was complete. Testes and ovaries of adults reached maximum size about the end of February or early March, with females developing slightly ahead of males. The development of the gonads of crows from southern Illinois was advanced 1 to 2 weeks ahead of those of birds from the north. Gonad development in juveniles was consistently behind that in adults, and males especially did not reach breeding condition in the first year, apparently not becoming sexually mature until the end of their second year. Yearlings (nonbreeders) comprise about 35 percent of the population at the start of the nesting season. Black observed courtship in which a male with wings partly spread hopped from branch to branch in the nest tree, uttering a ratting call. Copulation, which he witnessed twice, took place on the nest during early stages of incubation.

Of 97 nests observed by Black in 1938, only 1 was used again in 1939. Both mates carried nest material to some of these nests, but whether both birds took part in the actual nest building was not determined. Burns (1895) learned that nest construction took from 1 to 3 weeks, depending on the weather. Building time for second nests (i.e., after nest failure) was 6 to 8 days. Nests constructed early in the season were usually larger and more solidly constructed than later nests. Nearly all nests had a base shell of dead twigs and a lining of grapevine bark. Nests in open field habitats, where twigs were scarce, included as much as $\mathbf{5 0}$ percent herbaceous material. Materials used in the outer shell included sticks as thick as $\$ / 4$ in (1.9 $\mathrm{cm}$ ), grass, weed (milkweed) stems, corn husks and stalks, binder twine, straw, hay, oak leaves, bark, rootlets, Indian hemp (Strode 1889a), paper, and mud; lining materials included grass; inner fibers of maple bark; the bark of grape, cottonwood, and willow; cornhusks and stalks; twine; horse and cow hair; fur of skunk, rabbit, and squirrel; fleece of sheep; straw; moss; oak leaves; and feathers (Loucks, unpublished 1890; Silloway 1906a; Sanborn and Goelitz 1915). The same materials (outer shell and lining) were listed for all regions of the state. Measurements-range and (mean)-for six crow nests from northern Illinois were as follows: outside diameter, 14-30 in (20.5 in); outside depth, 12 in (no variation); inside depth, 4-8 in (6 in); and inside diameter, $8-10$ in (9.3 in). At least once, crows nested in an old hawk's nest (Silloway, unpublished 1923); for three seasons, crows nested in a tree cavity in a Knox County woods (Bent 1946).

TABLE 5.-Spring and fall population densities of the American crow in lllinois (1979-1981).

\begin{tabular}{|c|c|c|c|c|c|}
\hline Season and Habitat & $\begin{array}{l}\text { County } \\
\text { or } \\
\text { Region }\end{array}$ & $\begin{array}{c}\text { Number } \\
\text { of } \\
\text { Censuses }\end{array}$ & $\begin{array}{c}\text { Cumulative } \\
\text { Hectares } \\
\text { Censused }\end{array}$ & Maximum & Mean \\
\hline \multicolumn{6}{|l|}{ Spring (23 March-31 May) } \\
\hline Mature bottomland forest & Piatt (C) & 12 & 241 & 16.1 & 9.2 \\
\hline Mature bottomland forest & Johnson (S) & 21 & 436 & 19.0 & 4.8 \\
\hline Mature upland forest & Piatt (C) & 15 & 316 & 7.9 & 1.9 \\
\hline Forestedge and shrub & Pope (S) & 20 & 394 & 8.1 & 1.4 \\
\hline Loblolly pines & Pope (S) & 12 & 214 & 9.1 & 4.2 \\
\hline \multicolumn{6}{|l|}{ Fall (1 August-3 November) } \\
\hline Mature bottomland forest & Piatt (C) & 27 & 541 & 229.8 & 27.7 \\
\hline Forest edge and shrub & Pope (S) & 24 & $4 \times 4$ & 7.8 & 1.4 \\
\hline Loblolly pines ( $1979-1980 \mathrm{only})$ & Pope (S) & 13 & 228 & 9.0 & 2.0 \\
\hline
\end{tabular}


In northern Illinois, B.T. Gault (unpublished notes 1884-1927) first observed the mating of crows on 5 March, nest building on 14 March, and a bird on a nest 20 March. At Deerfield, crows had partial or complete clutches, 25-28 March (Mooney 1930). In central Illinois, Black first observed pairing in early February and nest building in late February. The earliest egg date was 16 March (Fig. 9). A nest with eggs on 25 February at Urbana (Anonymous 1917) would be very unusual and is not plotted in Figure 9. Because of nest failures, mating and nest building might be seen at any time during the breeding season. Based on available data, peak egg production comes between 28 March-8 April in the central region and 1-16 April in the north (Fig. 9); no comparable data are available for the south.

Eggs vary from blue-green to olive-green (rarely buffy) and are marked with irregularly shaped blotches and dots in shades of browns and grays.

\section{American Crow Breeding Records}

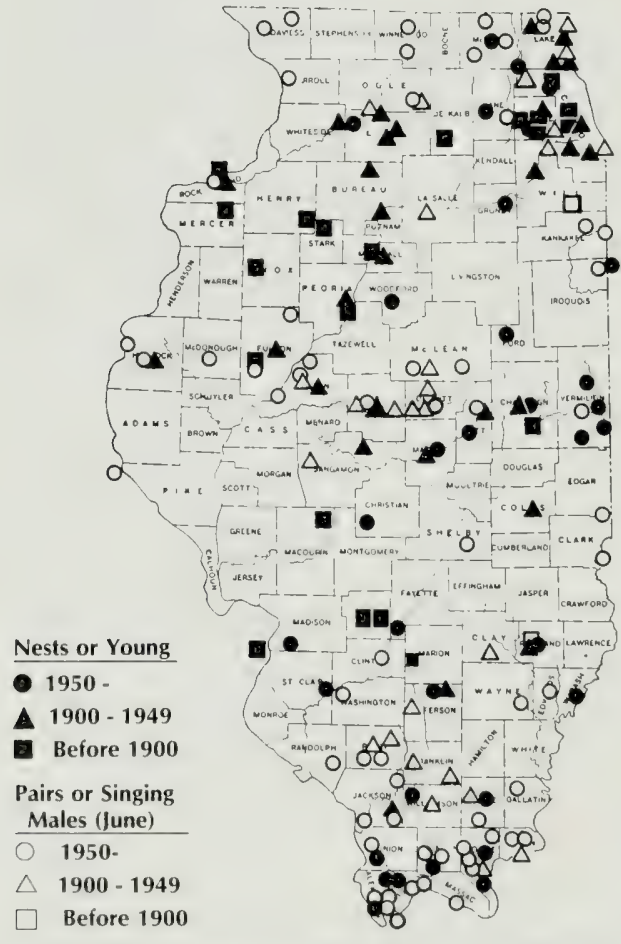

Fig. 12.-Breeding records of the American crow in Illinois.
These blotches usually occur on the large end of the egg but are sometimes evenly distributed. Eggs are usually laid one per day. Measurements for 132 American crow eggs from Illinois and adjacent states ranged from 1.95 by 1.27 in to 1.51 by 1.13 in and averaged 1.68 by 1.18 in (Burns 1895).

Clutch data from the literature and from museum collections showed no significant difference between northern Illinois (100 nests) and central Illinois (37 nests). For the combined sample, clutches were $7 \mathrm{eggs}$, 4 percent; 6 eggs, 17 percent; 5 eggs, 50 percent; 4 eggs, 19 percent; 3 eggs, 8 percent; and 2 eggs, 2 percent; the mean was 4.8 eggs. Black's (1941) data (not included above) were similar. In his 2-year sample of 72 nests, about 50 percent had 5 eggs; the mean for all nests was 4.5 eggs. A clutch of 9 eggs (Barnes 1914) is abnormal for the crow.

Black determined that incubation was by the female only, that it usually began with the third egg laid, and that it required 19 days. By 20 April, 40 percent of the nests observed by Black contained young ( $60 \%$ had eggs); by 30 April, 68 percent had young. The incubating bird typically sat for long periods and was away from the nest only briefly. Early in the incubation, attentive periods were very different at two nests. At one, the average attentive period was $14 \mathrm{~min}$ and the inattentive period, $4 \mathrm{~min}$; at the other, the attentive period was $94 \mathrm{~min}$ and the inattentive period, $4 \mathrm{~min}$. The incubating bird at each of these nests was fed on the nest by the male. At two nests, Black believed that two females attended the nest and shared in the incubation. At that time (1941), nothing was known about "nest helpers," and Black may have been one of the first to observe such behavior.

According to Black's data, eggs hatched over a period of 2-3 days, and hatching at most nests came during the third week in April. Females did all brooding. For young 2-6 days of age, attentive periods averaged $20 \mathrm{~min}$ and inattentive periods, $25 \mathrm{~min}$. Young 10-11 days old were not brooded. During early nestling life, both parents fed the young. Between 0500 and $1900 \mathrm{CST}$, the average interval between feedings was $35 \mathrm{~min}$. Young were not fed from about 1200 to about $1500 \mathrm{CST}$, and the fastest rates of feeding were around 1100 and $1700-1800$ CST.

Both Black (1941) and Parmalee $(1949,1952)$ provided data on growth rates of nestlings. The eyes opened at about 11 days, and fear developed at about 14. The young remained in the nest 24-30 days but depended on adults for food for another 2-3 weeks. After a month, the young were feeding themselves by foraging on the forest floor. Three broods observed by Black remained in their "home" wood lots for the first 6 weeks after leaving their nests. Typically, broods tended to stay together even after becoming more or 
TABLE 6.-Summer populations of American crows in various Illinois habitats.

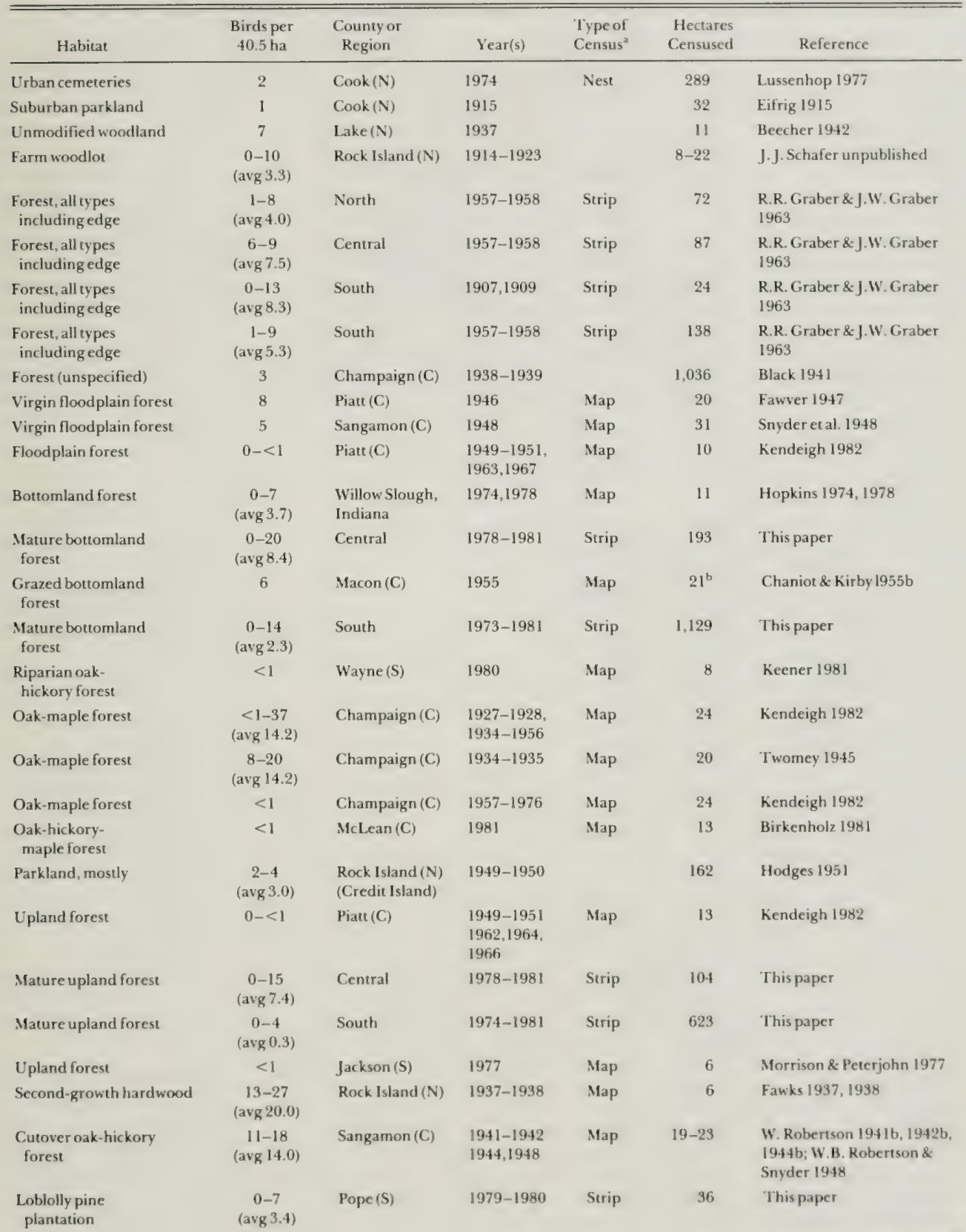


TABLE 6.-continued.

\begin{tabular}{|c|c|c|c|c|c|c|}
\hline Habitat & $\begin{array}{c}\text { Birds per } \\
40.5 \text { ha }\end{array}$ & $\begin{array}{l}\text { County or } \\
\text { Region }\end{array}$ & Year(s) & $\begin{array}{l}\text { Type of } \\
\text { Census }^{a}\end{array}$ & $\begin{array}{r}\text { Hectares } \\
\text { Censused }\end{array}$ & Reference \\
\hline $\begin{array}{l}\text { Shrub, including } \\
\text { edge shrub }\end{array}$ & $\begin{array}{c}0-8 \\
(\operatorname{avg} 5.4)\end{array}$ & South & 1907,1909 & Strip & 23 & $\begin{array}{l}\text { R.R. Graber \& J.W. Graber } \\
1963\end{array}$ \\
\hline $\begin{array}{l}\text { Shrub, including } \\
\text { edge shrub }\end{array}$ & $\begin{array}{c}4-8 \\
(\operatorname{avg} 5.4)\end{array}$ & Central & $1980-1981$ & Strip & 38 & This paper \\
\hline Pasture & 6 & North & 1909 & Strip & 78 & $\begin{array}{l}\text { R.R. Graber \& J.W. Graber } \\
1963\end{array}$ \\
\hline Pasture & $\begin{array}{c}2-6 \\
(\operatorname{avg} 3.4)\end{array}$ & Central & 1907,1909 & Strip & 179 & $\begin{array}{l}\text { R.R. Graber \& J.W. Graber } \\
1963\end{array}$ \\
\hline Pasture & $\begin{array}{c}0-2 \\
(\operatorname{avg~1.7)}\end{array}$ & Central & $1957-1958$ & Strip & 69 & $\begin{array}{l}\text { R.R. Graber \& J.W. Graber } \\
1963\end{array}$ \\
\hline Pasture & 1 & South & 1907,1909 & Strip & 357 & $\begin{array}{l}\text { R.R. Graber \& J.W. Graber } \\
1963\end{array}$ \\
\hline Ungrazed grass & $\begin{array}{c}0-10 \\
(\operatorname{avg} 8.5)\end{array}$ & North & $1957-1958$ & Strip & 24 & $\begin{array}{l}\text { R.R. Graber \& J.W. Graber } \\
\text { I963 }\end{array}$ \\
\hline Swampy prairie & $\begin{array}{c}6-15 \\
\text { (avg } 10.3)\end{array}$ & Sangamon (C) & $\begin{array}{l}1941-1942 \\
1944\end{array}$ & Map & 26 & $\begin{array}{l}\text { W. Robertson 1941a, 1942a, } \\
\text { 1944a }\end{array}$ \\
\hline Prairie & 0.4 & Champaign(C) & 1938 & Nest & 6,993 & Black 1941 \\
\hline Grassland & $\begin{array}{c}0-4 \\
(\operatorname{avg} 1.3)\end{array}$ & South & $1978-1979$ & Strip & 150 & This paper \\
\hline Mixed hayfields & $\begin{array}{c}0-15 \\
(\operatorname{avg} 8.0)\end{array}$ & Central & 1907,1909 & Strip & 51 & $\begin{array}{l}\text { R.R. Graber \& J.W. Graber } \\
1963\end{array}$ \\
\hline Marsh & $\begin{array}{c}0-3 \\
(\operatorname{avg} 2.3)\end{array}$ & North & $1957-1958$ & Strip & 35 & $\begin{array}{l}\text { R.R. Graber \& J.W. Graber } \\
1963\end{array}$ \\
\hline Red clover & $\begin{array}{c}0-12 \\
(\operatorname{avg} 8.7)\end{array}$ & Central & 1907,1909 & Strip & 19 & $\begin{array}{l}\text { R.R. Graber \& J.W. Graber } \\
1963\end{array}$ \\
\hline Alfalfa & 2 & South & $1957-1958$ & Strip & 20 & $\begin{array}{l}\text { R.R. Graber \& J.W. Graber } \\
1963\end{array}$ \\
\hline Fallow (forbs and grass) & $\begin{array}{c}1-2 \\
(\operatorname{avg} 1.6)\end{array}$ & South & 1907,1909 & Strip & 129 & $\begin{array}{l}\text { R.R. Graber \& J.W. Graber } \\
1963\end{array}$ \\
\hline Wheat & $\begin{array}{c}0-1 \\
(\operatorname{avg} 0.6)\end{array}$ & Central & 1907,1909 & Strip & 68 & $\begin{array}{l}\text { R.R. Graber \& J.W. Graber } \\
1963\end{array}$ \\
\hline Oats & 5 & North & 1909 & Strip & 98 & $\begin{array}{l}\text { R.R. Graber \& J.W. Graber } \\
1963\end{array}$ \\
\hline Oats & $\begin{array}{c}<1 \\
(\operatorname{avg} 0.5)\end{array}$ & Central & 1907,1909 & Strip & 241 & $\begin{array}{l}\text { R.R. Graber \& J.W. Graber } \\
1963\end{array}$ \\
\hline Oats & $\begin{array}{c}0-2 \\
(\operatorname{avg} 1.6)\end{array}$ & South & 1907,1909 & Strip & 74 & $\begin{array}{l}\text { R.R. Graber \& J.W. Graber } \\
1963\end{array}$ \\
\hline Corn & 2 & North & 1909 & Strip & 142 & $\begin{array}{l}\text { R.R. Graber \& J.W. Graber } \\
1963\end{array}$ \\
\hline Corn & $\begin{array}{c}0-<1 \\
(\operatorname{avg} 0.2)\end{array}$ & North & $1957-1958$ & Strip & 249 & $\begin{array}{l}\text { R.R. Graber \& J.W. Graber } \\
1963\end{array}$ \\
\hline Corn & $\begin{array}{c}2-3 \\
(\text { avg } 2.5)\end{array}$ & Central & 1907,1909 & Strip & 468 & $\begin{array}{l}\text { R.R. Graber \& J.W. Graber } \\
1963\end{array}$ \\
\hline Corn & $\begin{array}{c}0-1 \\
(\text { avg } 0.6)\end{array}$ & South & 1907,1909 & Strip & 398 & $\begin{array}{l}\text { R.R. Graber \& J.W. Graber } \\
1963\end{array}$ \\
\hline Corn & $\begin{array}{c}0-4 \\
(\operatorname{avg} 2.3)\end{array}$ & South & $1957-1958$ & Strip & 105 & $\begin{array}{l}\text { R.R. Graber \& J.W. Graber } \\
1963\end{array}$ \\
\hline Soybeans & 3.6 & South & 1979 & Strip & 45 & This paper \\
\hline Plowed ground & 2 & South & $1957-1958$ & Strip & 56 & $\begin{array}{l}\text { R.R. Graber \& J.W. Graber } \\
1963\end{array}$ \\
\hline
\end{tabular}

${ }^{a}$ Strip censuses calculated as cumulative hectares.

${ }^{b}$ Represents an acreage correction by Kirby and Chaniot (see Kirby \& Chaniot 1957). 
less independent. The first fledged young were seen 5 May, but a majority left the nest in late May. Nests that fledge only one young (Gammell 1928) are probably not uncommon. A single nesting cycle from the onset of nest building to the fledging of young is about 53-59 days. Judging from the laying curve, one brood per year is probably the rule in Illinois.

Black's (1941) data indicated that 53 percent of the nests studied produced at least one young to banding age. His largest sample (132 nests) with more complete histories fledged, on average, 2.4 young per nest; however, since these were nests with incomplete histories, the success rate may have been less than stated. Black also found that most nest losses occurred during the incubation period before foliage developed suffi-

TABLE 7.-Nest trees of American crows in the three regions of Illinois, 1880-1975. Scientific names are included only when provided in the original source.

\begin{tabular}{|c|c|c|c|}
\hline \multirow[b]{2}{*}{ Species } & \multicolumn{3}{|c|}{ Number of Nests } \\
\hline & North & Central & South \\
\hline Oaks (Quercussp.) & 39 & 11 & 1 \\
\hline Black oak & 4 & - & - \\
\hline Buroak & 1 & - & - \\
\hline $\begin{array}{l}\text { Postoak } \\
\text { (Quercus stellata) }\end{array}$ & - & - & 2 \\
\hline Red oak & 4 & - & - \\
\hline White oak & 1 & 6 & - \\
\hline Elm & 7 & 2 & 2 \\
\hline Willow & 10 & - & - \\
\hline Hard maple & 3 & 1 & - \\
\hline Maple & - & - & 1 \\
\hline $\begin{array}{l}\text { Silver maple } \\
\text { (Acersaccharinum) }\end{array}$ & - & 1 & - \\
\hline Boxelder & 1 & - & - \\
\hline Pines & 5 & 1 & - \\
\hline Loblolly pine (Pinus taeda) & - & 一 & 2 \\
\hline White pine & 1 & - & - \\
\hline Spruce & 3 & - & - \\
\hline Evergreen & 1 & - & - \\
\hline $\begin{array}{l}\text { Red cedar } \\
\text { (Juniperus virginiana) }\end{array}$ & - & - & 1 \\
\hline Ash & 3 & - & - \\
\hline Blackash & 1 & - & - \\
\hline White ash & 1 & - & - \\
\hline Crabapple & 4 & - & - \\
\hline Catalpa & 2 & - & - \\
\hline Chokecherry & 1 & - & - \\
\hline Hackberry & 1 & - & - \\
\hline Cottonwood & 1 & 3 & - \\
\hline $\begin{array}{l}\text { Osage orange } \\
\text { (Maclura pomifera) }\end{array}$ & 1 & 5 & - \\
\hline Basswood & 1 & - & - \\
\hline Apple & 1 & 1 & - \\
\hline Black walnut & - & 1 & - \\
\hline Total & 97 & 32 & 9 \\
\hline
\end{tabular}

ciently to conceal the nests. Shooting of crows at the nest was a common practice then. Modern comparative data on nesting success are needed. Black calculated that 53 percent of the eggs laid produced young of banding age, that 23 percent of the birds survived their first year, and that one bird survived through the seventh year. The major postfledging mortality was due to shooting, to the dynamiting of birds at roosts, and to disease. Black noted that 94 percent of the recoveries of banded birds resulted from shooting or trapping. Of 77 nestling crows banded by Bartel (1976), all but 1 of the 15 recovered had been shot. The oldest banded crows for which we have found records in Illinois are one bird 9 years, 2 months-still alive at that time (Periodic Report by Region of Banding-234 for 14 December 1983) and another 10 years, 3 months-shot dead (Anonymous 1936).

In June, the beginning of the molt becomes apparent as crows everywhere in the state lose feathers. By August, some young birds begin to wander, but migration comes later.

\section{Fall}

There is little evidence of much emigration of crows from Illinois. Our observations of migrating crows in October and November, especially in southern Illinois, account for a relatively small number of birds (Fig. 9) and more closely coincide in time with the immigration of birds to Illinois. $A$ crow banded in northern Michigan in June of 1956 was killed 21 October of the same year at Harvard, Illinois (Weiland 1960). In central Illinois, Hall (1931) saw crows migrating ( $10,000 / 10$ days) in October, and Kleen (1976) reported a flight on 29 October. These records and ours (Fig. 9) coincide with the roost data given below and indicate that most of the immigration occurs in October and early November. The migration can, however, extend well into December, as C. Nixon (unpublished 1973) observed at Monticello, where he saw several hundred crows on 20 December flying southeast in a long loose string with only about 20 at a time in view. (See also band recoveries of Illinois breeders in southwestern Illinois in winter, Figure 10.) More northern birds come to Illinois for the winter from Michigan, Wisconsin, and Ontario (Fig. 10). Eifrig (1919) observed a pattern of crow migration around the south tip of Lake Michigan in which birds from the west side of the lake turned southeastward whereas those coming down the east side turned southwestward. It has not been determined whether or not this pattern is a regular feature of the crow's migration.

In central Illinois, the habitat preference of crows in fall was much like that in spring, with bottomland forest and forest edge and shrub particularly favored. In the south, densities were fairly uniform, with 
slightly higher densities in upland forest. In the central region, densities were notably higher in fall than in spring, a difference not found in the south (Table 5). Even in winter, population densities were relatively low in the south (Table 8).

In our counts, the spring-to-fall ratio of crows was about 1 to 6 in the north, a ratio that could be explained by the arrival of migrants from further north. In the central region, more crows were found on the east as opposed to the west side of the state in spring; in the fall, greater numbers of crows were found on the west side of Illinois. Thus the spring-to-fall ratio was about even ( 1 to 1 ) in the east but about 1 to 4 in the west. The spring-to-fall ratio in our census transects for east-central Illinois was 1 to 3 . In the south, the ratio was about 1 to 2 ( 1 to 1 in the transects). When we compared counts for April-early May (after most spring migration) with counts for August-early September (before most fall migration) as an indication of local productivity, the ratios were 1 to 3.6 in the north, 1 to 1.7 in the central region, and 1 to 2.2 in the south. Black's productivity data, an average of 2.4 young per nest, would be the potential equivalent of an April-to-August ratio of 1 to 2.2 crows. On the basis of 10,832 specimens, Black (1941) found that immatures comprised 27 percent of the winter crow population in January 1938 and 36 percent in 1939 , the rough equivalents of 1 to 1.3 and 1.5 when expressed as spring-to-fall ratios. The figures show a considerable fall from August numbers, but high losses are expected among songbirds in the early postfledging months, and the figures are probably within reason. The observations are complicated by migration, the influx of northeastern birds in winter, and the possibility (probability) of segregation of age groups with latitude. The crow was one of the few species to in- crease in population from late December to February during a severe winter (J.W. Graber and R.R. Graber 1979); however, the February censuses probably caught the beginning of spring migration.

\section{Roosts}

Both W.W. Cooke (1888) in the south and Black (1941) in the central region observed that the number of crows at roosts began to increase in September, and roosts were well established in mid- or late October. Although local breeders may begin to use roosts during the summer, especially in August, the roosts reached maximum size in late November or early December. Roosts have been located in both upland (especially oak) and bottomland (willow-cottonwood) woods and in plantations of various trees, but especially in osage orange hedges in farm areas and evergreen plantings wherever they may be. Catalpa groves were commonly used but whether out of proportion to their availability is not known. Crows have a long history of roosting in towns and cities (Table 9), and we believe that this tendency is increasing.

When we attempted in 1982 to locate roosts in east-central Illinois that existed in the $1930 \mathrm{~s}$, we found the nearest occupied roosts to be in towns where numbers of roosting crows were less than 10 percent of the 1938 population (Table 9). Most of the roosts were gone because osage orange hedges-the principal roost sites in the $1930 \mathrm{~s}$ - had been removed. The nearest remaining sites that are reasonably suitable in this intensively cultivated area are in towns. The tenacity of crows to roost sites is amazing. In some places crows are subjected to strenuous harassment from human residents. Crows that roosted in Flatville, Illinois, would sometimes wait until 0100 CST before coming to the roost trees because citizens had made

TABLE 8.-Winter populations of American crows in various Illinois habitats.

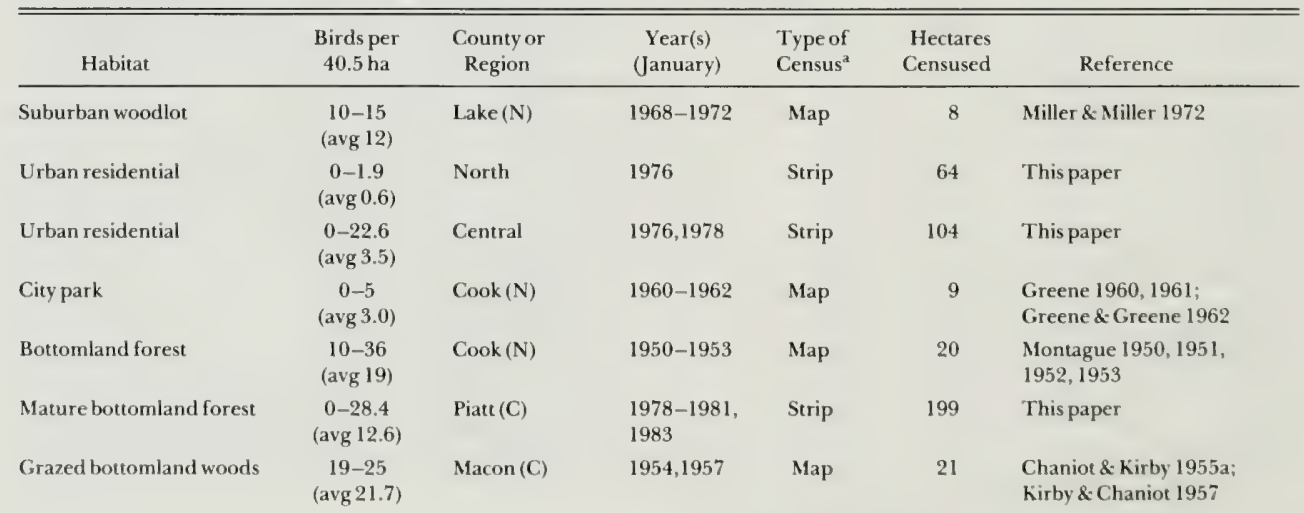


TABLE 8.-continued.

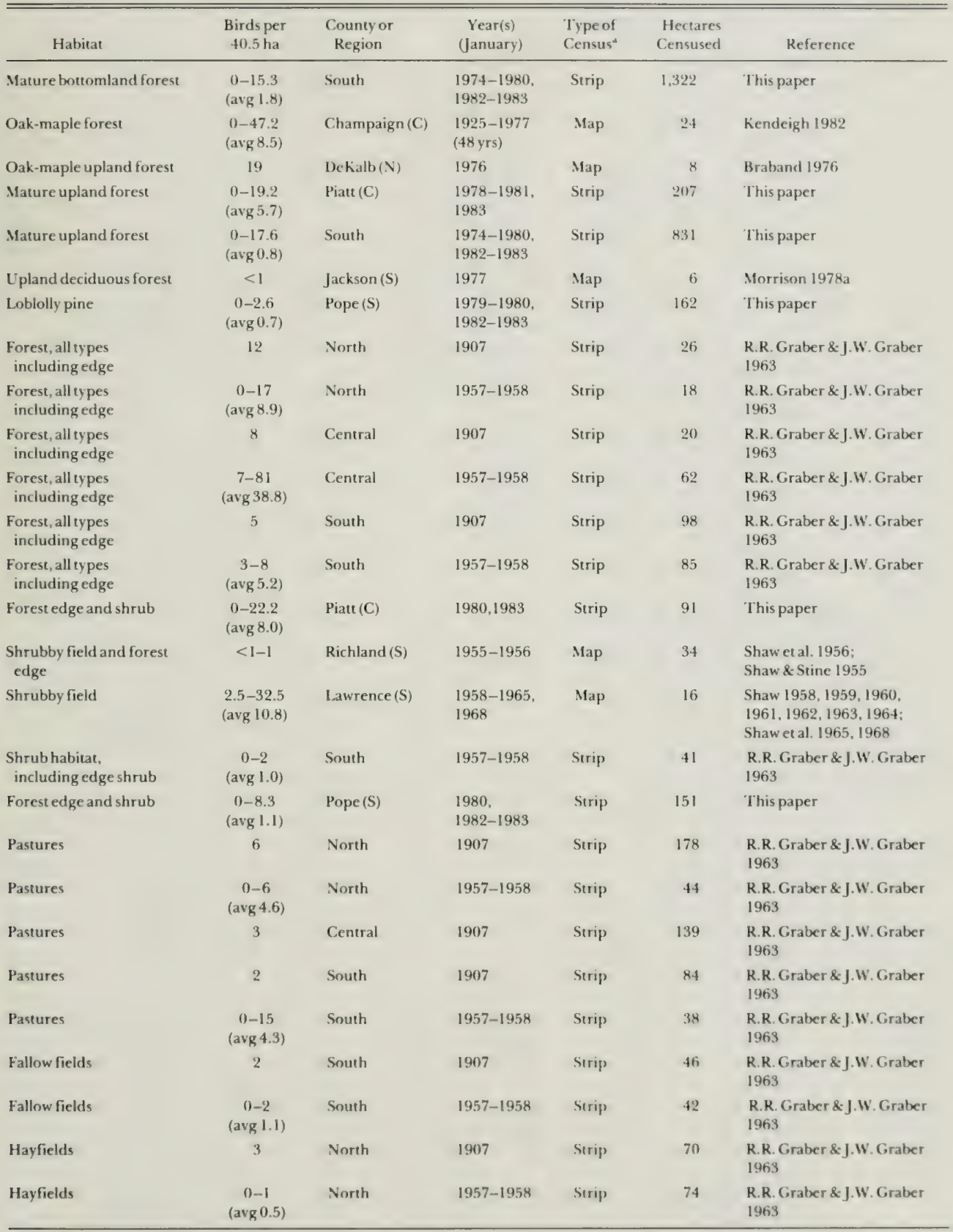

${ }^{2}$ Strip censuses calculated as cumulative hectares. 
TABLE 9.-Crow roosts used mainly in winter in Illinois, listed by Black (1941) and subsequent authors. Listing is north to south with counties in each region in alphabetical order.

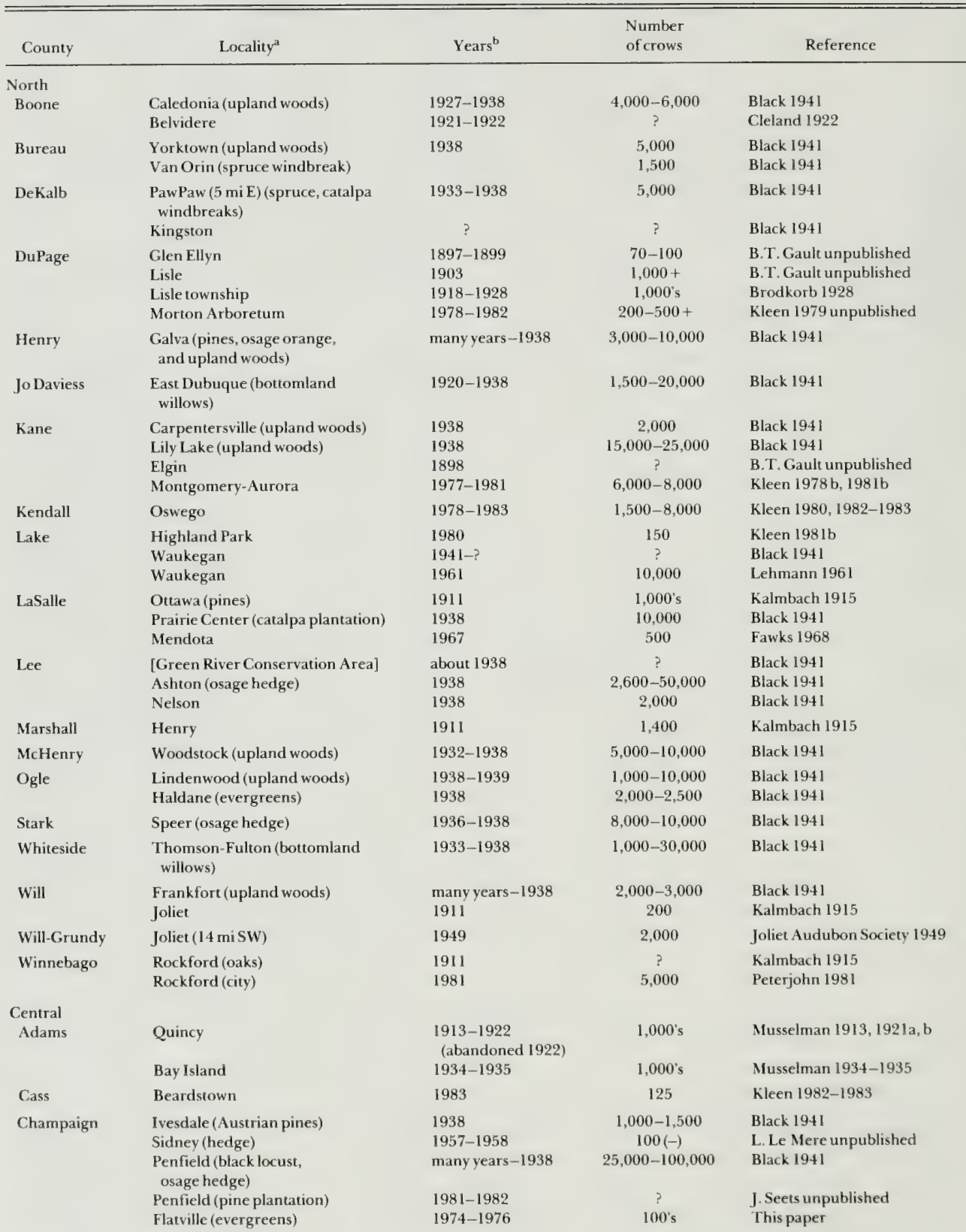


TABLE 9.-continued.

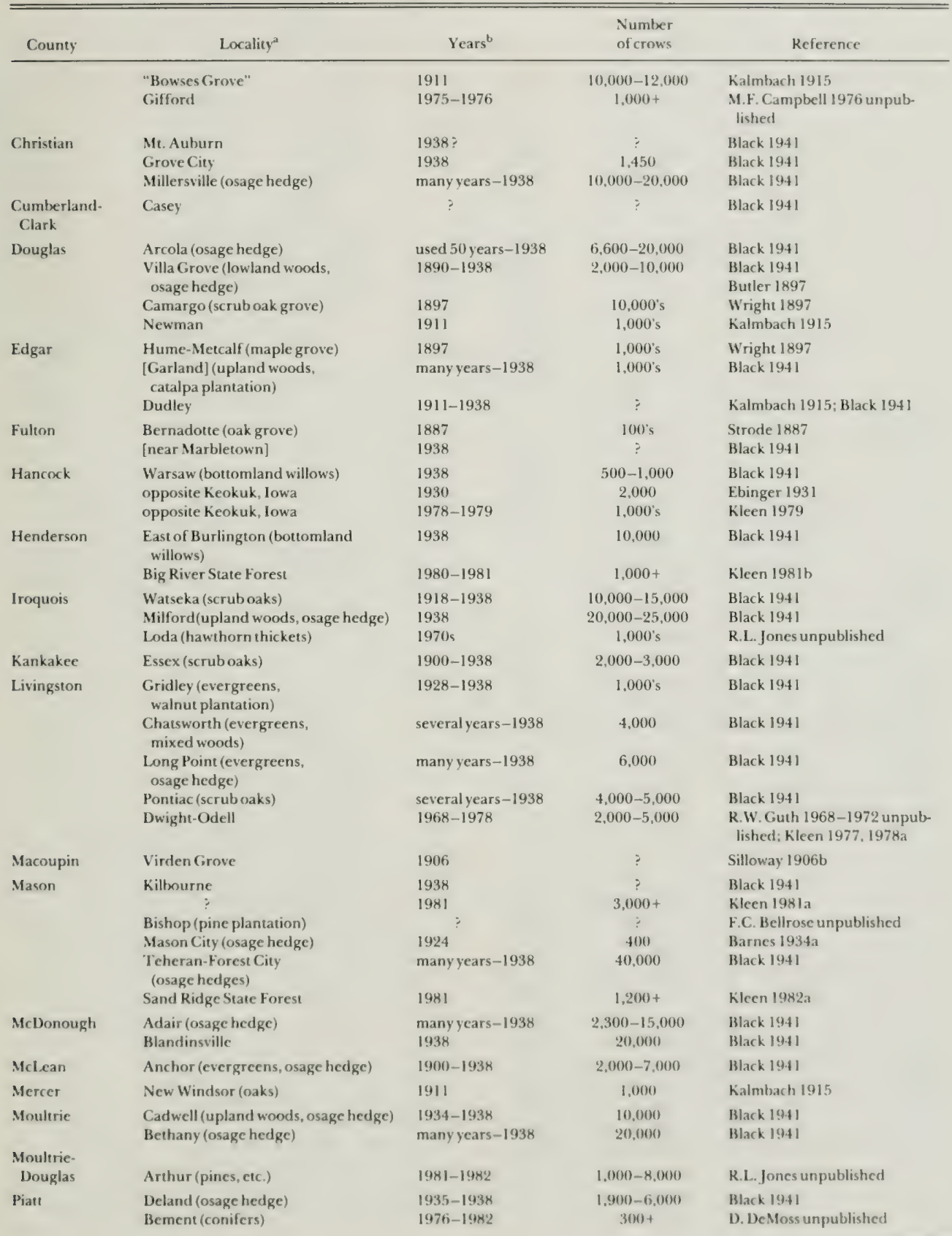


TABLE 9.-continued.

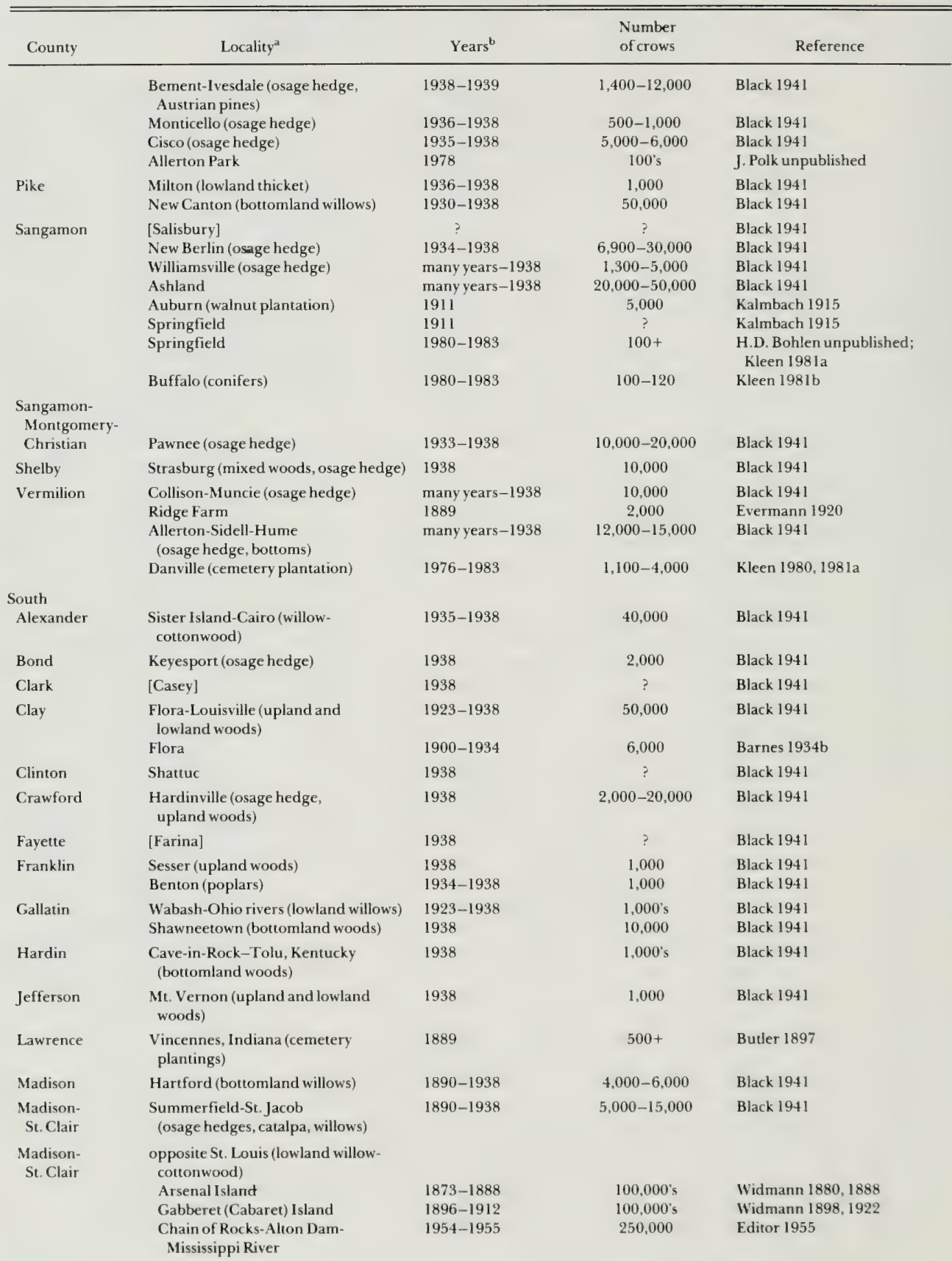


TABLE 9.-continued.

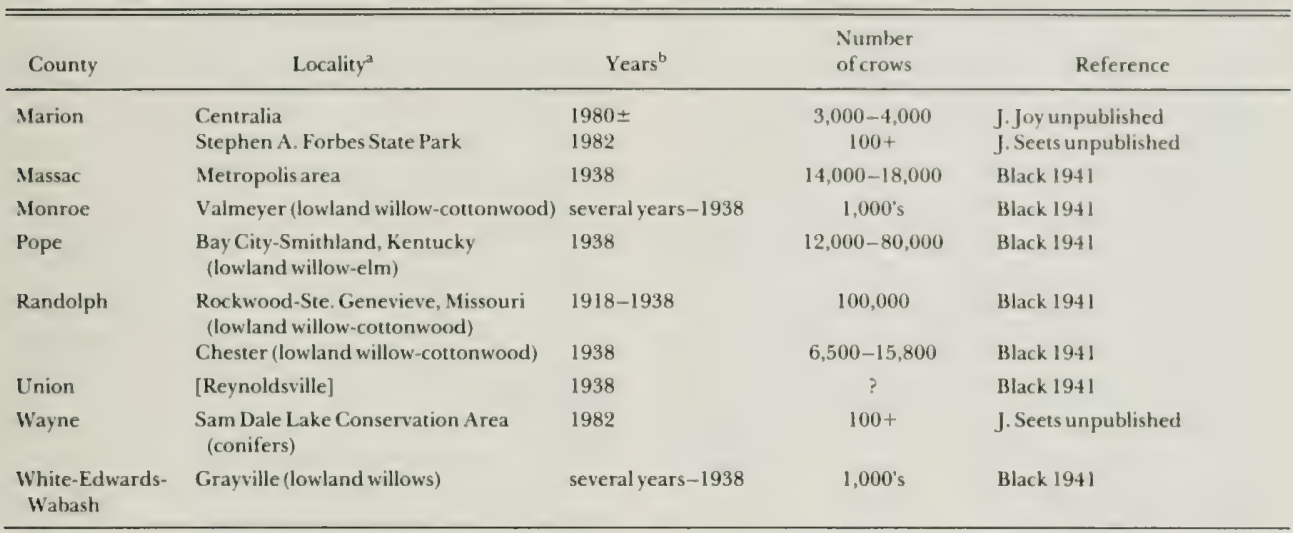

acalities in brackets were provided by us, not by the original authors, i.e., the site as nearly as we could determine it.

bears listed are the last for which there are data, not necessarily the last years roosts were used, e.g., 1938 for Black (1941).

concerted efforts to keep them away. Despite the efforts, the roost existed for a number of years. Discrete roosts have been deserted after heavy shooting (Hodges 1954). Crows begin to arrive at very large roosts as early as $1300 \mathrm{CST}$ (Widmann 1888) but more typically at about 1600 CST. Black (1939) and Musselman (1913) noted a relationship between low winter temperatures and the number of crows coming to large roosts. Generally, crows spend some time at staging areas near the roost before settling in the areas where they spend the night. Within a general area, the roost may be moved from tree to tree from time to time, but the general roosting area may be in use for 50 years or more (Table 9). A well-defined feeding area with about a 20 -mile radius surrounds each roost (Black 1939; W.W. Cooke 1883).

No complete survey of crow roosts has been made in Illinois since Black (1941). Although we have added such records as we have to his list (Table 9), a comprehensive statewide study is needed. Kalmbach (1918) stated that the largest roosts were in southern Indiana, central Illinois, and along the Missouri River to the west. His map showed no roosts in the southern half of Illinois, and even Black (1941) generally found fewer and smaller roosts in the south away from the St. Louis area.

In efforts to reduce crow numbers during the 1920 s and 1930 s, many states sponsored shooting and roost bombing campaigns. The Department of Conservation estimated the kill from shooting in Illinois to be about 300,000 crows in 6 years $(1934-1939$ inclusive) and about 630,000 from dynamite bombs. Black (1941) estimated the kill-from his own counts of dead crows after bombings - to be about half the Department's estimate.

\section{Winter}

Probably every township in Illinois has crows sometime during the winter, yet definite records are lacking for many (Fig. 13). Even in Chicago, the crow was considered to be one of the most common winter birds (Sanborn 1922). We estimated the state population of crows to have been about 4.8 million in January 1907 and 1.4 million in January 1957 (R.R. Graber and J.W. Graber 1963), with more of the population in both cases in the central region of the state than in the north or south. By comparison, June numbers were about 1.2 million in 1909 and about 300,000 in 1957 and 1958. The change, both winter and summer, was on the order of $-4 \times$. Since many of the winter crows in Illinois come from the northeast, the data suggest that the decline was widespread in other states. Black $(1939,1941)$ estimated the Illinois winter population to be over 1 million crows in about 100 roosts. His roost surveys, however, were made in the 1930s, and even if they were reasonably complete, much of the decline may already have occurred by that date. A roost study comparable to Black's would serve to indicate the current winter crow population and to tell us whether or not it has stabilized. Because of the extensive area, the study would probably need to be cooperative, involving many observers. Bottomland forest appears to be the favorite woody habitat of crows in winter (Table 8 ). 'They occur with remarkably high densities ( $5 / 40 \mathrm{ha}$ ) in nearly all open field habitats when large sample areas $(100+\mathrm{ha})$ are censused. For a bird as rangy as the crow, however, census areas should perhaps be 1 or more $\mathrm{km}^{2}$.

Black (1941) observed large variations in age and sex ratios of crows from different roosts. In general, 
however, stratification of the sexes (ages) followed latitude in winter, with immature females-but not males-increasing to the south. In fact, relatively more immature males were found in the north. When we examined age ratios of crows in Black's data for December-early January (2,902 specimens aged), we found the overall ratio to be 59 adults to 41 immatures. By comparison, for late January-February specimens (939 aged), the ratio was 63 adults to 37 immatures. The reduction of immatures could be construed as differential winter mortality, but latitude data do not fit that interpretation. The ratio of adult to immature birds in late winter was 60 to 40 in the north, 61 to 39 in the central region, and 68 to 32 in the south. The reduction of immatures in the south compared

\section{American Crow} Winter Records Dec. 15-Feb. 1

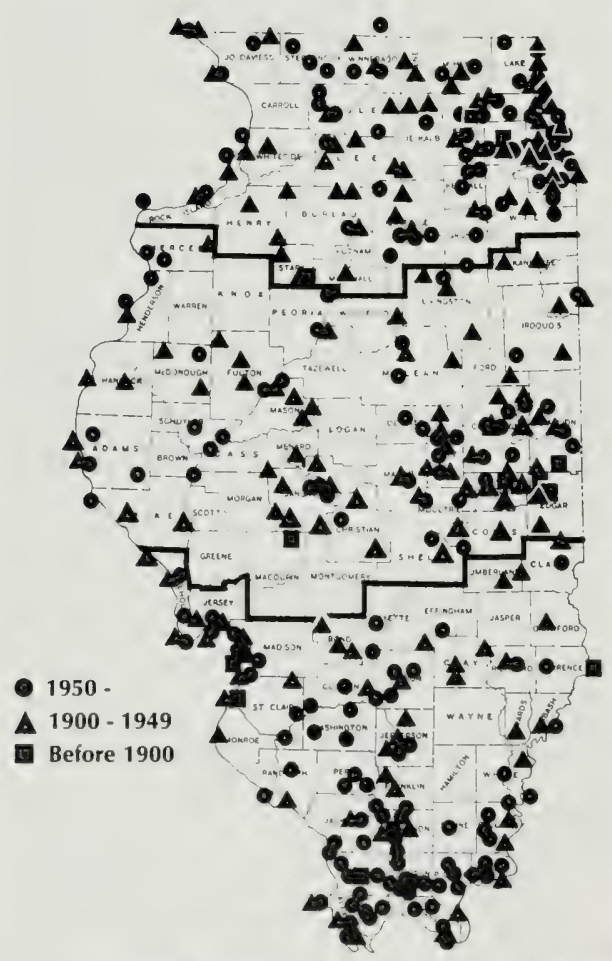

Fig. 13.-Winter records of the American crow in Illinois. Heavy horizontal lines indicate the three regions of the state (north, central, and south) referred to in the text. to numbers in the north and central may have more to do with early migration from the south than with mortality. Black (1939) observed that at central Illinois roosts there was a steady increase of adult females and immatures during February (the beginning of spring migration?).

Christmas bird counts show the same regional pattern of crow numbers as our censuses, i.e., highest numbers in the central region. The average number seen during the 44-year period (1940-1983) in which counts have had reasonably good coverage was 7.8 crows per party hour in the north, 10.3 in the central region, and 7.9 in the south, with an overall state average of 8.6. The data do not include counts made at crow roosts. The generally higher counts in central Illinois may be related to the availability of food. Especially before 1960, mechanical corn pickers left much grain in the fields, but even later Warner's (1982) data on cornfields in east-central Illinois revealed a residue of waste grain in untilled cornfields of $420 \mathrm{~kg} / \mathrm{ha}$; even plowed fields had $10 \mathrm{~kg} / \mathrm{ha}$. Northern fields might be expected to offer as much food, but the area also offers a less favorable climate. Southern areas, on the other hand, provide a more favorable climate than the central area but less grain. Winter counts along major rivers (Mississippi, Ohio, Wabash) were consistently higher than those away from rivers. The average count on rivers was 12.4 crows per party hour; away from rivers the count was 2.3 .

\section{Food}

As with virtually all aspects of crow biology in IIlinois, Black's (1941) data on food are particularly good because of their quantitative nature. From an examination of 1,214 regurgitated pellets and 718 stomachs of winter birds nearly all from central 11 linois, he found corn to be overwhelmingly the principal winter food-94.7 percent of the pellet contents and 93.1 percent of the stomach contents. Other vegetable foods were seeds of smooth sumac, poison ivy, hemp, hackberry, linden, and giant ragweed and tubers of a sedge, all in measurable amounts -0.1 to 3.5 percent. The preponderance of bottomland plants is apparent. Seeds of 21 other plants were present in quantities of less than 0.1 percent. Grit made up 20.5 percent of the volume of stomach and pellet contents; mice and shrews amounted to 1.4 to 3.0 percent. More Peromyscus (93 in pellets, 31 in stomachs) than Microtus $(73,16)$ or shrews $(12,12)$ were taken. Insect fragments constituted 0.3 to 0.4 percent and crayfish and snailshells 0.2 percent or less. Eighteen stomachs of crows from the "warmer months" also contained mainly corn (62 percent of the food). Insects were more important (12.6 percent) at that season than in winter. The stomachs of six nestlings had 58.3 percent insects and 6.8 percent corn. 
In a study that included specimens from each state (total, 2,118; Illinois, 24), Kalmbach (1918) found vegetable food to be most important for the crow-71.9 percent on an annual basis and especially high in fall and winter. Corn and wild fruit were the most important items, with corn making up 50-60 percent of the diet, October-January inclusive. The wild fruits included acorns, sumac, and poison ivy. A sample of nine pellets from St. Louis had an average of 36 poison ivy seeds per pellet along with seeds of sumac, grape, dogwood, hackberry, wild bean (Strophostyles), and buckthorn (Bumelia).

Kalmbach's (1918) study showed that animals made up 28.1 percent of the crow's food on an annual basis (highest in May, 52.4\%; lowest in February, $11.0 \%)$. Animal content was consistently low (10-18\%) in late fall and winter. Insect food was highest in MayAugust inclusive (e.g., May, 39.8\%; July, 33.8\%). Beetles, especially May beetles (Phyllophaga sp.), were the most important insect ( $21 \%$ of the food). In a sample of 197 adult crows, Kalmbach detected Phyllophaga in the stomachs of 156; nestling crows also had many Phyllophaga grubs in their stomachs. Forbes (1908:156-157) described crows tearing up the sod of hayfields and lawns in their search for grubs. In central Illinois large flocks of crows followed the plow to get Phyllophaga grubs (Bent 1946). Parmalee (1949) noted that grubs became increasingly important in the diet as nestlings got older. Ground beetles (including Calosoma) were 1.56 percent of the animal diet of adults and an even higher percent of the animal diet of nestlings. A crow in Illinois in November had in its stomach 80 larvae of the broad ground beetle (Pasimachus sp.). Orthoptera made up 7.3 percent of the food of adult crows; Lepidoptera (especially caterpillars) constituted 1.6 percent of the adult food and 5.3 percent of the food for nestlings, with noctuids most prevalent. Hemiptera, Hymenoptera, and Diptera were all relatively unimportant in the crow's diet. Spiders-mostly wolf spiders-made up less than 1 percent of the adult crow's food but constituted a large part of the nestling's diet.

Kalmbach (1918) referred to I. Hess's account of a crow attacking a prairie-chicken nest but noted that fish crows eat more bird eggs than do American crows. A number of observers have seen crows eating aquatic organisms. Widmann (1888) and Musselman (1913, 1934-1935) reported crows scavenging along the Mississippi and Sangamon rivers, eating dead shad and carp (see also Southern 1966). Hall (1930) saw large flocks of crows feeding on fish frozen in shallow lakes, and B.T. Gault (unpublished 1918) saw them hunting crayfish near Glen Ellyn in late October. During an eruption of caterpillars in Pope County, April-May 1980-1981, crows fed on the larvae in the very top of the forest canopy.
Crows also eat road kills and other carrion, notably rabbits (Swink 1976; Crook 1936), pheasants, chickens, cats, dogs, opossums, skunks (Crook 1936). Other carrion eaten by crows include a flicker (Colaptes auratus), a horse (Anonymous 1882), and a snake (S. Jones 1934), to mention only those for which records exist. Frink (1970) observed an episode of food pirat. ing that began with a common merganser that caught a fish, which was taken from it by a ring-billed gull, then from the gull by a crow, which ate the prize. George and Kimmel (1977) observed crows cache food. The authors released 100 white laboratory mice on an open grassy knoll; crows killed and cached 79 of them in $127 \mathrm{~min}$. G.C. Sanderson (unpublished) witnessed several attacks by a crow on a cottontail in January 1958. Crows are not often reported at feeders, but Roberts (1922) saw one eat at his suet feeder in Lake Forest a few times in winter. In Pope County a pair of crows brought three recently fledged young to grain (mostly corn) at a ground feeding area within $15 \mathrm{~m}$ of our house, where all fed in early morning and late afternoon in June 1984.

\section{Mortality Notes}

Parmalee (1957) found the remains of a crow among several hundred items in kitchen middens (A.D. 1200-1550) at Cahokia Mounds. At Eldred, Parmalee et al. (1972) recorded the remains of 4 crows among the remains of 976 birds representing the period A.D. 450-750. Whether these were ceremonial or food items cannot be determined. Indians were not serious predators of the crow, with the possible exception of eggs. Strode (1889b) and a companion collected 50 crow eggs in a day at a time when it was legal to do so.

The automobile has not been a serious problem for the crow. Blocher (1936) found 5 crows believed to be immatures dead on the road during one year in which he drove 24,000 miles. Starrett (1938) found 3 crows among 607 road-killed birds within 80 miles of Peoria in 1937.

Cahn and Kemp (1930) recorded the barred owl as a predator of the crow. At one nest of horned owls in Champaign County, crows appeared to be the principal food.

Historically, the shooting and bombing campaigns of the 1930s may have been the most effective cause of mortality among crows. Black (1941) lists a death rate of about 100,000 birds a year out of a winter population at the roosts of about 1 million. Many of these birds may have represented northern breeding populations. Whether the bombings had a prolonged effect on the Illinois population of crows is uncertain; however, Black believed the shooting campaign was more important. Crow shooting was (and is) avidly 
pursued by some hunters. Hess (1910) mentioned a one-day kill by two men of 197 crows. To our knowledge, no measurement of the kill has been made since Black's (1941).

Kalmbach (1918) believed that disease, particularly epidemics of ulcerative keratitis ("roup"), was the most important mortality factor among crows, although the disease was unknown in Illinois at that time. We are not certain of the disease to which he was referringpossibly it was Candidiasis, a disease that is believed to be relatively rare among wild birds at the present time (Cooper and Eley 1979). Two parasites have been recovered from Illinois crows-Porrocaecum nematodes contracted by a young captive fed earthworms (Parmalee 1952) and Stephanoprora polycestus in captive crows fed fish (Beaver 1936) - but the effect of either on the crow population is unknown.

Kendeigh (1982) observed that the disappearance of nesting crows coincided with the appearance of great horned owls in Trelease Woods. At Kewanee long-eared owls regularly made use of unoccupied crow nests (Murchison 1892), but this behavior was probably not detrimental to the crows. Bodensten (1932b) observed that a crow whose mate had been killed did not return to its nest.

Harassment of other species of birds by crows is commonplace, with observations on horned owls (Silloway 1894; Franks and Warnock 1969), barred owls (Craigmile 1931), turkey vultures, red-tailed and redshouldered hawks (B.T. Gault, unpublished 1895, 1917; Labahn 1932), and marsh hawks. Conversely, crows have been harassed by "blackbirds," grackles, kingbirds, and probably many others (Silloway 1906b; Gault 1917; Ekblaw 1919). Taber (1927) described the behavior of trapped crows in pens.

\section{Specimen Data}

Black (1941) examined 220 crow specimens to determine longevity of the bursa Fabricii. All specimens with the bursa also had immature characters of plumage: worn, blunt, brownish rectrices and white (under) rachis of remiges. Some specimens taken in mid-February still had prominent bursae $(75 \%$ of the immatures in mid-February versus $97 \%$ in midDecember), but Black considered the bursa an unreliable indicator of age after 8-9 months.

Winter weights of 248 adult male Illinois crows averaged $538.1 \mathrm{~g}$; those of 160 immature males averaged $511.4 \mathrm{~g}$; those of 245 adult females, $473.8 \mathrm{~g}$; and those of 203 immature females, $458.9 \mathrm{~g}$ (Black 1941). Winter weights decreased with latitude. In the north, the weight of adult males averaged $554 \mathrm{~g}$ and that of adult females, $489 \mathrm{~g}$; in the central region, the weight of adult males averaged $537 \mathrm{~g}$ and that of adult females, $474 \mathrm{~g}$; in the south, the weight of adult males averaged $531 \mathrm{~g}$ and that of adult females, $467 \mathrm{~g}$.

Weights of crows during the breeding season were substantially lower than winter weights. Average May weights for Lee County specimens were $533 \mathrm{~g}$ for ten adult males, $498 \mathrm{~g}$ for five yearling males, $458 \mathrm{~g}$ for thirteen adult females, and $437 \mathrm{~g}$ for four yearling females. Crows appear to have moderate or little fat even in winter.

\section{FISH CROW (Corvus ossifragus)}

\section{(Fig. 14)}

Fish Crows, if silent-as they might tend to be in winter-could easily be overlooked or assumed to be American crows. This oversight may explain the general absence of winter records in Illinois; however, Baird et al. (1874) stated that fish crows are migratory and retire to southern coastal areas in winter, and our Figure 15 represents that status. Students should nevertheless continue to look for this species in winter in order to determine whether the entire Illinois population migrates and if it migrates every year. The presence of fish crows in southeastern Missouri in late December (Hamilton 1968; Anderson 1971) suggests the possibility that the species winters in or close to Illinois, although these records could also be interpreted as late migration.

Fish crows increase or at least become more conspicuous in Illinois in March and April (Fig, 16). An isolated record for the St. Louis area on 1 February (Wilson 1982) is the earliest report for the region. The migration-presumably diurnal-has not been

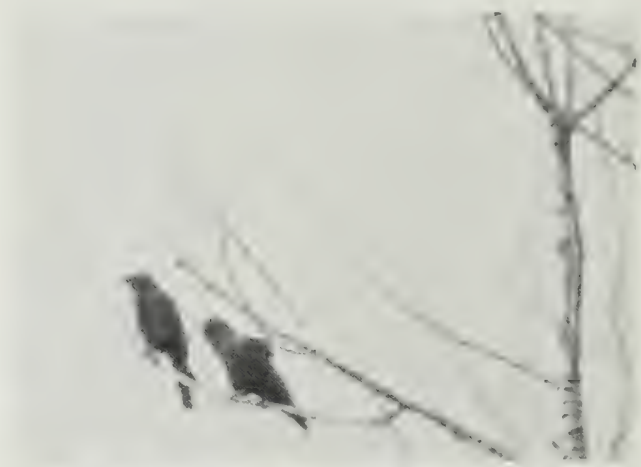

Fig. 14.-Fish crows near the Big Muddy River, north of Wolf Lake, Illinois, 18 August 1986. 
observed in Illinois. An afternoon assemblage of about 100 fish crows near Tamms on 12 April was a sudden increase in our counts that almost certainly represented migration. Anderson (1971) reported a migration "pulse" of 34 in southeastern Missouri, and Kleen and Bush (1972) reported flocks of over 20 on 6 and 15 May in southern Illinois.

The history of the fish crow within or near the present range of the species in Illinois (Fig. 17) may date back to 8000 B.C.-A.D. 1500 and A.D. 200-100 at Indian archeological sites (Parmalee 1967, 1968); however, these records may refer to Indian trade items from the coast rather than to wild free birds in Illinois. That there has not been a continuous presence of fish crows in Illinois for hundreds of years is also indicated by Audubon's [1840-1844] (1967) remark that the range of the fish crow did not extend further north than 500 miles up the Mississippi River (i.e., just short of Illinois in a straight line). Other historical observations, however, do not necessarily agree. Johnston (1961), for example, noted that the fish crow had reached Memphis only in the last decade (i.e., 1950 s); Easterla (1965) contended that the fish crow first reached Missouri in 1964. The progression of

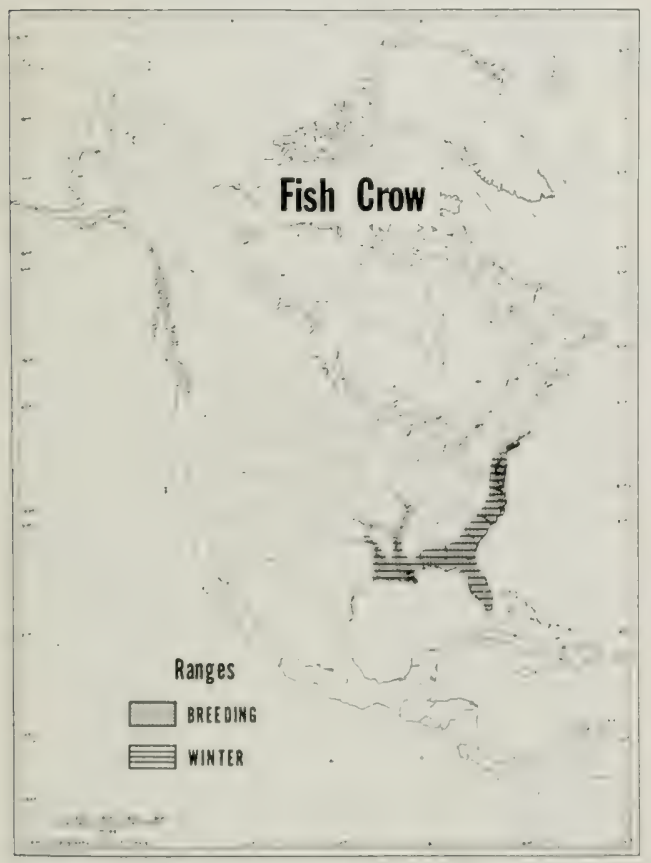

Fig. 15. - General distribution of the fish crow. years seems reasonable for the possible advance of the fish crow northward. Neither Ridgway [1889] (1913) on the east side of Illinois nor Widmann (1907) on the west found fish crows-good evidence that the fish crow had not reached their areas of study in the nineteenth century. Over the centuries fish crows may have reached Illinois many times, but the current population is probably represented by the above history.

The range now extends along the Mississippi River to north of St. Louis (Alton dam) and along the Ohio to Pope County and possibly to Gallatin County (Kleen 1984). Although the fish crow is not yet known on the Cache and Kaskaskia rivers, its appearance is expected.

Anderson (1966) found evidence of breeding (but no nest) in Illinois southeast of St. Louis, and Kleen (1983-1984) reported a pair with fledged young at Granite City on 4 July. As far as we know, however, no nest has been found in Illinois.

Fish crows are usually seen in the floodplains of major rivers, both in open fields and woodlands, i.e., habitat not notably different from that of the American crow in extreme southern Illinois. Though the two species usually remain separated, we have seen flocks that included both species mobbing raptors several times in Union, Jackson, and Pope counties.

Fish crows are reputed to frequent heron colonies, where they pilfer eggs (Bent 1946). In our survey of herons (J.W. Graber et al. 1978), we generally avoided colonies during the incubation season and saw fish crows only at a colony of little blue herons at Billings Island in July, when the heron young were well grown. The habitat there was young willow thicket that dif-

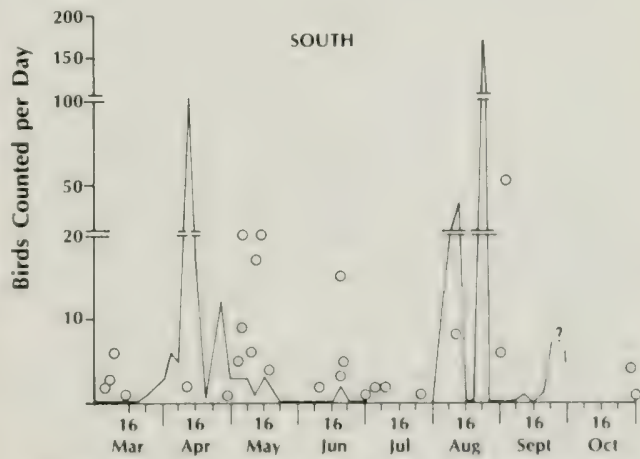

Fig. 16.-Migration seasons of the fish crow in southern Illinois. Spring and fall lines show the highest daily count of each 4 days (1967-1970). Circles represent counts made in other years or by other observers. 
fered from the more mature forests in which we found most heron colonies. In areas where fish crows occur, we have censused hundreds of acres of mature bottomland forest without detecting the species in that habitat. In southern Pope County, where cultivated fields were interspersed with swamps, we observed (May-July 1986) that fish crows were persistently associated with the deeper lagoons and their treeslarge specimens of bald cypress (Taxodium distichum), pecan (Carya illinoensis), green ash (Fraxinus pennsylvanica), and silver maple (Acer saccharinum). Though we did not witness territorial behavior, two to four apparently adult fish crows daily frequented an area with a crow nest in this habitat. The nest, located 58 $\mathrm{ft}$ high $(17.7 \mathrm{~m})$ in a green ash, produced no young and was not attended by a bird while we observed it. Fish crows were extremely shy in this "nesting area"

\section{Fish Crow}

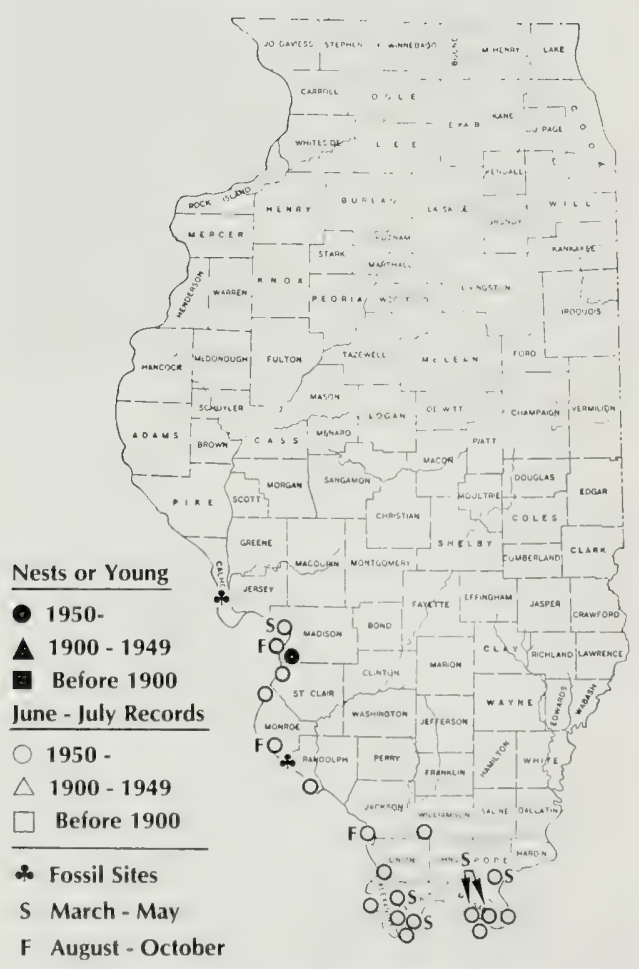

Fig. 17.-Distribution of fish crow records in Illinois. all summer. The common call by fish crows in this area was a double-noted "Kut-Kar" or "Kar-Kar" repeated over and over.

Jared Garver found fish crows roosting in a conifer plantation high on Bald Knob, Union County, 21 April 1986.

Fish crows in Union County were molting extensively on 21 August, generally later than American crows in the area. There are many Illinois records for the fish crow in August-September, with counts as high as 39 . The migration has not been observed, but numbers appear to diminish after September (Fig. 16). The last in fall were seen on 29 and 31 October (Robbins 1979; Kleen 1981c). To what extent the disappearance is related to reduction in calling by fish crows rather than to emigration cannot be judged, and this species obviously needs special study in Illinois. Because fish crows are a relatively distinctive species, much can be learned by careful observation without the large scale collecting of specimens. Most observers are aware of the similarity between the common "Kar" or "Kor" call of the fish crow and that of newly fledged American crows, but even those calls are distinguishable.

\section{COMMON RAVEN (Corvus corax)}

Raven remains have been found in Indian burials and middens dating from A.D. $900-1800$ in all three regions of the state (Fig. 18; Parmalee 1958, 1964, 1967; Parmalee and Bogan 1980). These specimens may have belonged to the local population, as ravens were thought to be not uncommon before the 1870 s (Kennicott 1853-1854; Ridgway 1873; Nelson 1877). Kennicott stated that ravens were known to nest in Cook County, and Ridgway [1889] (1913) stated that one or two pairs were present in summer in large bottomland woods on Big Creek west of Olney up to 1871. One was killed in early July 1875 in this area (Nelson 1877). That year ravens were also present along Lake Michigan, where a specimen was collected 15 October (Ford 1956). Several were seen near Waukegan on 1 November feeding on dead fish, and small flocks wintered (Ridgway [1889] (1913). A female raven was collected 23 October 1892 at Meredosia (Morgan County), where it was feeding on carrion and where it had been for at least a week (Woodruff 1896, 1907). One was killed at Calumet Heights in fall 1897 (Anonymous 1897; Woodruff 1907). Widmann (1907) referred to specimens collected in Hancock County many years prior to 1907 . A specimen from Fayette County was collected 
10 January 1901 (Illinois State Museum Collection). There were sight records of ravens in Lake County in spring 1908 and 1926 (Cory 1909; Coale 1912; Grasett 1926) and in Cook County, October 1953 (Bohlen 1978). A captive raven that had apparently escaped was present in Peoria throughout 1969 (Princen 1970). A recent report of a raven was of one seen on 17 December 1983 at Dubuque, lowa. As long as healthy populations of ravens exist in the north, infrequent sightings in Illinois will probably continue to be made in fall or winter.

Illinois specimens have been identified as C. c. principalis (Woodruff 1896). Ridgway (1904) believed the breeding population in southern Illinois was $C$. $c$. sinuatus.

\section{Common Raven Records}

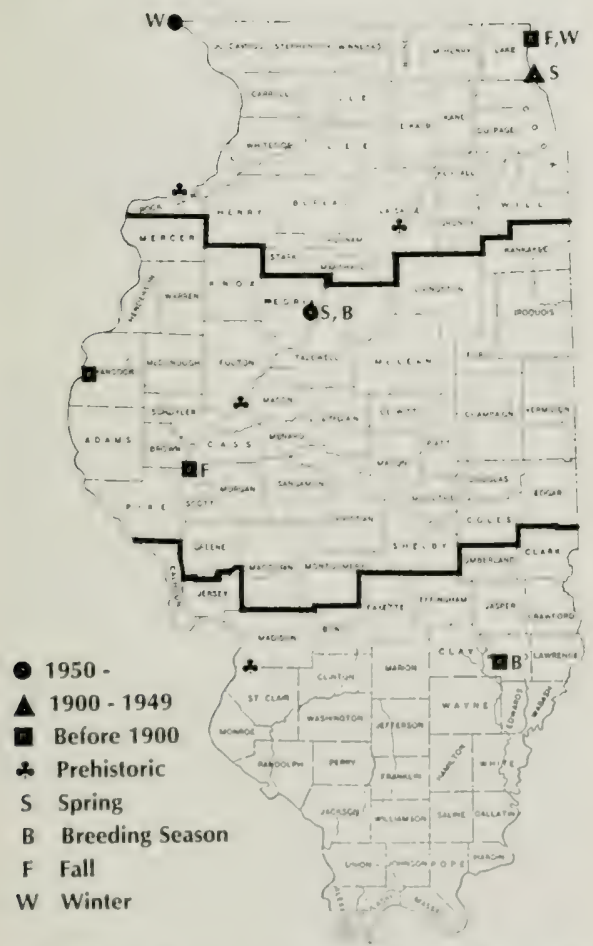

Fig. 18.-Distribution of records of the common raven in Ilinois. Heavy horizontal lines indicate the three regions of the state (north, central, and south) referred to in the text.

\section{LITERATURE CITED}

Allen, J.A. 1868. Notes on birds observed in western lowa in the months of July, August, and September; also on birds observed in northern Illinois in May and June, and at Kichmond, Wayne Co., Indiana, between June third and tenth. Boston Society of Natural History Memoirs 1:488-526.

Anderson, R. 1966. Summer survey: June I to August 15. Bluebird 33(2):11-12, 24.

1971. Bird survey. Bluebird 38(1):2-4

Anonymous. 1882. Albinos. Ornithologist and Oologist 7(15):115.

1897. From the sandhills. Forest and Stream 49:407.

1917. Spring census and migration record: Urbana. Audubon Bulletin, spring:53-54.

1936. Returns. U.S. Department of Agriculture, Bureau of Biological Survey, Bird Banding Notes 2(14):244-245.

Audubon, J.J. 1967. The birds of America. Vol. 4. Dover Publica tions, Inc., New York. 321 p. [First published 1840-1844.]

Baird, S.F., T.M. Brewer, and R. Ridgway. 1874. A history of North American birds. Land birds. Vol. 1. Little, Brown, and Company, Boston. 596 p.

Ballou, W.H. 1878. Bird arrivals. Ornithologist and Oologist 4(1):6. Barnes, R.M. 1890. List of birds breeding in Marshall County, III Ornithologist and Oologist 15(8):113-116.

. 1914. Large sets (editor's note), Oologist 31(5):80.

1934a. Dynamiting the crow. Oologist 51(2):23.

1934b. War on the crow. Oologist 51(2):24-25.

Bartel, K.E. 1945. Returns from nestlings banded. Inland Bird Banding News 17(5):31.

1958. [untitled]. Inland Bird Banding News 30(4):29.

1962. Banded returns. Inland Bird Banding News 34(4): $51-52$

1966. After 32 years of banding. Inland Bird Banding Association News 38(4):66-69.

- 1967. Longevity data from thirty-three years of banding. Inland Bird Banding Association News 39(5): 123.

_ 1976. My 42 years of bird banding. Inland Bird Banding New's 48(2):55-65.

_ 1977. 1976-77 cold winter excellent for banding winter birds. Inland Bird Banding News 49(3): 106-108.

E. Jurica, V. Laketek, and J. Spoden. 1963. Banding returns for 1962. Inland Bird Banding New's 35(3):58 and 60 .

Beall, L.F. 1908. A southern Illinois lunch counter. Bird-Lore 10(6):255-257.

Beaver, P. 1936. Notes on Stephanoprora polycestus (Diet2) from the American crow. Illinois State Academy of Science Transactions 29(2):247-250.

Beecher, W.J. 1942. Nesting birds and the vegetation substrate Chicago Ornithological Society. $69 \mathrm{p}$

Beltrose, F., Jr. 1934-1935. Winter birds around a feeding station. Auduton Bulletin 24-25:39-42.

Bellrose, F.C. 1972. Possible steps in the evolutionary developmen of bird navigation. Pages 223-257 in S. K. Galler, K. Schmidt. Kocnig, G.J. Jacobs, and R.E. Belleville, cds. Animalorientation and navigation. National Acronautics and Space Administra. tion. NASA SP'-262.

Bent, A.C. 1946. Life histories of North American jays, crows, and titmice. U.S. National Museum Bulletin 191. $495 \mathrm{p}$.

Birkenholy, D.F. 1975. The summer birds of Coose Lake Prairic Nature Preserve, 1970-1973. Chicago Academy of Sciences Natural History Miscellanca 193. 11 p.

- 1977. Forrieth breeding bird census: 40. Oak-hickory-maple forest. American Birds 31(1):43. 
1978. Forty-first breeding bird census: 38. Oak-hickorymaple forest. American Birds 32(1):66.

1979. Forty-second breeding bird census: 34 . Oak-hickorymaple forest. American Birds 33(1):65.

- 1980. Forty-third breeding bird census: 33. Oak-hickorymaple forest. American Birds 34(1):52.

1981. Forty-fourth breeding bird census: 40. Oak-hickorymaple forest. American Birds 35(1):59-60.

Bjorklund, R.G., and J.R. Deters. 1972. An annotated checklist of the birds of Mason State Forest. Peoria Academy of Science Proceedings 5:20-24.

Black, C.T. 1939. Proceedings of the Wilson Ornithological Club, program session 16, Illinois crow roosts. Wilson Bulletin $51(1): 54-55$.

1941. Ecological and economic relations of the crow, with special reference to Illinois. Ph.D. Thesis. University of Illinois. 186 p. + appendices.

Blocher, A. 1933. Depression. Oologist 50(4):57-58.

1936. Fatalities. Oologist 53(2):19-22.

Bock, C.E., and L.W. Lepthien. 1976. Changing winter distribution and abundance of the blue jay, 1962-1971. American Midland Naturalist 96(1):232-236.

Bodensten, A.J. 1932a. Set of seven blue jay's eggs. Oologist $49(4): 45-46$

1932b. A sad sight. Oologist 49(8):96.

1934. Items from Congress Park. Oologist 51(4):48.

Bohlen, H.D. 1978. An annotated check-list of the birds of Illinois. Illinois State Museum Popular Science Series 9. 154 p.

Braband, L. 1976. Twenty-ninth winter bird-population study: 26 Upland oak-maple forest. American Birds 30(6): 1049-1050.

Brewer, R. 1958. Breeding-bird populations of strip-mined land in Perry County, Illinois. Ecology 39(3):543-545.

Brintnall, A.W. 1918. Notes from field and study: our summer boarders. Bird-Lore 20(6):421-422.

Brodkorb, P. 1928. The season: Chicago region. Bird-Lore $30(1): 17$

1930. Notes from Illinois. Auk 47(1):97-98.

Brown, L.G., and F.C. Bellrose, Jr. 1943. Use of nesting boxes for wood ducks by other wildlife. Journal of Wildlife Management 7(3):298-306.

Brown, M.K. 1975. The Zimmerman Site: further excavations at the Grand Village of Kaskaskia. Illinois State Museum Reports of Investigations $32.124 \mathrm{p}$

Buck, D. 1981. Field notes-spring 1980. Indiana Audubon Quarterly 59(4): 123-143.

Burns, F.L. 1895. The American crow (Corvus americanus). Wilson Bulletin 7(5): 1-41.

Butler, A.W. 1897. Some Indiana crow roosts. Indiana Academy of Science Proceedings 1897:175-178.

Cahn, A.R., and A.S. Hyde. 1929. Easter birds of Little Egypt Wilson Bulletin 41(1):31-38.

_..._- and J.T. Kemp. 1930. On the food of certain owls in eastcentral Illinois. Auk 47(3):323-328.

Calef, R.T. 1953a. Ecological analysis of the flora and vertebrate fauna of Funks Forest Natural Area, McLean County, Illinois M.S. Thesis. University of Illinois. $85 \mathrm{p}$.

- 1953b. Avian populations of the Funk Forest Natural Area in McLean County, Illinois. Illinois State Academy of Science Transactions 46:240-257.

Chaniot, G., and R. Kirby. 1955a. Winter bird-population study 27. Grazed stream bottomland. Audubon Field Notes 9(3):303.

- and $\longrightarrow$ 1955b. Nineteenth breeding-bird census: 4. Grazed stream bottomland. Audubon Field Notes 9(6):413.

_ and 1956. Winter bird-population study: 23. Grazed stream bottomland. Audubon Field Notes 10(3):296-297.

Chase, V.P. 1899. A bloodthirsty blue jay. Wilson Bulletin 11 (4):5556
Cleland, Mrs. 1922. Belvidere. Audubon Bulletin, fall:32-33.

Clemans, R.J. 1974. The bioenergetics of the blue jay in centra! Illinois. Condor 76(3):358-360.

Coale, H.K. 1911. Clarke's nutcracker in Illinois. Auk 28(2):266. - 1912. Birds of Lake County, Illinois. Pages 353-370 in J.J.

Halsey, ed. A History of Lake County, Illinois. Roy S. Bates, Chicago.

1919. Magpie (Pica pica hudsonia) in northeastern Illinois. Auk 36(1):113-114.

Comfort, J.E. 1945. Webster Groves Notes. Bluebird 12(8):46-47. . 1955. Birds of the St. Louis area. Bluebird 22(6):n.p.

Cone, B. 1956. Half a ton of cheese. Audubon Bulletin 97:4-5.

Cooke, M.T. 1937. Some longevity records of wild birds. BirdBanding 8(2):52-65.

1942. Returns from banded birds: some longevity records of wild birds. Bird-Banding 13(3): 110-119. 18.

Cooke, W.W. 1883. Mississippi valley migration. Ornithologist and Oologist 8(4):25-27.

- 1885. Mississippi valley migration-spring of 1883 . Ornithologist and Oologist 10(12):177-178.

. 1888. Report on bird migration in the Mississippi valley in the years 1884 and 1885. U.S. Department of Agriculture, Division of Economic Ornithology, Bulletin 2. 313 p.

_. 1916. Second annual report of bird counts in the United States, with discussion of results. U.S. Department of Agriculture Bulletin 396. $20 \mathrm{p}$.

Cooper, J.E., and J.T. Eley, eds. 1979. First aid and care of wild birds. David and Charles, Inc., North Pomfret, Vt. 288 p.

Cory, C.B. 1909. The birds of Illinois and Wisconsin. Field Museum of Natural History Publication 131, Zoological Series 9. 764 p.

Craigmile, E.A. 1931. Notes from River Forest. Chicago Academy of Science Program of Activities 2(2):n.p.

1937. A bird bath. Audubon Bulletin 27:34-35.

Crook, C. 1936. A winter food supply for the crow. Auk 53(3):337338.

Deane, R. 1899. Habits of the blue jay. Auk 16(2):182.

De Vos, A. 1964. Range changes of birds in the Great Lakes region. American Midland Naturalist 71(2):489-502

Dickinson, J.E. 1884. Blue jay. Ornithologist and Oologist 9(2):24.

Dillon, S. T. 1968. A bird census on a restricted site in northeastern Illinois. Audubon Bulletin 146:16-20.

Downing, P.E. 1941. About starlings and other birds. Inland Bird Banding News 13(1):6.

1949. Bird banding results. Audubon Bulletin 71:15-16. 1952. Rare jay in Highland Park. Audubon Bulletin 83:3.

Du Mont, P.A. 1935. The 1934-35 magpie invasion into lowa. lowa Bird Life 5(3):46.

, and E.T. Smith. 1946. Audubon field notes: middle-western prairie region. Audubon Magazine 48(5): 123-124 (Section 2).

Dunn, J.O. 1895. Notes on some birds of northeastern Illinois. Auk 12(4):393-395.

Easterla, D.A. 1965. Range extension of the fish crow in Missouri. Wilson Bulletin 77(3):297-298.

Ebinger, C.E. 1931. Keokuk, lowa. Bird-Lore 33(1):65.

Editor. 1955. Briefs. Bluebird 22(3):n.p.

E.E. 1885. English sparrows: what is to be done with the little tyrants? The Young Oologist 1(11):146.

Eifrig, C.W.G. 1915. An unintentional bird preserve. Wilson Bulletin $27(4): 458-460$.

1919. Notes on birds of the Chicago area and its immediate vicinity. Auk 36(4):513-524.

Ekblaw, G.E., and E.L. Ekblaw. 1916. Spring census and migration records for 1916: Rantoul. Audubon Bultetin, spring:43-44.

Ekblaw, W.E. 1919. Birds from a sick man's window. Wilson Bulletin $31(3): 91-97$. 
Etter, A.G. 1963. Wildwood: a study in historical ecology. P'art 2. Bluebird $30(1): 10-27$.

Evermann, B.W. 1920. Notes on the birds of Carroll, Monroe, and Vigo counties, Indiana. Indiana Academy of Science Proceedings 1920:315-401.

Fawks, E. 1937. Bird-Lore's first breeding-bird census; secondgrowth hardwood. Bird-Lore 39(5):380.

1938. Bird-Lore's second breeding-bird census: secondgroweh hardwood. Bird-Lore $40(5): 359$.

- 1966. Field notes-June 1966. Audubon Bulletin 138:6-8.

1967. Field notes. Audubon Bulletin 143:17-21.

1968. Field notes. Audubon Bulletin 146:27-29.

Fawver, B.J. 1947. Bird population of an Illinois floodplain forest. Illinois Academy of Science Transactions 40:178-189.

Finley, C.IW. 1917. Birds of the campus. Normal School Quarterly $30.28 \mathrm{p}$.

Flentge, L.G. 1938. 1937 banding activities. Inland Bird Banding News 10(1):5.

Flint, W.P. 1934-1935. The automobile and wild life: animals killed on a 25-mile stretch of Illinois highway from 1930 to 1933. Illinois Academy of Science Transactions 27(2):150-153.

Forbes, S.A. 1878. The food of birds. Illinois Horticultural Society Transactions 23:140-145.

1881. The ornithological balance-wheel. Illinois Horticultural Society Transactions 26:120-131.

- 1908. Twenty-fourth report of the state entomologist on the noxious and beneficial insects of the state of 11 linois. $168 \mathrm{p}$.

Ford, E.R. 1956. Birds of the Chicago region. Chicago Academy of Sciences Special Publication 12. 117 p.

Fowells, H.A. 1965. Silvics of forest trees of the United States. U.S Department of Agriculture, Forest Service, Agriculture Handbook $271.762 \mathrm{p}$.

Franks, E.C., and W. Martin. 1967. Thirty-first breeding-bird census: 6. Upland oak-hickory forest. Audubon Field Notes $2 I(6): 615$.

—, and J.E. Warnock. 1969. General notes: great horned owl nesting in a populated area. Wilson Bulietin 81(3):332-333.

Friedmann, H. 1963. Host relations of the parasitic cowbirds. U.S. National Museum Bulletin 233. 276 p.

Frink, J., Mr. and Mrs. 1970. The third handed fish. Audubon Bulletin 154:15.

Gammell, A.E. 1928. A come back. Oologist 45(9):130-131.

Gates, F.C. 1911. Summer bird life in the vicinity of Havana, 1llinois, in its relation to the prominent plant associations. Wilson Butletin 23(1):1-27.

Gault, B.T. 1901. Birds and seasons: February and March bird-life at Glen Ellyn (near Chicago), Illinois. Bird-Lore 3(1):26-27.

. 1917. Spring census and migration record: Glen Ellyn. Audubon Bulletin, spring:46-47.

George, W.G., and T. Kimmel. 1977. A slaughter of mice by common crows. Auk 94(4):782-783.

Goelitz, W.A. 1916. "Two trials. Oologist 33(8): 153.

Graber, J.W., and R.R. Graber. 1979. Severe winter weather and bird populations in southern Illinois. Wilson Bulletin 91(1):88103.

- 1 and 1983. Expectable decline of forest bird populations in severe and mild winters. Wilson Bulletin 95(4):682690.

, and E.L. Kirk. 1977. Illinois birds: Picidac. Illinois Natural History Survey Biological Notes 102. 73 p.

- - and 1 1978. Illinois birds: Ciconiiformes. IIlinois Natural History Survey Biological Notes 109.80 p.

- 1 , and 1983. Illinois birds: wood warblers. Illinois Natural History Survey Biological Notes 118.144 p.

_ and P.M. Powers. 1981. Dwarf sumac as winter bird fool. American Midland Naturalist 105(2):410-412.
Graber, R.R. 1962. Regional reports, nesting season June I to du. gust 15, 1962: middlewestern prairie region. Audubon Field Notes $16(5): 478-480$.

lations in Illinois, 1906-1909 and 1956-1958. Illinois Natural History Survey Bulletin 28(3):38:3-528.

- , and - 1979. Red-heads and pin oaks. Illinois Audubon Bulletin 188:35-38.

Grasett, F.G. 1926. General notes: notes on some rare birds of northeastern Illinois. Auk 43(4):556.

Greene, S.H. 1960. Winter bird-population study: 18. City park, lagoon, harbor, and lake. Audubon Field Notes 14(3):352-353.

.1961. Winter bird-population study: 26. City park, lagoon, harbor, and lake. Audubon Field Notes 15(3):371

— City park, lagoon, harbor, and lake. Audubon Field Notes 16(3):374.

Guth, R.W. 1979. The junk food guild: birds and mammals on picnic grounds and in residential areas. Illinois Audubon Bulletin 189:3-7.

Hall, W. 1930. The mid-winter survey: Athens. Audubon Bulletin 20:23-25.

- 1931. Notes from Athens, Illinois. Audubon Bulletin 2 1:37.

Hamilton, J.L. 1968. Winter survey: December Ist through February 29 th. Bluebird $35(2-3): 3-8$.

Hancock, J.L. 1888. The relative weight of the brain to the body in birds. American Naturalist 22(258):537-539.

Hardy, J.W. 1961. Studies in behavior and phylogeny of certain New World jays (Garrulinae). University of Kansas Science Bulletin 42(2), $149 \mathrm{p}$.

Hess, I.E. 1910. One hundred breeding birds of an Illinois ten-mile radius. Auk 27(1):19-32.

- 1913. Isaac Hess's bird talks. Decatur Daily Herald, 26 October 1913.

_. 1917. A challenge. Audubon Bulletin, spring:36.

Hickey, J.J. 1952. Survival studies of banded birds. U.S. Department of the Interior, Fish and Wildlife Service Special Scientific Report: Wildlife 15. $177 \mathrm{p}$.

Higgins, H., Mrs. 1946. Banded blue jay recovered after years. Passenger Pigeon 8:88.

Hodges, J. 1949. The blue jay as a predator. Iowa Bird Life 19(2): 34.

1951. The breeding birds of Credit Island. Iowa Bird Life $21(3): 50-51$

1954. The Burtis H. Wilson journals. Iowa Bird Life 24(2): $34-38$.

Holcombe, C.E., and C.E. Ycomans. 1939. Illinois. Inland Bird Banding News 10(3):8-9.

Hopkins, E.M. 1974. Thirty-eighth breeding bird census: 42. Poorly drained mixed oak forest. American Birds 28(6): 1008 .

1978. Forty-first breeding bird census: 41. Poorly drained mixed oak forest. American Birds 32(1):67.

Hulsberg, E. 1917-1918. Notes from LaGrange. Audubon Bulletin, winter: 31 .

Jackson, A.W. 1905. Notes on winter feeding from Jacksonville, Illinois. Bird-Lore 7(5):243-244.

Johnston, D.W. 1961. The biosystematics of American crows. University of Washington Press, Seattle. 119 p.

foliet Audubon Socicty. 1949. Forty-ninth Christmas bird count: 240. Joliet, III. Audubon Field Notes 3(2):115.

Jones, D. 1934. Our robins. Iowa Bird Life $4(4): 50$,

lones, S. 1934. The season: St. Louis region. Bird-Lore 36(3): 185186.

Jurica, E. 1961. 1960 station returns-Lislc, Illinois, Inland Bird Banding News 33(3):34.

_. V. Laketek, and J. Spoden. 1962. 1961 station returnsLisle, Illinois. Inland Bird Banding News 34(3):39. 
Kalmbach, E.R. 1915. Winter crow roosts. Pages 83-100 in U.S. Department of Agriculture Yearbook.

…. 1918. The crow and its relations to man. U.S. Department of Agriculture Bulletin 621.92 p.

Karr, J.R. 1968. Habitat and avian diversity on strip-mined land in east-central Illinois. Condor 70(4):348-357.

Keener, V. 1981. Forty-fourth breeding bird census: 41. Riparian oak-hickory forest. American Birds 35(1):60.

Kendeigh, S.C. 1982. Bird populations in east central Illinois: fluctuations, variations, and development over a half-century. IIlinois Biological Monographs 52. $136 \mathrm{p}$.

Kennicott, R. 1853-1854. Catalogue of animals observed in Cook County, Illinois. Illinois State Agricultural Society Transactions 1:577-595.

Kirby, R., and G. Chaniot, Jr. 1957. Winter bird-population study: 16. Grazed stream bottomland. Audubon Field Notes 1 (1):301.

Kleen, V.M. 1974a. The fall migration August l-November 30, 1973: middlewestern prairie region. American Birds 28(1):5863.

_ 1974b. The winter season December 1, 1973-March 31, 1974: middlewestern prairie region. American Birds 28(3): $645-649$.

- 1976. The fall migration August 1-November 30, 1975: middlewestern prairie region. American Birds 30(1):77-82.

- 1977. Field notes: fall migration. Illinois Audubon Bulletin 180:36-46

1978a. Field notes: spring migration. Illinois Audubon Bulletin 186:27-39.

1978b. The winter season December 1, 1977-February 28, 1978: middlewestern prairie region. American Birds 32(3): $357-361$.

-1979. Field notes: winter season. Illinois Audubon Bulletin 189:18-22.

-1980. Field notes: winter season. Illinois Audubon Bulletin 193:25-30.

-1981a. Field notes: fall migration. Illinois Audubon Bulletin 196:36-52.

$1981 \mathrm{~b}$. Field notes: winter season. Illinois Audubon Bulletin 197:28-39.

-1981c. Fall migration. Illinois Department of Conservation Seasonal Report 31. 24 p.

- 1982a. Field notes: the 1981/82 winter season. Illinois Audubon Bulletin 201:39-48.

1982b. Field notes: spring migration. Illinois Audubon Bulletin 202:34-54.

- 1982-1983. Winter season. Illinois Department of Conservation Seasonal Report 36. 12 p.

-1983-1984. Field notes: breeding season. Illinois Audubon Bulletin 207:39-45.

1984. Report and results: '84 statewide spring bird count. Illinois Audubon Bulletin 210:21-29.

_ and L. Bush. 1972. The spring migration April 1 to May 31, 1972: middlewestern prairie region. American Birds 26(4): $765-769$.

Labahn, F.C. 1932. March 19, 1932 in N.E. Illinois. Oologist 49(4):41.

1941. Banding at Blue Island, Illinois. Inland Bird Banding News $13(2): 17-18$.

Le Baron, W. 1853-1854. Observations upon some of the birds of Illinois most interesting to the agriculturist. Illinois State Agricultural Society Transactions 1:559-565.

Lehmann, M.C. 1959. Fifty-ninth Christmas bird count: 354 . Waukegan, Ill. Audubon Field Notes 13(2): 190.

-1961. Sixty-first Christmas bird count: 383 . Waukegan, III. Audubon Field Notes 15(2):215.
Lincoln, F.C. 1927. Returns from banded birds 1923-1926. U.S Department of Agriculture Technical Bulletin $32.95 \mathrm{p}$.

- 1939. The migration of American birds. Doubleday Doran and Co., Inc., New York. 189 p.

Lussenhop, J. 1977. Urban cemeteries as bird refuges. Condor $79(4): 456-461$.

Lyon, W.I. 1922. Characters and dispositions II. Audubon Bulletin, fall: $16-18$

53.

- 1933. Bird banding dates, fall 1932. Inland Bird Banding News 5(2):5-6.

- 1934. Illinois. Inland Bird Banding News 6(4):5.

Maxwell, H.A. 1921. Records, regular and periodic. Audubon Bulletin, fall:6.

McClellan, J.F. 1948. Observations on Plasmodium of birds from the vicinity of Urbana, Illinois. M.S. Thesis. University of Illinois. $37 \mathrm{p}$.

Mengel, R.M. 1965. The birds of Kentucky. American Ornithologists' Union Ornithological Monographs 3.581 p.

Miller, D.E., and W.B. Miller. 1972. Twenty-fifth bird-population study: 54. Suburban woodlot. American Birds 26(3):686-687.

Montague, A.C. 1950. Winter bird-population study: 12. Bottomland deciduous forest. Audubon Field Notes 4(3):225-226.

1951. Winter bird-population study: 19. Bottomland deciduous forest. Audubon Field Notes 5(3):238.

1952. Winter bird-population study: 27 . Bottomland deciduous forest. Audubon Field Notes 6(3):227.

- 1953. Winter bird-population study: 21. Bottomland deciduous forest. Audubon Field Notes 7(3):246.

Montgomery, A.E. 1956. Bird mortality in Elmhurst. Audubon Bulletin 99:1-3.

Mooney, J.J. 1930. Oology from Deerfield, Ill. Oologist 47(7):81.

Morrison, M.D. 1978a. Thirtieth winter bird-population study: 16. Upland deciduous forest. American Birds 32(1):28.

- 1978b. Forty-first breeding bird census: 39 . Upland deciduous forest. American Birds 32(1):66-67.

- and B. Peterjohn. 1977. Fortieth breeding bird census: 42 . Upland deciduous forest. American Birds $31(1): 44$.

Mumford, R.E. 1959. Regional reports, winter season December 1, 1958-March 31, 1959: middlewestern prairie region. Audubon Field Notes 13(3):295-298.

Murchison, A.C. 1892. The long-eared owl. Oologist 9(8): 199-201.

Musselman, T.E. 1913. A comparative study of bird migration in Illinois along the 40 th parallel of latitude. M.A. Thesis. University of Illinois. $74 \mathrm{p}$.

1921a. A history of the birds of Illinois. Illinois State Historical Society Journal 14(1):1-73.

1921b. Notes from the field: Quincy, Audubon Bulletin, spring: 40 .

․ 1934-1935. 1934 nature diary. Audubon Bulletin 2425:27-34.

- 1936. 1935 nature diary. Audubon Bulletin 26:24-29.

Nehrling, H. 1883. Beiträge zur Ornis des nördlichen Illinois. Journal für Ornithologie 31:84-97.

Nelson, E,W. 1876. Birds of north-eastern Illinois. Essex Institute Bulletin 8(9-12):90-155.

- 1877. Notes upon birds observed in southern Illinois, between July 17 and September 4, 1875. Essex Institute Bulletin $9(1,2,3): 32-65$.

Nolan, V., Jr. 1958. Regional reports, spring migration April I to May 31, 1958: middlewestern prairie region. Audubon Field Notes 12(4):356-358.

Oberholser, H.C. 1918. The migration of North American birds: magpies. Bird-Lore 20(6):415. 
1921. The geographic races of Cyanocitta cristata. Auk $38(1): 83-89$.

Parmalee, P.W. 1949. An analysis of development and behavior of the young crow. M.S. Thesis. University of Illinois. $62 \mathrm{p}$.

1952. Growth and development of the nestling crow. American Midland Naturalist 47(1):183-201,

1957. Vertebrate remains from the Cahokia Site, Illinois. Illinois State Academy of Science Transactions 50:235-242.

1958. Remains of rare and extinct birds from Illinois Indian sites. Auk 75(2): 169-176.

- 1962. Additional faunal records from the Kingston Lake Site, Illinois. Illinois State Academy of Science Iransactions $55(1): 6-12$.

1964. Vertebrate remains from an historic archeological site in Rock Island County, Illinois. Illinois State Academy of Science Transactions 57(3):167-174.

-1967. Additional noteworthy records of birds from archeological sites. Wilson Bulletin 79(2):155-162.

1968. Cave and archeological faunal deposits as indicators of post-Pleistocene animal populations and distribution in IIlinois. Pages 104-113 in R. E. Bergstrom, ed. The quartenary in Illinois: a symposium in observance of the centennial of the University of Illinois. University of Illinois College of Agriculture Special Publication 14.

_ and A.E. Bogan. 1980. A summary of the animal remains from the Noble-Wieting Site (11ML28), McLean County, IIlinois. Illinois Academy of Science Transactions 73(4): 1-6.

—, A.A. Paloumpis, and N. Wilson. 1972. Animals utilized by Woodland peoples occupying the Apple Creek Site, Illinois. Illinois State Museum Reports of Investigations 23.62 p.

Peterjohn, B.G. 1981. Continental survey, the winter season December 1, 1980-February 28, 1981: middlewestern prairie region. American Birds 35(3):304-307.

1983. Continental survey, the spring migration March 1May 31, 1983: middlewestern prairie region. American Birds $37(5): 874-878$.

1985. Continental survey, the autumn migration August 1-November 30, 1984: middlewestern prairie region. American Birds 39(1):59-63.

Pinowski, J., and S.C. Kendeigh, eds. 1977. Granivorus birds in ecosystems: their evolution, populations, energetics, adaptations, impact, and control. International Biological Programme 12. Cambridge University Press, Cambridge, England; New York, $431 \mathrm{p}$.

Pitelka, F.A. 1946. Age in relation to migration in the blue jay. Auk $63(1): 82-84$

Prager, R.G. 1976. A sampling of Forest Park birds. Peoria Park District, Peoria, Illinois. 24 p.

Pratt, G.B. 1907. Notes from field and study: the blue jay as a destroyer. Bird-Lore 9(2):82-83.

Princen, L.H. 1970. Unusual bird sightings in central Illinois during 1969. Peoria Academy of Science Proceedings 3:24-27.

Ridgway, R. 1873. The prairie birds of southern Illinois. American Naturalist 7(4):197-203

- 1874. On local variations in the notes and nesting habits of birds. American Naturalist 8(4): 197-201

- 1878. Notes on birds observed at Moune Carmel, southern Illinois, in the spring of 1878. Nuttall Ornithological Club Bulletin 3(4): 162-166.

1904. The birds of North and Middle America. U.S. Na. tional Museum Bulletin 50, part 3.801 p.

-1913. The ornithology of Illinois. Vol. 1. Illinois Natural History Survey. Pantagraph Printing Co., Bloomington, III. 520 p. [First published in 1889.]

. 1920. Notes from Bird Haven, Olney, Illinois. Audubon Bulletin, fall:20.
1925. 'The birds of 'Larchmound'-a résumé. Bird-1ore 27(5):305-309.

Riegel, R., and D. Varland. 1978. Thirtieth winter bird-population study: 18. Floodplain forest 1. 19. Floodplain forest II. American Birds 32(1):29.

Riis, P.B. 1921. Notes from the field: Rockford. Audubon Bulletin, spring:40-41,

Ritter, P.J. 1909. Blue jay boarders. Bird-Lore 1 I(5):212-213.

Robbins, M. 1979. Fall survey: August I through November 30 , 1978. Bluebird 46(1):21-28.

Roberts, G., Jr. 1918. Notes from field and study: observations on a food-shelf. Bird-Lore 20(6):423-426.

1919. Mid-winter field notes. Audubon Bulletin, winter 1918-1919:41-42.

1920. Mid-winter notes 1919-1920: Lake Forest. Audubon Bulletin, spring:42.

ㄴ. 1922. Seven years of a food shelf. Audubon Bulletin, spring:7-9.

Robertson, M.J. 1959. Analysis of breeding-bird populations at AIlerton Park, central 1llinois, 1946-1955. M.S. Thesis. University of Illinois. $114 \mathrm{p}$.

Robertson, W. 1941a. Audubon Magazine's fifth breeding-bird census: 9. Swampy prairie. Audubon Magazine 43(5):485 (Section 2).

- 1941b. Audubon Magazine's fifth breeding-bird census: 33. Cut-over upland forest with pond. Audubon Magazine 43(5):496-497 (Section 2).

- 1942a. Audubon Magazine's sixth breeding-bird census: 5 . Swampy prairie. Audubon Magazine 44(5): 18-19 (Section 2). 1942b. Audubon Magazine's sixth breeding-bird census: 22. Cut-over upland oak-hickory forest with pond. Audubon Magazine 44(5):27 (Section 2).

-1944a. Audubon Magazine's eighth breeding-bird census: 5 . Swampy prairie. Audubon Magazine 46(5): 16 (Section 2).

- 1944b. Audubon Magazine's eighth breeding-bird census: 14. Upland oak-hickory forest with pond. Audubon Magazine 46(5): 19 (Section 2).

Robertson, W. B., and D. Snyder. 1948. Twelfth breeding-bird census: 11. Cut-over upland oak-hickory forest. Audubon Field Notes 2(6):233.

Roseberry, J.L. 1962. Avian mortality in southern Illinois resulting from severe weather conditions. Ecology 43(4):739-740.

Russell, R.P., Jr. 1967. Is your latest sighting on the 'hypothetical' list? Audubon Bulletin 144:11-15.

Sachs, I.B. 1948. On certain blood-inhabiting protozoa observed in birds in the vicinity of Urbana, Illinois. M.S. Thesis. University of Illinois. $41 \mathrm{p}$.

Sanborn, C.C. 1911. Notes from northern Illinois. Oologist $28(11): 180$.

- 1922. Chicago winter birds. Field Museum of Natural History, Department of Zoology, Leaflet 2. 11 p.

- and W.A. Goclitz. 1915. A two-year nesting record in Lake County, III. Wilson Bulletin 27(4):434-448.

Schafer, J.J. 1917. Winter notes: winter birds on a Rock Island County farm. Audubon Bulletin, spring:55-56.

Schantz, O.M. 1922. The mockingbird as a northern visitor. Audubon Bulletin, spring:21.

Segal, S. 1960. Bird tragedy at the dunes. Indiana Audubon Quaricrly $38(2): 23-25$

Shackleford, M.W. 1929. Animal communities of an Illinois prairic. Ecology 10(1):126-154

Shaw, A., and J. Shaw. 1983. The cighty-third Audubon Christmas bird count: 927. Hannibal, Mo. American Birds 37(4):637.

Shaw, V.S. 1958. Winter bird-population study: 13. Shrubby ficld and lake. Audubon Field Notes 12(3):312-313.

1959. Winter bird-population study: 18. Shrubby field and lake. Audulon Ficld Notes 13(3):336 
1960. Winter bird-population study: 20. Shrubby field and lake. Audubon Field Notes 14(3):353.

1961. Winter bird-population study: 25. Shrubby field and lake. Audubon Field Notes 15(3):371.

-1962. Winter bird-population study: 17. Shrubby field and lake. Audubon Field Notes 16(3):374.

1963. Winter bird-population study: 18. Shrubby field and lake. Audubon Field Notes 17(3):371.

1964. Winter bird-population study: 29. Shrubby field and lake. Audubon Field Notes 18(3):410.

-... T. Axelson, M. Hundley, C. Scherer, and R. Thom, Jr. 1965. Winter bird-population study: 19. Shrubby field and lake. Audubon Field Notes 19(3):427.

- M. Hundley, and C. Scherer. 1968. Winter bird-population study: 26. Shrubby field and lake. Audubon Field Notes 22(3):492.

- C. Scherer, W. Bridges, and M. Hundley. 1956. Winter bird-population study: 25. Shrubby field and forest edge. Audubon Field Notes 10(3):297.

- and P.M. Stine. 1955. Winter bird-population study: 29. Shrubby field and forest edge. Audubon Field Notes 9(3):304.

Silloway, P.M. 1894, A pair of Bubos at home. Oologist 11(5): 179181 .

1906a. A novice's notebook-No. 4. Oologist 23(6):89-91. 1906b. A novice's notebook-No. 6. Oologist 23(10):155156.

Snyder, D., C. Bonney, and W.B. Robertson. 1948. Twelfth breeding-bird census: 15. Deciduous flood-plain forest. Audubon Field Notes 2(6):237.

Southern, W.E. 1966. Utilization of shad as winter food by birds. Auk 83(2):309-311.

Starrett, W.C. 1938. Highway casualties in central Illinois during 1937. Wilson Bulletin 50(3): 193-196.

Stocking, M.K. 1974. A decade of banding in Beloit, Wisconsin. Inland Bird Banding News 46(4): 123-136.

Stoddard, H.L. 1920. Mid-winter notes 1919-1920: Chicago area. Audubon Bulletin, spring:36-38.

Stoner, D. 1929. Trapping and banding birds at Iowa City during 1927. Iowa Academy of Science Proceedings 36:373-375

Strode, W.S. 1887. Notes ornithological and otherwise from Spoon River region, Illinois. Oologist 4(2):71-72.

1889a. Among the raptores. Wilson Bulletin 1(1):19-21.

$1889 \mathrm{~b}$. The dark side of collecting. Ornithologist and Oologist 14(12): 177-179.

- 1894. Screech owl and blue jay. Nidologist 1(5):76.

Swink, F. 1976. A finding list of the birds of the Morton Arboretum. Morton Arboretum, Lisle, Ill. 43 p.
Taber, W.B., Jr. 1927. The mentality of the crow. Wilson Bulletin 39(1):5-8.

Thomas, C. 1882. Eleventh report of the state entomologist on the noxious and beneficial insects of the state of Illinois. H.W. Rokker, Springfield, III. 104 p.

Thompson, M.D. 1960. The 1959 nesting report. Audubon Bulletin 115:7-13.

Twomey, A.C. 1945. The bird population of an elm-maple forest with special reference to aspection, territorialism, and coactions. Ecological Monographs 15(2):173-205.

U.S. Biological Survey. 1937-1938. Banding returns. U.S.Department of Agriculture.

Van Duzer, J.C. 1916. Spring census and migration records for 1916: Rockford. Audubon Bulletin, spring:44-46.

Walker, I. 1924. A teacher's experience. Bird-Lore 26(3):213-214.

Warner, R.E. 1982. [untitled]. Monthly Wildlife Research Letter, Illinois Natural History Survey 25(10): 1-2.

Watson, J.D., and M. DeLaubenfels. 1917. Spring census and migration record: LaGrange. Audubon Bulletin, spring:48-49.

Weiland, E.C. 1960. Station returns at Marquette, Michigan. Inland Bird Banding News 32(1):8.

Weise, C.M. 1951. Breeding populations and reproductive success of birds of the forest and forest-edge in central Illinois. M.S. Thesis. University of Illinois. $123 \mathrm{p}$.

Wheat, T. 1886. Correspondence. Ornithologist and Oologist 11(5):80.

Widmann, O. 1880. Notes on birds of St. Louis, Mo. Nuttall Ornithological Club Bulletin 5(3): 191-192.

-1888. The crows' winter roost at St. Louis. Ornithologist and Oologist 13(2):17-19.

-1898. The great roosts on Gabberet Island, opposite North St. Louis, Mo. Auk 15(1):22-27.

1907. A preliminary catalog of the birds of Missouri. Academy of Science of St. Louis Transactions 17(1). 288 p.

- 1922. Extracts from the diary of Otto Widmann: our birds in winter. Academy of Science of St. Louis Transactions 24(8):24-48.

Wilson, J.D. 1982. Winter survey. Bluebird 49(2): 14-18.

Woodruff, F.M. 1896. General notes: the raven in Illinois. Auk $13(1): 83-84$.

1907. The birds of the Chicago area. Chicago Academy of Sciences Natural History Survey Bulletin 6. 221 p.

1912. General notes: two interesting captures in Lincoln Park, Chicago. Auk 29(1):109.

Wright, J.S. 1897. Notes on crow roosts of western Indiana and eastern Illinois. Indiana Academy of Science Proceedings 1897:178-180.

Yeomans, C. 1950. Note. Inland Bird Banding News 22(5):28. 
High quality manuseripts dealing with any aspect of natural history will be considered for public ation in one af the tllinois Nitutal

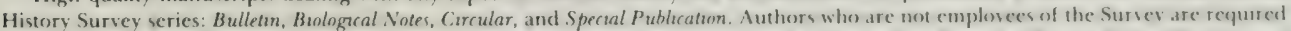

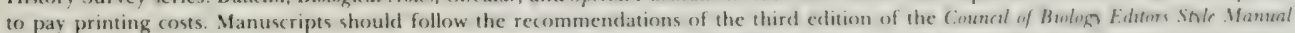
except that journal names in the literature cited section are to be spelled in full. The Survev expects to publish only one or two manuseripes by non-Survey authors yearly.

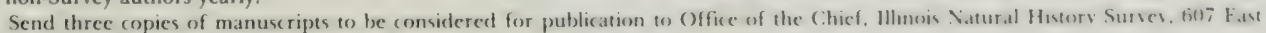
Peabody Drive, Champaign, Illinois 61820.

\section{Citation:}

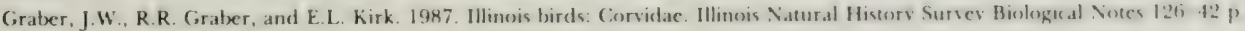


Printed by authority of the State of Illinois 


